\title{
Evaluation of UFP Number Concentrations Near a Natural Gas Transmissions Station
}

John M. Thornsbury

West Virginia University, jmt0035@mix.wvu.edu

Follow this and additional works at: https://researchrepository.wvu.edu/etd

Part of the Environmental Health and Protection Commons

\section{Recommended Citation}

Thornsbury, John M., "Evaluation of UFP Number Concentrations Near a Natural Gas Transmissions Station" (2019). Graduate Theses, Dissertations, and Problem Reports. 3927.

https://researchrepository.wvu.edu/etd/3927

This Thesis is protected by copyright and/or related rights. It has been brought to you by the The Research Repository @ WVU with permission from the rights-holder(s). You are free to use this Thesis in any way that is permitted by the copyright and related rights legislation that applies to your use. For other uses you must obtain permission from the rights-holder(s) directly, unless additional rights are indicated by a Creative Commons license in the record and/ or on the work itself. This Thesis has been accepted for inclusion in WVU Graduate Theses, Dissertations, and Problem Reports collection by an authorized administrator of The Research Repository @ WVU. For more information, please contact researchrepository@mail.wvu.edu. 


\title{
Evaluation of UFP Number Concentrations Near a Natural Gas Transmission Station
}

\author{
John M. Thornsbury
}

Thesis submitted to The Statler College of Engineering and Mineral Resources at West Virginia University

in partial fulfillment of requirements for the degree of

Master of Science in

Industrial Hygiene

\author{
Xinjian He, Ph.D., Chair \\ Michael McCawley, Ph.D. \\ Gary Winn, Ph.D. \\ Department of Industrial and Management Systems Engineering
}

Morgantown,WV

2019

Keywords: Ultrafine Particles

Copyright 2019, John Thornsbury 


\section{Abstract \\ Evaluation of UFP Number Concentrations Near a Natural Gas Transmission Station}

\section{John M. Thornsbury}

Identifying UFP number concentrations near a natural gas compressor station is key to understanding ambient exposures associated with the transmission station. Developing an atmospheric survey to characterize these concentrations was key in understanding ambient exposures. The aims of this study are to compare and contrast number concentrations taken in a hollow, near the transmission station to those of the background. From this, it would be possible to identify whether or not the compressor station was a contributing factor to peaks and spikes in number concentrations.

This study begins with a review of what UFPs are, how they react in different atmospheres, and their health effects. Objectives of the study are then described in detail. This is followed by a brief discussion on the sampling procedure and protocols used during the sampling process. Further sections cover the results of the 14 days of sampling, and conclusions about the sampling days. The study concludes with a summary of limitations and why further research is required. 


\section{Acknowledgments}

This study was conducted in conjunction with the West Virginia University School of Engineering. For his knowledge, support, and guidance I must thank Dr. Michael McCawley, who lent his expertise and knowledge to myself and many other Industrial Hygienists.

Furthermore, this study would not have been possible without Jim McIntosh, who molded a young safety professional and helped him realize his dream in the field. 


\section{List of Figures}

Figure 1: Toxicity Mechanisms of UFPs

Figure 2: Emissions with a Normal Thermal Gradient List of Tables

Figure 3: Temperature Inversion

Figure 4: TSI P Trak Model 8525

Figure 5: Oregon Scientific WMR 200 Weather Station

Figure 6: Working Diagram of P-Trak

Figure 7: Sampling Locations and Sampling Stations

\section{List of Tables}

Table 1: Difference in Distance and Elevation between each Sampling Location

Table 2: Number Concentration Comparison Between P-Traks

Table 3: Number Concentrations Between Station One and Two

Table 4: Summary of Weather Data

Table 5: Paired T-Test

Table 6: Regression Analysis

Table 7: ANOVA

Table 8: Atmospheric Stability Classification

Table 9: Atmospheric Stability for September 20th

Table 10: Statistical Significance of Weather Conditions Vs. Number Concentrations Vs. Inversions 
Table 11: Morning Traffic Rates

Table of Contents

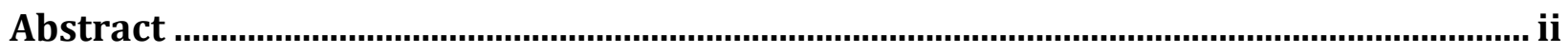

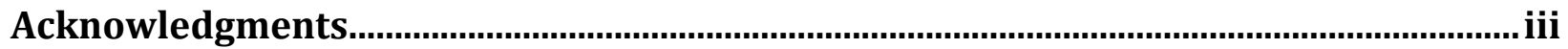

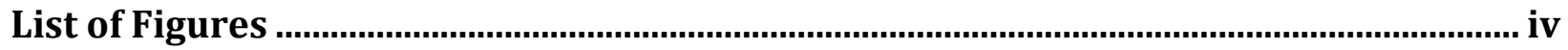

List of Tables .............................................................................................................................. iv

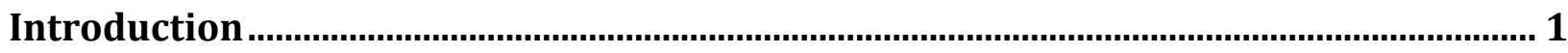

Chapter 2: Literature Review ................................................................................................. 2

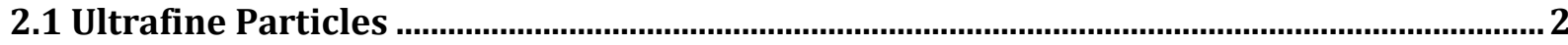

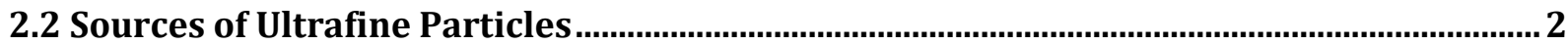

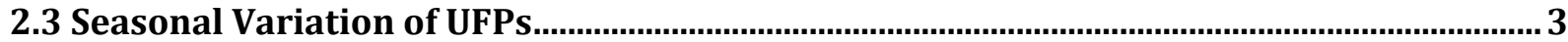

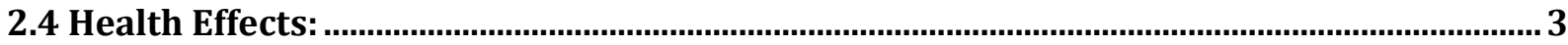

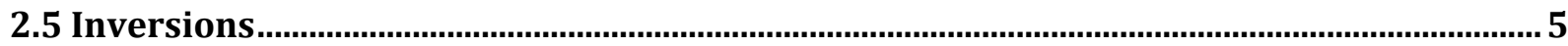

2.6 Natural Gas Transmission and Compressor Stations ......................................................... 7

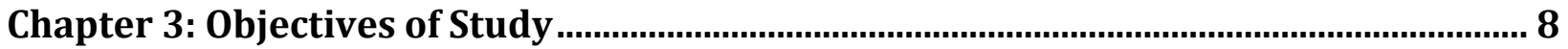

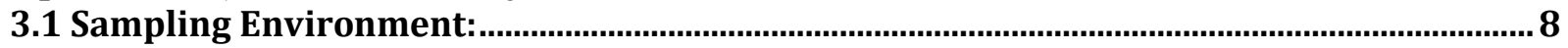

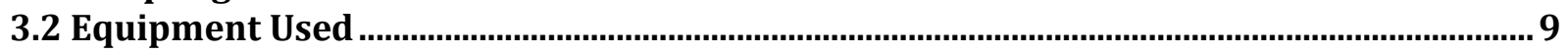

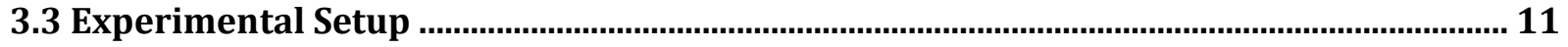

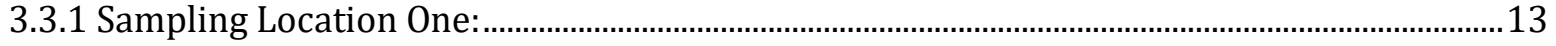

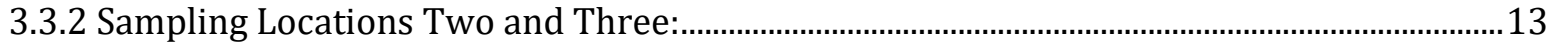

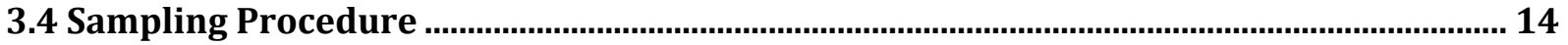

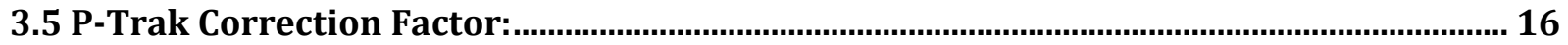

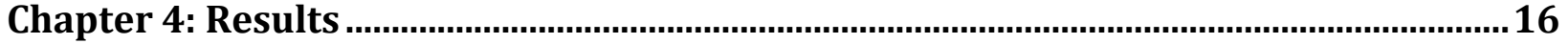

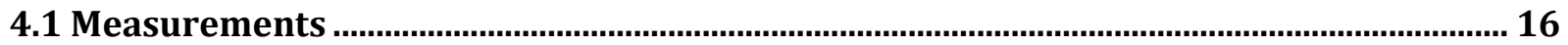

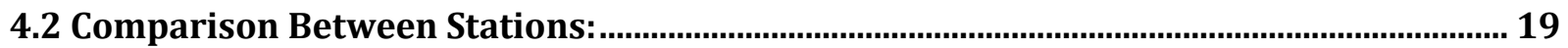

4.3 Comparing Weather Conditions to Station 2 Concentrations: .............................................. 20

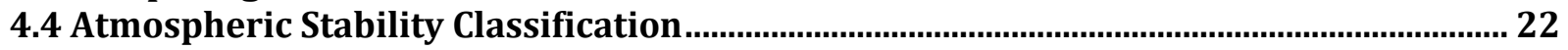

Chapter 5: Discussions and Conclusions............................................................................... 25

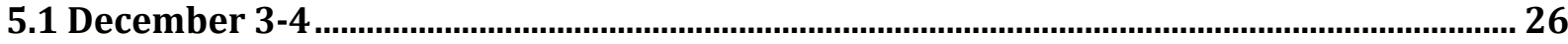

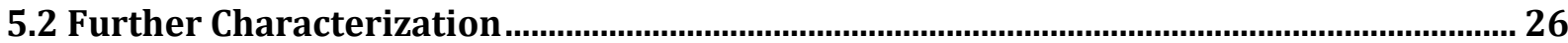

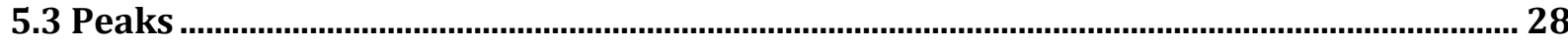

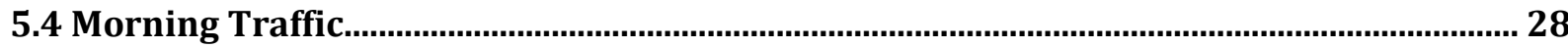

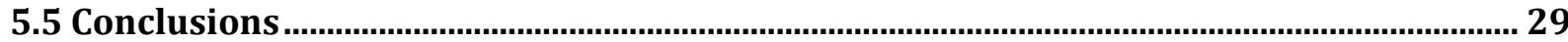

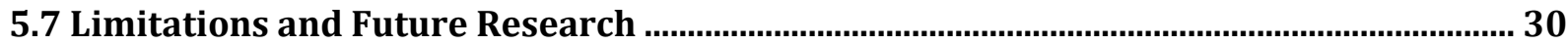

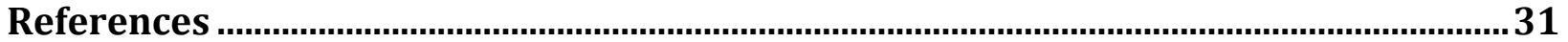

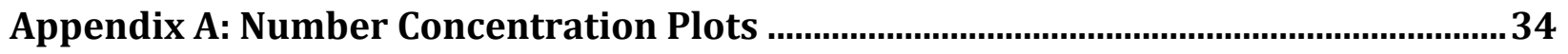

Appendix B: Atmospheric Stability ...................................................................................41

Appendix C: Number Concentrations for each Days Sampling ..................................52 


\section{Introduction}

Ultrafine particles (UFPs) are ubiquitous in air. Due to their small size and nature, UFPs are linked to adverse human health effects. It has been shown that UFPs are most commonly associated with two different types of sources, mobile and stationary (Posner \& Pandis, 2015). These sources of UFPs are commonly characterized by their number concentration or $(\mathrm{PT} / \mathrm{cc})$.

Many studies tend to look at UFP number concentrations near urban environments. The reason for this is due to the larger number of vehicles and stationary sources in a smaller area. As pointed out, concentrations in street canyons can show number concentrations several times higher than unobstructed areas (Kumar, Matthias, Vardoulakis, Pirjola, \& Britter, 2011).

Chapter 3 of this study details the process by which the study was conducted. Number concentrations were taken in a hollow and on the top of a mountain. This was completed as to be able to characterize what ambient number concentrations near a natural gas transmission station were. Since no literature on this subject can be found, it was clear that a gap in research is present.

Furthermore, this study looks at how different atmospheric conditions and cofounding factors were associated to the number concentrations in the hollow. This was 
completed by establishing different sampling locations and comparing number concentrations to wind speed, wind direction, and temperature. From this, a regression analysis could be completed to determine the relationship between the atmospheric conditions and number concentrations near a compressor station. Number concentrations can vary depending on where and when the observation is made (Solomon). UFP concentrations can also vary among day and season as shown in the study.

After correlations with wind speed, wind direction, and temperature were established, atmospheric stability was studied to be able to see when and if inversions had occurred during the sampling period. As represented below, inversions are sometimes associated with increase in number concentrations.

\section{Chapter 2: Literature Review}

\subsection{Ultrafine Particles}

What are ultrafine particles? Ultrafine particles can be defined as liquid particles, dry particles, or combinations with an aerodynamic diameter smaller than 0.1 microns. (Donaldson, Stone, Renwick, \& MacNee, 2001). Due to their small size, UFPs have been shown to penetrate deeply into the lungs, leading to the potential for adverse health effects (Clifford, et al., 2018).

\subsection{Sources of Ultrafine Particles}

Sources of ultrafine particles can be broken down into two major categories, automobiles (both gasoline and diesel) and industrial sources. Although vehicle emissions 
account for approximately $40 \%$ of UFP emissions, stationary industrial sources are at a close second with 33\% of emissions. (Posner \& Pandis, 2015).

Number concentrations from these industrial sources and vehicles tend to be concentrated highest during the initial emission of the particle. The processes that are seen during this period are condensation/evaporation, coagulation, and new particle formation (Morawska, Ristovski, Jayaratne, Keogh, \& Ling, 2008).

\subsection{Seasonal Variation of UFPs}

Seasonal trends can be observed when evaluating UFP concentrations (Pirjola, et al., 2006). These trends can be associated with a number of factors. In the winter we tend to see higher concentrations due to atmospheric stability. One study showed that particle concentrations were two to three times higher in Finland during the winter months (Virtanen, et al., 2006). Another study in Pittsburgh found the highest average number concentrations in December and lowest in July (Zhang \& Wexler, 2015)

\subsection{Health Effects:}

When considering exposure routes, literature points to inhalation as being the primary exposure route for UFPs from air pollution (Chen, et al., 2016). One could go on to further state that due to their small size UFPs are more dangerous than bigger particles, such as PM2.5 and PM10. Since we tend to see increased number concentrations with UFPs, the decreased particle size and increased surface area boost biological activity (Rinaldo, et al., 2015). 
Due to their small size and large surface area, routs of exposure may consist of ocular, dermal, and respiratory exposure. For this study we will focus on respiratory exposures. As with most inhalation exposures, we are primarily concerned with the airways and the alveolar region of deposition. Semmler, et al showed that due to the nature of UFPs, the body does not have a mechanism to clear UFPs after they have reached the alveolar region (Semmler, et al., 2004). High deposition and low clearance lead to accumulation in the alveolar region (Chen, et al., 2016). Another concern when considering UFPs is their ability to pass through the blood gas barrier. UFPs have the ability to do this by passing through the epithelial cell body (Thorley, Ruenraroengsak, Potter, \& Tetley, 2014). For such reasons, UFPs can be described as more toxic and inflammatory due to their nature and small size. Figure 1 below will help one visualize toxicity mechanisms of UFP pollution. 


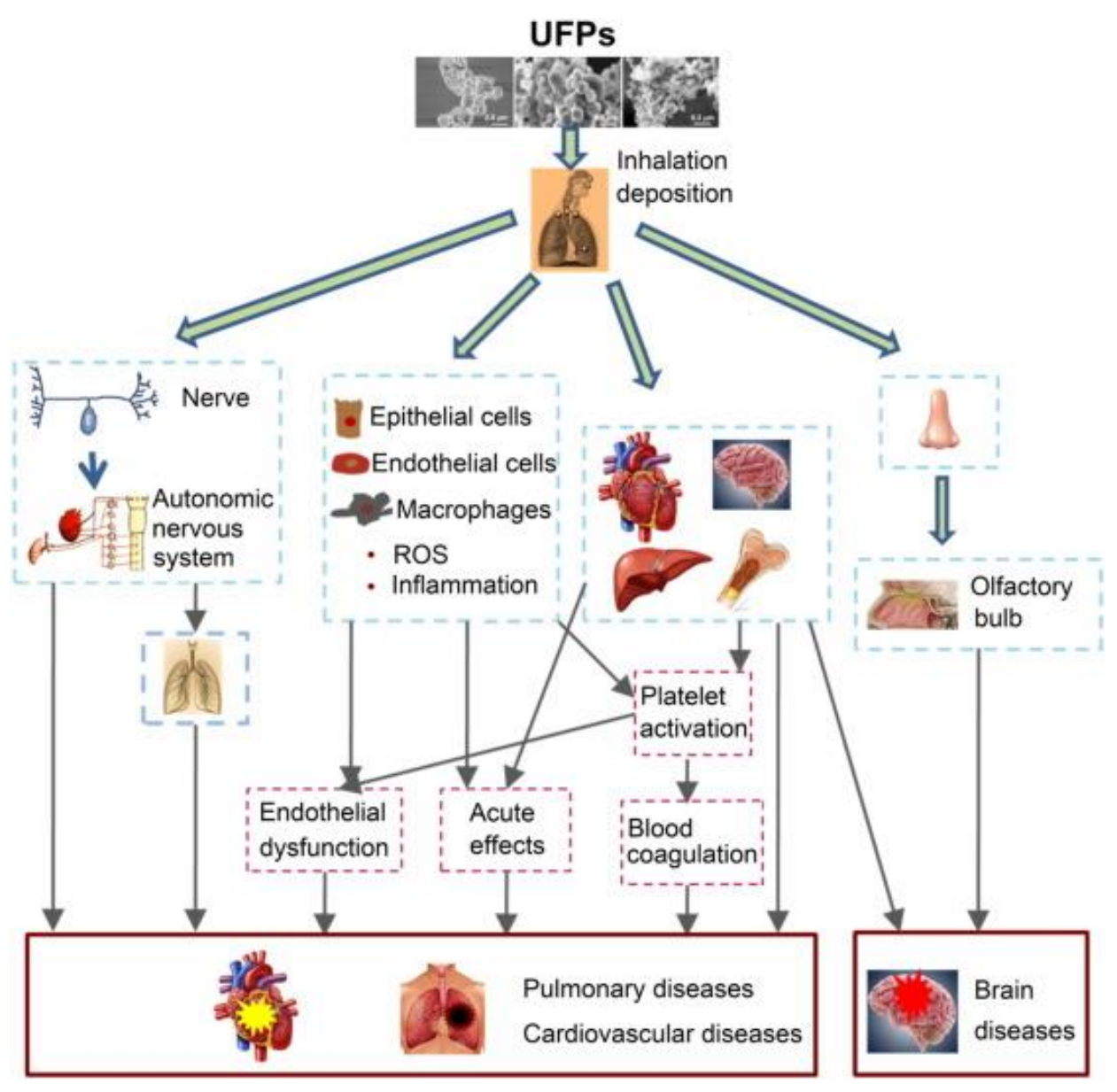

Figure 1: Toxicity Mechanisms of UFPs (Chen, et al., 2016).

\subsection{Inversions}

There are several types of inversions. For the purposes of this study we will focus on ground inversions. A ground inversion occurs when air is cooled by contact with another surface until it becomes cooler than the overlying atmosphere. Furthermore, when the topography consists of mountains or hills, the cold air tends to sink into the hollows producing large inversions above ground and little to no inversions above higher ground (Britannica, 2016). 
Under normal weather conditions, where the thermal gradient is normal, we tend to see emissions rise until they reach equilibrium with the surrounding atmosphere. When a surface inversion occurs, especially in a hollow, we tend to see emissions held closer to the source. When atmospheric conditions are stable and an inversion occurs, a layer of cooler dense air lies near the ground. This cooler air prevents emissions from dispersing up into the atmosphere and reaching equilibrium.

The two diagrams below visually illustrate the ground inversion principle. Figure 2 describes how emissions act during a normal thermal gradient. Figure 3 details the temperature inversion.

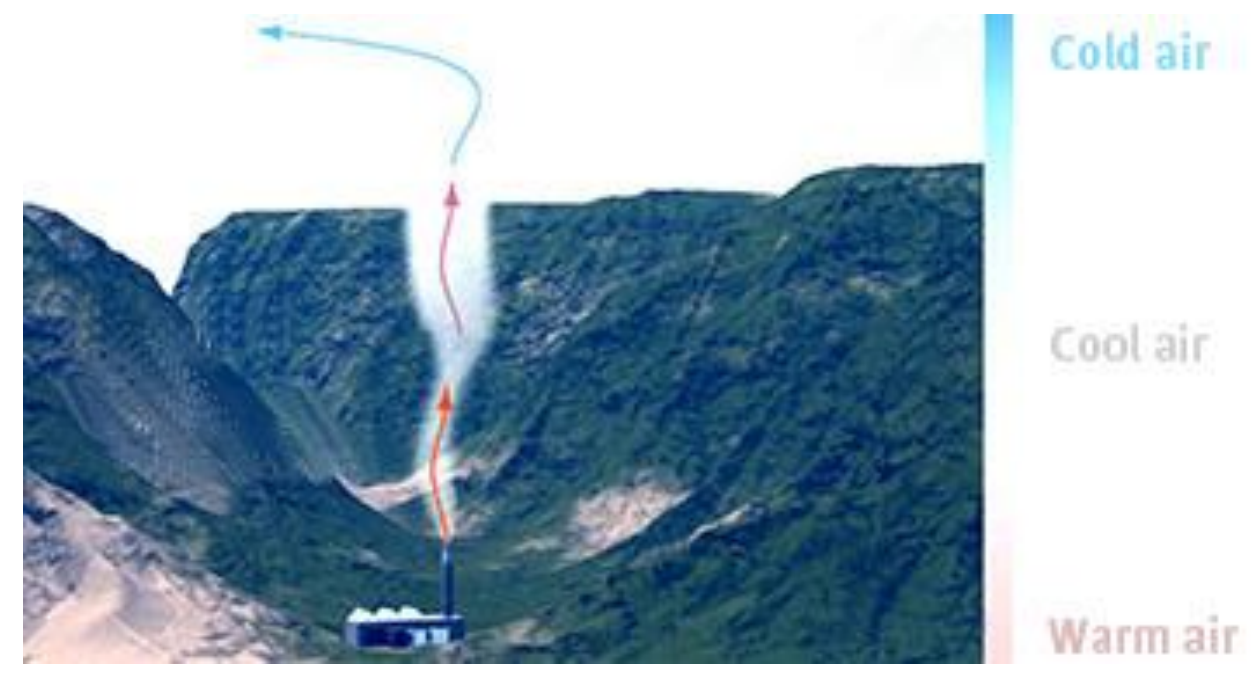

Figure 2: Emissions with a Normal Thermal Gradient (Queensland, 2013) 

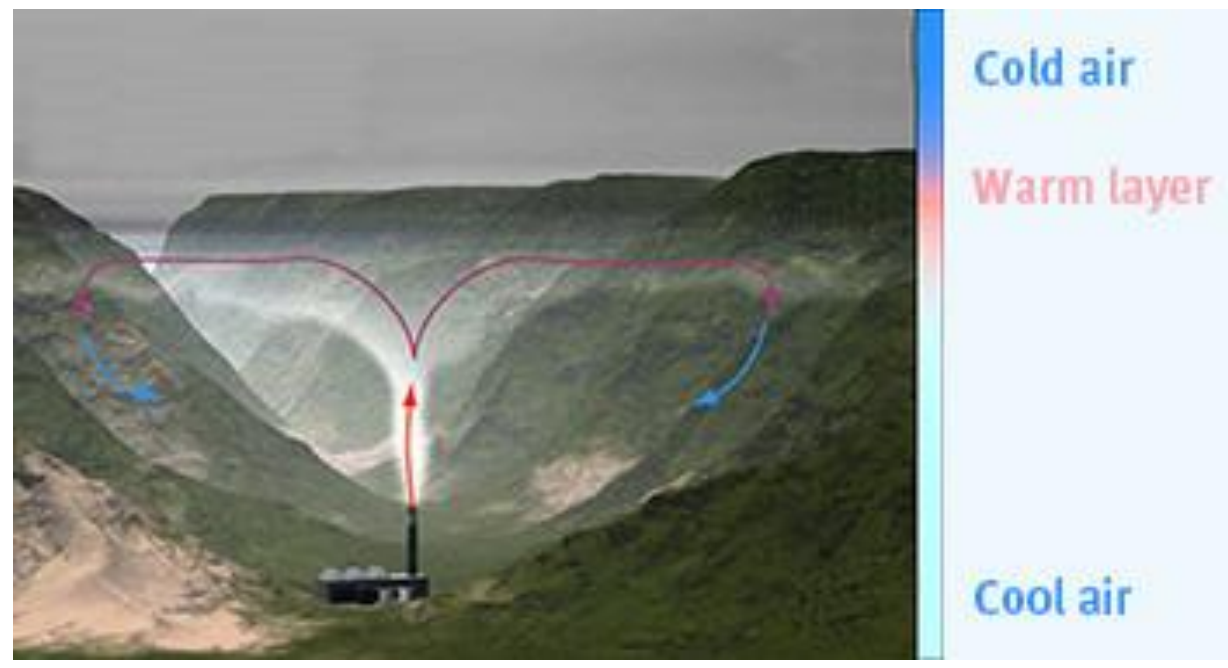

Figure 3: Temperature Inversion (Queensland, 2013)

\subsection{Natural Gas Transmission and Compressor Stations}

A natural gas compressor station is sometimes referred to as a transmission station. The difference between the two depends on the vernacular of the user. Technically, a transmission station is a compressor station, but it is usually characterized by the width of the lines running into the station. Transmission stations can be characterized as stations that utilize 20-48in lines, while compressor stations are anything smaller. A compressor station and transmission station both serve the same purpose and both house compressors.

Compressor stations are facilities that help move natural gas through transmission lines. Transmission lines are characterized as the highways by which natural gas is transferred across state lines. These compressor stations are located between 50-100 miles between one another (Naturalgas.org, 2013). These lines, in contrast to smaller local lines are usually 20-48inches in diameter. As natural gas moves through these lines, differences in distance, friction, and elevation slow the movement of the gas, and reduce pressure. 
These compressor stations are placed to maintain the pressure within the lines in order to alleviate the factors mentioned (Messersmith, 2019).

Once natural gas enters the compressor facility, gas is directed through scrubbers and filters to extract liquids and remove solids in the gas. Once this process has taken place, natural gas is directed through other piping to the compressor. Through the process of compressing the gas, heat is generated that must be dissipated.

Most compressor stations are fueled by a portion of the gas that flows through them. Either conventional engines or natural gas turbine units drive compressor stations. Depending on operational design, compressor stations can be located outside or housed in a building to facilitate maintenance and sound management (Messersmith, 2019).

\section{Chapter 3: Objectives of Study}

An analysis of UFPs near a natural gas transmission station needed to be conducted. This study was designed to compare UFP concentrations near a natural gas transmission station and number concentrations associated with background. The first objective of this study was to compare the two concentrations to determine natural gas transmission station UFP concentrations. The null hypothesis of the study was that there were no statistically significant difference between particle concentrations near the transmission station and the background. The second objective of this study was to evaluate weather conditions and whether or not wind speed, wind direction, and temperature were factors that affect particle concentrations near the transmission station.

\subsection{Sampling Environment:}


This transmission station was selected because of access. The transmission station was located directly beside the property of several individuals, which made it ideal because of distance. Several landowners were contacted that reside near the compressor station. Three of the respondents gave permission to conduct sampling on their property.

The transmission station in question houses a 16 -cylinder Cooper-Bessemner compressor. This compressor is solely powered off of natural gas. It is also worth noting that the compressor operates 24 hours a day, 365 days of the year.

\subsection{Equipment Used}

To complete this study, two pieces of equipment were required: A TSI P-Trak particle counter and an Oregon Scientific WMR 200. The TSI P-Trak was used to determine UFP number concentrations, while the Oregon Scientific WMR 300 determined wind speed, wind direction, and temperature.

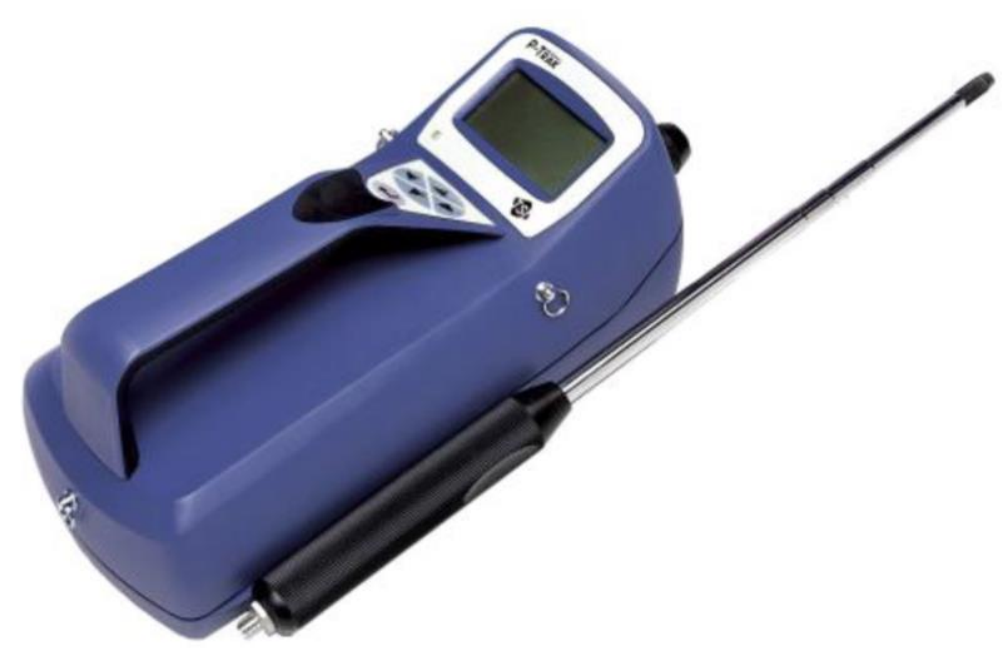

Figure 4: TSI P Trak Model 8525(TSI Incorporated, 2013) 


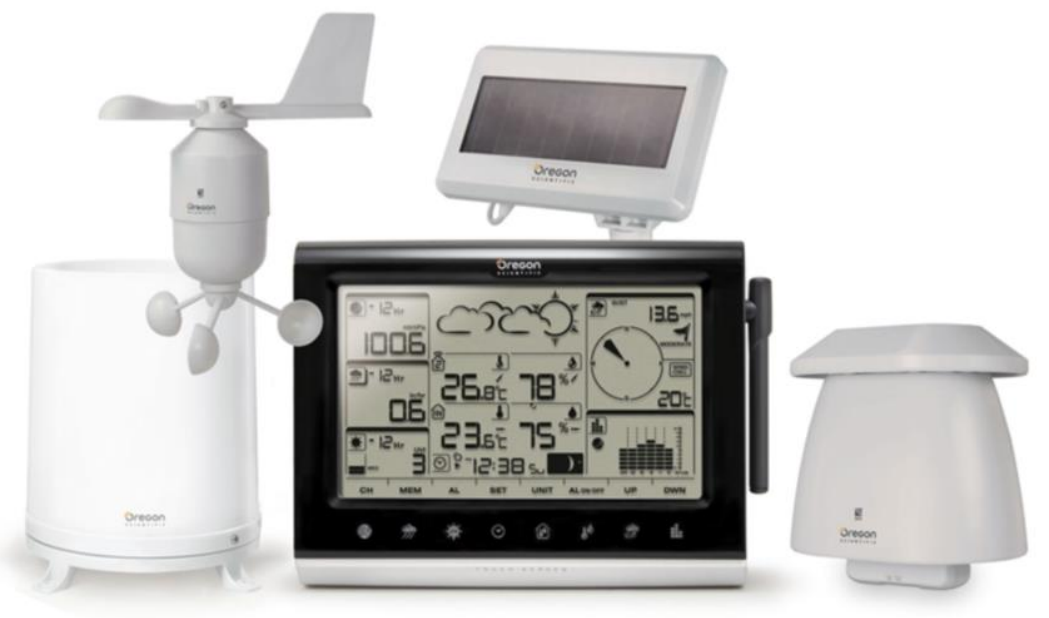

Figure 5: Oregon Scientific WMR 200 Weather Station (Oregon Scientific)

The process of collecting UFP number concentrations was completed by using a TSI P-Trak Ultrafine Particle Counter, Model 8525. The P-Trak is a direct reading instrument with the capability of measuring number concentrations from $0-5 \times 10^{\wedge} 5$ particles $/ \mathrm{cm}^{3}$ (TSI Incorporated. 2013).

The P-Trak operates by drawing particles through an internal pump. Upon entering the instrument, particles pass through a saturator tube where they mix with alcohol vapor. The particles then pass through a condenser tube where the alcohol condenses onto the particles causing them to grow into larger droplets. The droplets then pass through a focused laser beam, producing flashes of light that are sensed by a photo-detector. The number concentrations are determined by counting the light flashes. If the particles were not grown into larger droplets they wouldn't produce (scatter) enough light to be detected. A diagram detailing operation can be found below. (TSI Incorporated, 2012) 


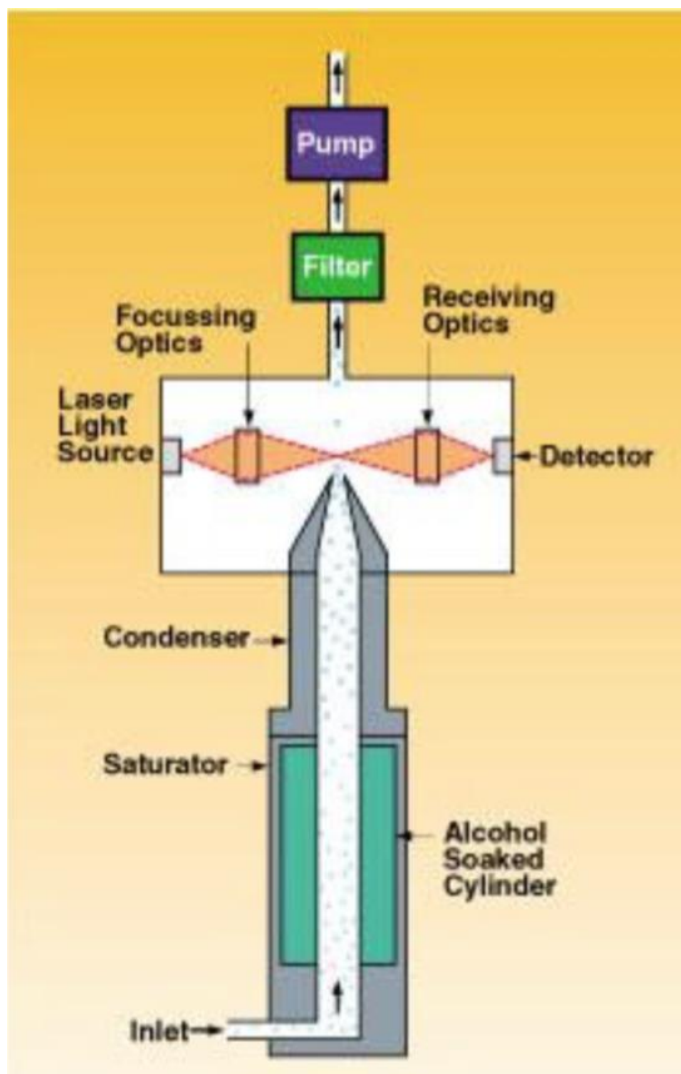

Figure 6: Working Diagram of P-Trak, (TSI, 2012)

\subsection{Experimental Setup}

Three sampling locations were established during this study. The locations are aptly named Sampling Locations One, Two, and Three. Along with the three locations, two sampling stations were identified. Station One remained at Location One throughout the sampling process. Station Two was located at sampling Location Two and Three. Station one was positioned directly to the west of the compressor station, approximately $2205 \mathrm{ft}$ away from the compressor station. This sampling station sat on the top of a ridge following the gas line right of way, approximately $463 \mathrm{ft}$ in elevation above the compressor. Sampling Location Two was established on a piece of opposing property, approximately 548ft from the compressor station. Sampling Location Three was positioned directly to the 
north of the station. This station sits horizontal to the compressor station at a distance of approximately $248 \mathrm{ft}$, and at approximately the same elevation.

Sampling Station One collected data throughout the sampling process. Sampling Station two collected data for 9 days at Location Two and 5 days at Location Three. The difference in sampling days between locations two and three is accounted for in the fact that after data was collected at sampling location Two. Permission was given to sample on another respondent's property, which was closer to the transmission station. Sampling Location One was selected as to be able to collect background UFP concentrations. This was completed by finding property upwind of the sampling location. As previously stated, the wind in this area primarily blows from the west. This, along with the elevation difference, assures us the ability to track background concentrations not associated with the compressor station.

Table 1 has been attached below to demonstrate the distance from each sampling station to the compressor station, and the elevation difference. Another picture is shown below to help the reader identify each sampling location.

\begin{tabular}{|c|c|c|c|}
\hline & $\begin{array}{c}\text { Sampling } \\
\text { Location 1 }\end{array}$ & $\begin{array}{c}\text { Sampling } \\
\text { Location 2 }\end{array}$ & $\begin{array}{c}\text { Sampling } \\
\text { Location 3 }\end{array}$ \\
\hline Distance to Compressor Location(ft.) & $\mathbf{2 2 0 5}$ & $\mathbf{5 4 8}$ & $\mathbf{4 6 3}$ \\
\hline $\begin{array}{c}\text { Elevation Difference: Sampling Location } \\
\text { vs. Compressor Station (ft.) }\end{array}$ & 463 & Negligible & Negligible \\
\hline
\end{tabular}

Table 1: Difference in Distance and Elevation between each Sampling Location 


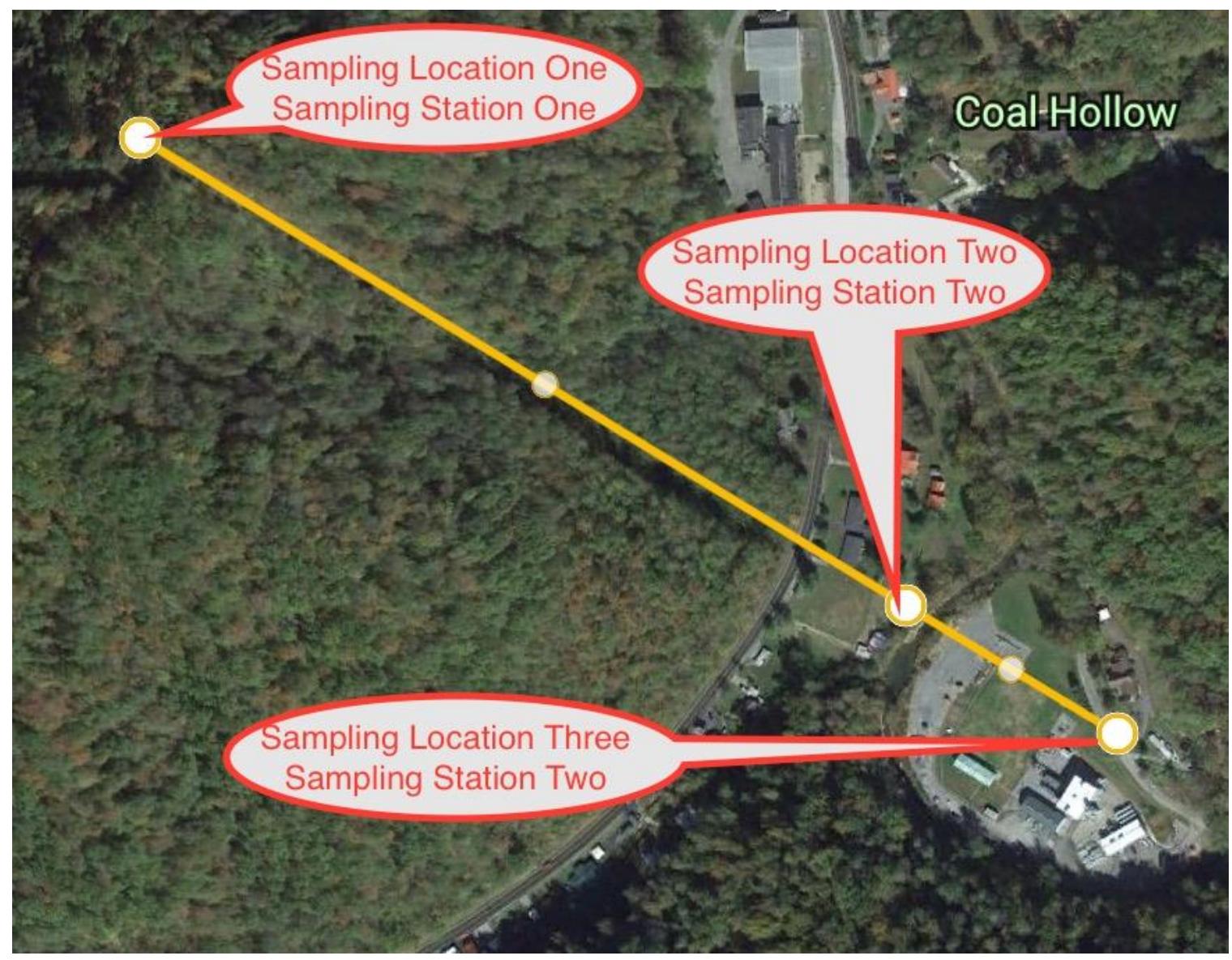

Figure 7: Sampling Locations and Sampling Stations

\subsubsection{Sampling Location One:}

The first sampling location was selected as to be able to collect background UFP number concentrations. This was completed by finding property upwind of the sampling location. As previously stated, the wind in this area primarily blows from the west. This, along with the elevation difference, assures us with the ability to track background concentrations not associated with the transmission station.

\subsubsection{Sampling Locations Two and Three:}


Sampling Locations Two and Three were primarily selected for their proximity to the compressor station. Sampling locations Two and Three are both in the valley at approximately the same elevation as the compressor station.

Along with the P-Trak at Station 2, an Oregon Scientific WMR 200 Weather Station was also used to track wind direction, wind speed, and temperature. The weather station accompanied the sampling station so that weather data could be collected simultaneously with the particle concentrations. The weather station was set to collect and record weather data every 10 minutes. This weather data would then be statistically analyzed later on in this study.

Two P-Tracks were set up at different locations to track particle concentrations. One P- Trak was set up at the top of a ridge directly to the west of the compressor station, Location One/Station One. This location was picked in order to be able to pick up background UFP concentrations from the surrounding areas. From looking at monthly meteorological data from previous years, it was clear that wind primarily blows from the West. Due to the nature of the study, this was important so background UFP concentrations could be recorded from up wind of the compressor station.

\subsection{Sampling Procedure}

\section{Protocol:}

Before field sampling could occur, a protocol was developed in order to collect data in a uniform manner.

\section{P-Trak was activated}

2. P-Trak automatically went through startup procedures (60 seconds). 


\section{P-Trak as then allowed to run for $\mathbf{5}$ minutes.}

4. Storage cap was be removed and alcohol cartridge would be inserted.

5. A zero calibration filter was attached to inlet screen assembly and allowed to run for 30 seconds.

6. P-Trak obtained zero calibration.

7. Zero filter detached.

8. Six inch length of Tygon tubing was attached.

9. P-Trak was set to record data every second.

10. P-Trak was then placed into log mode.

11. P-Trak began sampling and data logging.

Sampling Station One was be accessed at approximately 7:35 A.M. each morning. The P- Trak was turned on, zeroed, and set to record data each second. It then took approximately 15 minutes to return to Locations Two and Three. The P-Trak was then be turned on at those stations and set to record each second. Around four hours into each sampling day, the alcohol cartridge that holds the TSI isopropyl alcohol had to be replaced. The battery life on the P-Trak was also checked. The sampling then resumed until the end of the sampling period.

At the end of the sampling period, the P-Traks were obtained and returned for data extraction. Once returned, data from each of the P-Traks was extracted via software compatible with the P-Traks. The sampling data was then exported to excel spreadsheets. Along with the sampling data, weather data was also recorded and exported to excel spreadsheets for analysis. 


\subsection{P-Trak Correction Factor:}

The two P-Traks were compared in order to factor the compatibility between the two monitors. A TSI Particle generator was obtained to assist with data analysis. Both PTraks were put through their zero calibration procedure, and then set to record single point measurements. The two P-Traks was placed side by side at $4 \mathrm{ft}$ intervals.

\begin{tabular}{|c|c|c|c|c|c|c|c|}
\hline \multicolumn{7}{|c|}{ Concentration Comparison Between P-Traks } \\
\hline \multicolumn{2}{|c|}{$4 \mathrm{ft}$} & \multicolumn{2}{c|}{$8 \mathrm{ft}$} & \multicolumn{2}{c|}{$12 \mathrm{ft}$} & \multicolumn{3}{c|}{$16 \mathrm{ft}$} \\
\hline SN:02031013 & $\mathrm{SN}: 1009003$ & SN:02031013 & SN:1009003 & SN:02031013 & SN:1009003 & SN:02031013 & SN:1009003 \\
\hline 2190 & 2550 & 2270 & 2470 & 1970 & 2180 & 1660 & 1870 \\
\hline 2420 & 2690 & 2180 & 2490 & 1930 & 2230 & 1620 & 1870 \\
\hline 5160 & 5780 & 2310 & 2580 & 1820 & 2120 & 1630 & 1880 \\
\hline 1640 & 1940 & 2090 & 2310 & 1840 & 2120 & 1600 & 1860 \\
\hline 1920 & 2120 & 1960 & 2230 & 1820 & 2080 & 1550 & 1800 \\
\hline Average (PT/CC) & \multicolumn{2}{|c|}{ Average (PT/CC) } & Average (PT/CC) & Average (PT/CC) \\
\hline 2666 & 3016 & 2162 & 2416 & 1876 & 2146 & 1612 & 1856 \\
\hline
\end{tabular}

Table 2: Number Concentration Comparison Between P-Traks

From the table above, we see some variation between two P-Traks. It was determined that P-Trak SN:02031013 had been calibrated most recently. Since this was the case, a correction factor was added to all data points taken by SN:1009003. In order to maintain equality between samples in the study, P-Trak SN: 1009003 was always placed at Station One, while P-Trak SN: 0203113 was placed at Station Two.

\section{Chapter 4: Results}

\subsection{Measurements}

Fourteen days of sampling was conducted to compare number concentrations from background and concentrations near the compressor station. A comprehensive table of 
every day's sampling can be found in Appendix C. Each day's worth of sampling was

analyzed separately per location, accounting for a total of 28 samples. Table 3 shows a

summary of each day's sampling. This chart is useful in comparing average and maximum

concentration in each of the sampling days.

\begin{tabular}{|c|c|c|c|c|c|c|c|}
\hline \multirow[b]{2}{*}{ Day } & \multicolumn{6}{|c|}{ Number Concentrations Between Station 1 and Station 2 (PT/CC) } & \multirow[b]{2}{*}{ Maximum } \\
\hline & Station & Geometric Mean & Geometric SD & Arithmetic Mean & Arithmetic SD & Minimum & \\
\hline \multirow{3}{*}{ 20-Sep } & Station 1 & 1117 & 3522 & 1643 & 1290 & 0 & 7489 \\
\hline & Station 2 & 2806 & 7557 & 4255 & 3529 & 533 & 19228 \\
\hline & Station 1 & 543 & 2554 & 986 & 906 & 0 & 4956 \\
\hline \multirow[t]{2}{*}{ 21-Sep } & Station 2 & 4046 & 6864 & 4699 & 2944 & 1249 & 23591 \\
\hline & Station 1 & 1492 & 2790 & 1993 & 2404 & 764 & 23245 \\
\hline \multirow[t]{2}{*}{ 29-Sep } & Station 2 & 1134 & 1427 & 1189 & 901 & 740 & 19527 \\
\hline & Station 1 & 676 & 1989 & 1216 & 1500 & 0 & 8445 \\
\hline \multirow[t]{2}{*}{ 30-Sep } & Station 2 & 2559 & 4274 & 2988 & 2047 & 1331 & 16769 \\
\hline & Station 1 & 1666 & 3114 & 2059 & 1531 & 706 & 8413 \\
\hline \multirow[t]{2}{*}{$1-O c t$} & Station 2 & 3482 & 7452 & 4866 & 4850 & 1328 & 30063 \\
\hline & Station 1 & 3869 & 5920 & 4231 & 1839 & 1682 & 11710 \\
\hline \multirow[t]{2}{*}{ 2-Oct } & Station 2 & 5076 & 8770 & 5894 & 3467 & 1339 & 32633 \\
\hline & Station 1 & 2437 & 4630 & 3061 & 2335 & 955 & 13115 \\
\hline \multirow[t]{2}{*}{ 3-Oct } & Station 2 & 3260 & 6181 & 4178 & 4255 & 1333 & 37523 \\
\hline & Station 1 & 3012 & 6133 & 4020 & 3604 & 1356 & 22689 \\
\hline \multirow[t]{2}{*}{ 4-Oct } & Station 2 & 3197 & 7092 & 4528 & 4332 & 730 & 28729 \\
\hline & Station 1 & 1735 & 2312 & 1816 & 621 & 1147 & 4306 \\
\hline \multirow[t]{2}{*}{ 5-Oct } & Station 2 & 2645 & 4498 & 3207 & 3639 & 1382 & 48205 \\
\hline & Station 1 & 5305 & 11319 & 6726 & 4125 & 1414 & 29774 \\
\hline \multirow[t]{2}{*}{ 3-Dec } & Station 2 & 5728 & 10585 & 7193 & 6008 & 3189 & 38773 \\
\hline & Station 1 & 1588 & 2990 & 2069 & 2425 & 586 & 26167 \\
\hline \multirow[t]{2}{*}{ 4-Dec } & Station 2 & 1669 & 3410 & 2829 & 6972 & 803 & 68030 \\
\hline & Station 1 & 984 & 2287 & 1229 & 1981 & 1 & 28609 \\
\hline \multirow[t]{2}{*}{ 5-Dec } & Station 2 & 3328 & 7354 & 5106 & 7464 & 1263 & 72407 \\
\hline & Station 1 & 3898 & 7652 & 5328 & 6446 & 1650 & 47126 \\
\hline \multirow[t]{2}{*}{ 6-Dec } & Station 2 & 5615 & 16290 & 9337 & 13116 & 0 & 112438 \\
\hline & Station 1 & 3497 & 8221 & 4625 & 3894 & 0 & 38680 \\
\hline 7-Dec & Station 2 & 4435 & 8229 & 5448 & 4316 & 1530 & 42062 \\
\hline
\end{tabular}

Table 3: Number Concentrations Between Station One and Two 
Although this chart is useful for a general overview of each day's sampling, it does not tell the full story or develop a comprehensive picture. It is worth noting that this chart illustrates the maximum number concentration for each location in the sampling period. Interestingly enough, only one day showed a higher maximum number concentration for the background station at Location One.

Along with the number concentration measurements, a weather station ran simultaneously collecting wind speed, wind direction, and temperature data every ten minutes. This data would later be used in a regression analysis comparing particle count concentrations to the listed weather conditions. Table 4 shows a summary of each day's weather conditions. It is interesting to note that each day's worth of sampling showed the wind blowing from a south and southeastern direction.

\begin{tabular}{|c|c|c|c|}
\hline \multicolumn{4}{|c|}{ Weather Data } \\
\hline Day & Average Wind Direction $\mathbf{( 3 6 0}^{\circ}$ ) & Average Wind Speed (mph) & Average Temperature ( $\left.{ }^{\circ} \mathbf{F}\right)$ \\
\hline 20-Sep & 130.2 & 0.0 & 78.7 \\
\hline 21-Sep & 105.5 & 0.8 & 78.8 \\
\hline 29-Sep & 155.1 & 1.1 & 71.6 \\
\hline 30-Sep & 146.5 & 0.7 & 70.7 \\
\hline 1-Oct & 128.8 & 0.2 & 72.0 \\
\hline 2-Oct & 97.6 & 0.0 & 69.3 \\
\hline 3-Oct & 100.8 & 0.2 & 75.8 \\
\hline 4-Oct & 141.1 & 1.1 & 74.4 \\
\hline 5-Oct & 71.0 & 0.0 & 71.3 \\
\hline 3-Dec & 167.0 & 2.4 & 46.3 \\
\hline 4-Dec & 107.5 & 0.7 & 37.6 \\
\hline 5-Dec & 157.2 & 1.0 & 33.5 \\
\hline 6-Dec & 143.6 & 1.3 & 37.1 \\
\hline 7-Dec & 184.9 & 1.6 & 39.1 \\
\hline
\end{tabular}

Table 4: Summary of Weather Data 


\subsection{Comparison Between Stations:}

A comparison between the two stations was needed to understand if there was an agreeableness with the null hypothesis. To help quantify the relationship between Stations One and Two, a Paired T-Test was conducted. This statistical analysis provided on opportunity to see if there is any statistically significant difference between the two sets of data from each day. The null hypothesis states that there is no statistically significant difference between the two samples. With $\alpha=0.05$, the P-value for each day would be evaluated. If the analysis rendered $\mathrm{P}<\alpha$, then we would reject the null hypothesis.

\begin{tabular}{|c|c|}
\hline \multicolumn{2}{|c|}{ Paired T Test } \\
\hline Day & P-Value \\
\hline 20-Sep & $1.32463 \mathrm{E}-56$ \\
\hline 21-Sep & $1.22701 \mathrm{E}-86$ \\
\hline 29-Sep & $2.77459 \mathrm{E}-11$ \\
\hline 30-Sep & $8.25198 \mathrm{E}-60$ \\
\hline 1-Oct & $4.17385 \mathrm{E}-37$ \\
\hline 2-Oct & $2.11526 \mathrm{E}-26$ \\
\hline 3-Oct & $1.41511 \mathrm{E}-14$ \\
\hline 4-Oct & 0.0009038 \\
\hline 5-Oct & $2.71602 \mathrm{E}-08$ \\
\hline 3-Dec & 0.156781914 \\
\hline 4-Dec & 0.074828264 \\
\hline 5-Dec & $1.41036 \mathrm{E}-11$ \\
\hline 6-Dec & $1.37854 \mathrm{E}-06$ \\
\hline 7-Dec & 0.000613743 \\
\hline
\end{tabular}

Table 5: Paired T-Test

Every case, except for the samples taken on December 3-4 showed that we would reject the null hypothesis. The graphs in Appendix A show the relationship between the two stations, and the difference between the two data sets. From each one of these graphs, 
we can see a trend in the chart patterns. This trend seems to show that particle concentrations are higher in the morning, and trend down toward the middle of the day, or noon.

\subsection{Comparing Weather Conditions to Station 2 Concentrations:}

To compare weather conditions to Station Two's number concentrations, number concentrations needed to be averaged to every $10^{\text {th }}$ minute. This process would allow for us to wholly match and analyze weather conditions to number concentrations.

Due to the large nature of the study, it was clear that a regression analysis should be conducted. With so many data sets, statistical quantification was used to focus on the interpretation of results. To compare weather conditions to number concentrations, a regression analysis was used by pairing wind direction, wind speed, and temperature to each day's number concentrations. Table 6 summarizes the regression analysis results, including the P-value for each set. Three sets of temperature data are notated "-"due to the fact the wind speed was $0 \mathrm{mph}$. 


\begin{tabular}{|c|c|c|c|c|c|}
\hline \multicolumn{3}{|c|}{ Regression Analysis } & \multicolumn{3}{|c|}{ Regression Analysis } \\
\hline Day & Variables & P-Value & Day & Variables & P-Value \\
\hline \multirow{3}{*}{ 20-Sep } & Temperature & $7.48 \mathrm{E}-08$ & \multirow{3}{*}{ 4-Oct } & Temperature & $3.29 E-07$ \\
\hline & Wind Direction & 0.725084207 & & Wind Direction & 0.010660505 \\
\hline & Wind Speed & - & & Wind Speed & 0.278371216 \\
\hline \multirow{3}{*}{ 21-Sep } & Temperature & 0.08959542 & \multirow{3}{*}{ 5-Oct } & Temperature & 0.867733239 \\
\hline & Wind Direction & 0.615476327 & & Wind Direction & 0.219621573 \\
\hline & Wind Speed & 0.499698164 & & Wind Speed & - \\
\hline \multirow{3}{*}{ 29-Sep } & Temperature & 0.389115708 & \multirow{3}{*}{ 3-Dec } & Temperature & 0.046845517 \\
\hline & Wind Direction & 0.31796358 & & Wind Direction & 0.099048959 \\
\hline & Wind Speed & 0.21584659 & & Wind Speed & 0.020048157 \\
\hline \multirow{3}{*}{ 30-Sep } & Temperature & 0.027980764 & \multirow{3}{*}{ 4-Dec } & Temperature & 0.444629194 \\
\hline & Wind Direction & 0.1390988 & & Wind Direction & 0.815046525 \\
\hline & Wind Speed & 0.2239546 & & Wind Speed & 0.595235474 \\
\hline \multirow{3}{*}{ 1-Oct } & Temperature & 0.242600654 & \multirow{3}{*}{ 5-Dec } & Temperature & 0.639003663 \\
\hline & Wind Direction & 0.421879709 & & Wind Direction & 0.46309166 \\
\hline & Wind Speed & 0.382462204 & & Wind Speed & 0.302014333 \\
\hline \multirow{3}{*}{ 2-Oct } & Temperature & $1.15 \mathrm{E}-08$ & \multirow{3}{*}{ 6-Dec } & Temperature & 0.008184044 \\
\hline & Wind Direction & 0.799738713 & & Wind Direction & 0.978960824 \\
\hline & Wind Speed & - & & Wind Speed & 0.902791966 \\
\hline \multirow{3}{*}{ 3-Oct } & Temperature & $1.30 \mathrm{E}-05$ & \multirow{3}{*}{ 7-Dec } & Temperature & $8.14 \mathrm{E}-05$ \\
\hline & Wind Direction & 0.669074774 & & Wind Direction & 0.240129291 \\
\hline & Wind Speed & 0.894982374 & & Wind Speed & 0.931088858 \\
\hline
\end{tabular}

Table 6: Regression Analysis

Due to the large nature of this study an ANOVA analysis was conducted in order to be able to interpret how weather data correlated to Station Two. This process allowed for the comparison of particle counts along with weather condition. As in the Paired T-Test, the ANOVA used $\alpha=0.05$. If the P-values were smaller than $\alpha$, we would reject the null hypothesis. If the null hypothesis is rejected it can be said that the difference between the two data sets is statistically significant. Table 7 summarizes the ANOVA results, including the P-value for each set. The null hypothesis was rejected 7 out of 14 sets. 


\begin{tabular}{|c|c|}
\hline \multicolumn{2}{|c|}{ ANOVA } \\
\hline Day & P-Value \\
\hline 20-Sep & $2.6081 \mathrm{E}-09$ \\
\hline 21-Sep & 0.205949061 \\
\hline 29-Sep & 0.226792015 \\
\hline 30-Sep & 0.099523932 \\
\hline 1-Oct & 0.000701065 \\
\hline 2-Oct & $1.39324 \mathrm{E}-07$ \\
\hline 3-Oct & $6.01156 \mathrm{E}-05$ \\
\hline 4-Oct & $4.25739 \mathrm{E}-10$ \\
\hline 5-Oct & 0.228432993 \\
\hline 3-Dec & 0.052886029 \\
\hline 4-Dec & 0.866368502 \\
\hline 5-Dec & 0.678891414 \\
\hline 6-Dec & 0.01641586 \\
\hline 7-Dec & 0.000184333 \\
\hline
\end{tabular}

Table 7: ANOVA

\subsection{Atmospheric Stability Classification}

Since 10 of 14 samples in our regression analysis showed a correlation in temperature and number concentration, further investigation needed to occur. Atmospheric stability is defined as the tendency for a parcel of air to move upward or downward after it has been displaced vertically by a small amount (McQuaid, 1981). This classification scheme allows one to classify the atmosphere in terms of stability, stable and unstable. Unstable atmospheres tend to develop vertical updrafts, while stable atmospheres tend to suppress these updrafts.

Several charts are available so that one can classify atmospheric stability. The one that was decided upon for this study accounts for low and stable wind conditions. When 
wind conditions are such as we observed in this study, one may use this classification scheme to classify atmospheric stability.

In order to determine this classification two sets of data were needed. Firstly, a change in temperature between two locations had to be calculated, noted as $\Delta \mathrm{T}$. The temperature located in the valley would be subtracted from the local temperature, which can be associated to the temperature at the top of a mountain. The sum of the temperature difference would then be converted into $\mathrm{K}^{\circ}$ for applicability to the Pasquill Stability Class. After temperature was accounted for, a difference in elevation (m) would then need to be calculated. Table 8 details the stability classes and the equation, which was used to evaluate each data set.

\begin{tabular}{|c|c|}
\hline Pasquill Stability Class & $\boldsymbol{\Delta T} / \Delta \mathrm{z}$ (degrees $\mathrm{K} / \mathbf{1 0 0 m}$ ) \\
\hline A & $\Delta \mathrm{T} / \Delta \mathrm{z}<-1.9$ \\
\hline $\mathrm{B}$ & $-1.9 \leq \Delta \mathrm{T} / \Delta \mathrm{z}<-1.7$ \\
\hline $\mathrm{C}$ & $-1.7 \leq \Delta \mathrm{T} / \Delta \mathrm{z}<-1.5$ \\
\hline $\mathrm{D}$ & $-1.5 \leq \Delta \mathrm{T} / \Delta \mathrm{z}<-0.5$ \\
\hline $\mathrm{E}$ & $-0.5 \leq \Delta \mathrm{T} / \Delta \mathrm{z}<1.5$ \\
\hline $\mathrm{F}$ & $1.5 \leq \Delta \mathrm{T} / \Delta \mathrm{z}<4.0$ \\
\hline $\mathrm{G}$ & $4.0 \leq \Delta \mathrm{T} / \Delta \mathrm{z}$ \\
\hline
\end{tabular}

Table 8: Atmospheric Stability Classification

Each day's worth of temperature data was then compiled into tables, an example of this can be found below labeled Figure 16. Each day's worth of data can also be found in Appendix B of this study. From this table we tend to see that all of our Atmospheric stability classifications fall in the E and F Pasquill Stability Class. From this classification, it can be determined that we tended to see a stable atmosphere in which little to no updraft is present. 
As stated previously, when inversions occur under stable atmospheric conditions, we see emissions staying close to the surface of the earth. From the atmospheric stability classification, we can see that the atmosphere was stable on each day of sampling. Furthermore, if we look at the $\Delta \mathrm{T}\left(\mathrm{F}^{\circ}\right)$ for each day's sampling, we should be able to see when an inversion has occurred. In the table below, we see that the valley was warmer until 0950. Around this time we see an inversion. For the purposes of this study, any $\Delta \mathrm{T}\left(\mathrm{F}^{\circ}\right)$ of greater than one degree will be classified as an inversion. From 0950 to 1150 we see this inversion occur. Around 1210 we see the temperature gradient return to normal allowing for emissions to rise until they reach equilibrium. 


\begin{tabular}{|c|c|c|c|c|c|}
\hline \multicolumn{6}{|c|}{ Atmospheric Stability (September 20) } \\
\hline Time & Valley $\left(\mathrm{F}^{\circ}\right)$ & Mountain $\left(\mathrm{F}^{\circ}\right)$ & $\Delta \mathbf{T}\left(\mathbf{F}^{\circ}\right)$ & $\Delta \mathrm{T}\left(\mathrm{K}^{\circ}\right)$ & $\mathrm{K}^{\circ} /$ Elevation $(\mathrm{m})$ \\
\hline 7:50 & 67 & 65 & -2 & 254.04 & 1.18 \\
\hline $8: 10$ & 68 & 65 & -3 & 292.93 & 1.36 \\
\hline $8: 30$ & 68 & 65 & -3 & 292.93 & 1.36 \\
\hline $8: 50$ & 68 & 66 & -2 & 293.09 & 1.36 \\
\hline 9:15 & 69 & 67 & -2 & 293.46 & 1.36 \\
\hline 9:30 & 70 & 68 & -2 & 294.15 & 1.37 \\
\hline 9:50 & 71 & 71 & 0 & 294.65 & 1.37 \\
\hline $10: 10$ & 72 & 73 & 1 & 295.40 & 1.37 \\
\hline $10: 30$ & 73 & 75 & 2 & 296.15 & 1.38 \\
\hline $10: 50$ & 76 & 76 & 0 & 297.76 & 1.38 \\
\hline $11: 10$ & 79 & 79 & 0 & 299.01 & 1.39 \\
\hline $11: 30$ & 81 & 81 & 1 & 300.09 & 1.40 \\
\hline $11: 50$ & 82 & 82 & 0 & 301.09 & 1.40 \\
\hline $12: 10$ & 84 & 82 & -2 & 301.96 & 1.40 \\
\hline $12: 30$ & 85 & 84 & -1 & 302.76 & 1.41 \\
\hline $12: 50$ & 86 & 85 & -1 & 303.29 & 1.41 \\
\hline $13: 10$ & 88 & 81 & -7 & 303.98 & 1.41 \\
\hline 13:35 & 88 & 83 & -5 & 304.51 & 1.42 \\
\hline $13: 50$ & 90 & 84 & -6 & 305.15 & 1.42 \\
\hline $14: 10$ & 89 & 85 & -4 & 305.04 & 1.42 \\
\hline $14: 30$ & 79 & 86 & 7 & 299.01 & 1.39 \\
\hline $14: 55$ & 90 & 84 & -6 & 305.32 & 1.42 \\
\hline $15: 10$ & 89 & 84 & -5 & 304.65 & 1.42 \\
\hline
\end{tabular}

Table 9: Atmospheric Stability for September 20th

\section{Chapter 5: Discussions and Conclusions}

The focus of this study was to compare number concentrations of UFPs near a compressor station to those of the background. Utilizing the P-Trak, each day's worth of sampling from Station One and Two were systematically evaluated to determine whether or not a relationship was present. When a Paired T-Test was used to evaluate the data, it was found the null hypothesis was rejected 12 of 14 days. The rejection of the null 
hypothesis meant that with respect to number concentration, there is a statistically significant difference between the two data sets.

\subsection{December 3-4}

There are a couple of reasons why the null hypothesis was rejected for sampling days December 3-4. When you look at the atmospheric stability charts for these two days, along with the $\Delta \mathrm{T}\left(\mathrm{F}^{\circ}\right)$ we see that the atmosphere is stable, but no inversions occurred. This could account for the number concentrations being so closely related when graphed. It is important to note here that maximum concentrations were still higher in the hollow near the transmission station for these days.

\subsection{Further Characterization}

Since the null hypothesis was rejected in 12 of 14 cases, indicating that there is a statistically significant difference between the two stations, other factors were looked upon to determine reasoning for the difference. Hence, wind direction, wind speed, and temperature were evaluated to determine if they showed any type of correlation with Locations Two and Three.

Wind speed was evaluated in a regression analysis and ANOVA for its statistical significance. In most cases, wind speed did not average $2 \mathrm{mph}$ for the day, excluding one day. When the regression analysis was completed, it was made clear that excluding Dec $3^{\text {rd }}$, wind speed did not show any correlation in the number concentrations that were ascribed.

Wind direction remained nearly constant throughout the sampling process. It was shown that wind at sampling Locations Two and Three primarily blew out of the southeast 
and sometimes from the south. This would lead us to make one of two assumptions: The first assumption being that the wind direction blew out of the hollow towards the weather station and subsequently, towards all sampling locations. The other assumption would be that we saw this due to a mixing effect in the valley. This can be fairly dismissed due to the fact that the Pasquill Stability Scheme showed that the atmosphere remained stable throughout sampling. When evaluated with a regression analysis, it was found in only one circumstance (October $3^{\text {rd }}$ ) to be statistically significant to the number concentrations recorded at Locations Two and Three.

Temperature then becomes our main point of interest. From the regression analysis we see that 8 of 14 data sets showed a correlation to in temperature and number concentrations. Of those days, we can also see from weather data that an inversion occurred in 6 of those 14 days. Three of these days both showed a statistical significance in temperature and an inversion had occurred. Table 10 was developed to track the statistical significance of temperature, number concentration with peaks between 8:30 AM-1100 AM, and inversions that were calculated from our $\Delta \mathrm{T}$ in degrees Fahrenheit. 


\begin{tabular}{|c|c|c|c|}
\hline \multicolumn{4}{|c|}{ Statistical Significance Vs. Number Concentration Peaks Vs. Inversion } \\
\hline Date & Statistical Significance & Peaks (08:30-11:00) & Inversion \\
\hline 20-Sep & $\mathrm{x}$ & $\mathrm{x}$ & $\mathrm{x}$ \\
\hline 21-Sep & $\mathrm{x}$ & $\mathrm{x}$ & $\mathrm{x}$ \\
\hline 29-Sep & & $\mathrm{x}$ & $\mathrm{x}$ \\
\hline 30-Sep & $\mathrm{x}$ & $\mathrm{x}$ & $\mathrm{x}$ \\
\hline 1-Oct & $\mathrm{x}$ & & $\mathrm{x}$ \\
\hline 2-Oct & $\mathrm{x}$ & $\mathrm{x}$ & \\
\hline 3-Oct & & $\mathrm{x}$ & $\mathrm{x}$ \\
\hline 4-Oct & $\mathrm{x}$ & $\mathrm{x}$ & \\
\hline 5-Oct & & $\mathrm{x}$ & \\
\hline 3-Dec & $\mathrm{x}$ & $\mathrm{x}$ & \\
\hline 4-Dec & $\mathrm{x}$ & $\mathrm{x}$ & \\
\hline 5-Dec & $\mathrm{x}$ & $\mathrm{x}$ & \\
\hline 6-Dec & $\mathrm{x}$ & $\mathrm{x}$ & \\
\hline 7-Dec & $\mathrm{x}$ & $\mathrm{x}$ & \\
\hline
\end{tabular}

Table 10: Statistical Significance of Weather Conditions vs. Number Concentrations vs. Inversions

\subsection{Peaks}

As one can see, number concentration peaks were the most prevalent of the three factors in the table above. Peaks were seen between 0830 and 1100 almost each day. When compared to background concentrations, these peaks were far above the background. This would lead us to believe that the transmission station was the source of these mourning peaks.

\subsection{Morning Traffic}

In this study, we primarily focused on comparing number concentrations to weather condition. Traffic throughout the morning was also observed. Three days of traffic rates between the hours of 0500-1000 were averaged between the days of February $4^{\text {th }}$ and $7^{\text {th }}$. 
Diesel vehicles were characterized as larger vehicles (tractor trailers, school buses, and coal trucks). All other vehicles were then characterized as gasoline vehicles. Table 11 below details this.

\begin{tabular}{|c|c|c|c|c|c|}
\hline \multicolumn{6}{|c|}{ Average Morning Traffic Rates } \\
\hline \multicolumn{5}{|c|}{ Time } & \multirow{2}{*}{ Type of Vehicle } \\
\hline $0500-0600$ & 0600-0700 & 0700-0800 & 0800-0900 & 0900-1000 & \\
\hline 4 & 9 & 6 & 5 & 4 & Diesel \\
\hline 52 & 102 & 82 & 74 & 71 & Gasoline \\
\hline
\end{tabular}

From Table 11 one can see that traffic rates are higher between the hours of 06000700. We can attribute this to individuals driving to work. It is important to note here that the peaks that were observed usually occurred between the hours of 0830 and 1100 hours. Locations Two and Three are both up wind of the highway, with the wind blowing south and south. As a result, traffic rates were not thought to be a contributing factor to the morning number concentration peaks.

\subsection{Conclusions}

This study tested the correlation between number concentrations recorded near a natural gas compressor station and the background. The findings of this study were based on 14 days of paired sampling between a background location and a location near a natural gas transmission station. The first objective of this study was to compare number concentrations near the compressor station to background number concentrations. It was found that averages and number concentrations near the transmission station were higher than the background. 
The second objective of this study was to evaluate weather conditions and whether or not wind speed, wind direction, and temperature were factors that affect number concentrations. It was found that out of these factors temperature was most highly correlated with particle concentrations near the compressor station.

Since these locations differed at a statistically significant level, it is recommended that more studies be completed to evaluate UFP number concentrations near natural gas compressor and transmission stations compared to background number concentrations.

\subsection{Limitations and Future Research}

This study was carried out as close to a natural gas transmission station as possible. Future studies should look into the possibility of partnering with a natural gas transmission company with a goal of achieving as close a proximity to the transmission station as possible.

This study was conducted at one natural gas transmission station that is the first of its kind. Future studies should focus on number concentrations at different facilities so that a clearer picture can be painted of the association between natural gas compressor stations and number concentrations. Future research may also want to focus on longer period studies so that atmospheric conditions and changes in the seasons can be more adequately accounted for. 


\section{References}

Britannica, T. E. (2016, March 28). Temperature Inversion. Retrieved February 6, 2019, from https://www.britannica.com/science/temperature-inversion

Chen, R., Hu, B., Liu, Y., Xu, J., Yang, G., Xu, D., \& Chen, C. (2016, March 16). Beyond PM2.5: The role of ultrafine particles on adverse health effects of air pollution. Retrieved February 5, 2019, from https://www.sciencedirect.com/science/article/pii/S0304416516300745

Clifford, S., Mazaheri, M., Salimi, F., Ezz, W. N., Yeganeh, B., Low-Choy, S., ... Morawska, L. (2018, May). Effects of exposure to ambient ultrafine particles on respiratory health and systemic inflammation in children. Retrieved January 7, 2019, from https://www.ncbi.nlm.nih.gov/pubmed/29514111

Donaldson, K., Stone, V., Renwick, \& MacNee. (2001, March 01). Ultrafine particles. Retrieved January 7, 2019, from https://oem.bmj.com/content/58/3/211

McQuaid. (1981). Appendix A: Atmospheric Stability Classification Schemes. Retrieved February 6, 2019, from http://ftp.feq.ufu.br/Luis_Claudio/Segurança/Safety/Estimating_the_Flammable_m ass_of_a_vapor_cloud/07781_app.pdf

Messersmith, D. (2019, January 23). Understanding Natural Gas Compressor Stations. Retrieved February 6, 2019, from https://extension.psu.edu/understandingnatural-gas-compressor-stations

Morawska, L., Ristovski, Z., Jayaratne, E. R., Keogh, D. U., \& Ling, X. (2008, August 07). Ambient nano and ultrafine particles from motor vehicle emissions: Characteristics, ambient processing and implications on human exposure. Retrieved February 6, 
2019, from

https://www.sciencedirect.com/science/article/pii/S1352231008006961

Naturalgas.org. (2013, September 20). NaturalGas.org. Retrieved February 6, 2019, from http://naturalgas.org/naturalgas/transport/

Oregon Scientific. (n.d.). Professional Weather Center Model: WMR 200/ WMR 200A

Weather Manual. Retrieved January 7, 2019, from

https://www.oregonscientificstore.com/manual/WMR200.pdf

Pirjola, I., Paasonen, P., Pfeiffer, D., D, H., Hammers, T., Koskentola, T., ... Ronkko, T. (2006).

WVU Libraries EZ-Proxy. Retrieved February 6, 2019, from https://wwwsciencedirect-

com.www.libproxy.wvu.edu/science/article/pii/S1352231005009805

Posner, L., \& Pandis, S. (2015, March 19). Sources of ultrafine particles in the Eastern United States. Retrieved January 7, 2019, from https://www.sciencedirect.com/science/article/pii/S1352231015002575

Queensland;, A. T. (2013, August 29). Inversions | Influence of meteorology on air quality. Retrieved February 6, 2019, from https://www.qld.gov.au/environment/pollution/monitoring/air/airmonitoring/meteorology-influence/meteorology-inversions

Rinaldo, Mickael, Andujar, Pascal, Martinon, Raffin, ... Patrick. (2015, March 20).

Perspectives in Biological Monitoring of Inhaled Nanosized Particles. Retrieved February 5, 2019, from https://academic.oup.com/annweh/article/59/6/669/2196085

Semmler, M., Seitz, J., Erbe, F., Mayer, P., Heyder, J., Oberdorster, G., \& Kreyling, W. (2004). 
Long-Term Clearance Kinetics of Inhaled Ultrafine Insoluble Iridium Particles from the Rat Lung, Including Transient Translocation into Secondary Organs. Retrieved February 5, 2019, from https://www.tandfonline.com/doi/abs/10.1080/08958370490439650

Solomon, P. A. (n.d.). Ultrafine Particles in Ambient Air. Retrieved January 16, 2019.

Thorley, A. J., Ruenraroengsak, P., Potter, T. E., \& Tetley, T. D. (2014). Critical Determinants of Uptake and Translocation of ... Retrieved February 5, 2019, from https://www.ncbi.nlm.nih.gov/pmc/articles/PMC4246006/

TSI. (2012). P-Trak Ultrafine Particle Counter Theory of Operation. Retrieved January 7, 2019, from https://www.tsi.com/getmedia/86507a08-210f-4708-9991b3c6cca9c2c1/ITI-071-App-Note-A4?ext=.pdf

TSI Incorporated. (2013). P-Trak Ultrafine Particle Counter Model 8525 Operation and Service Manual. Retrieved January 7, 2019, from https://www.tsi.com/getmedia/d1f26f38-5f1d-4851-80a2-b99d95c7c9c8/Model8525-P-Trak-Op_Svc_Mnl_1980380?ext=.pdf Virtanen, A., Ronkko, T., Kannosto, J., Ristimaki, J., Makela, J., Pakkanen, T., . . Pirjola, L. (2006). Winter and summer time size distributions and densities of ... Retrieved February 6, 2019, from https://core.ac.uk/download/pdf/52757784.pdf Zhang, K. M., \& Wexler, A. S. (2015, June 19). Modeling the number distributions of urban and regional aerosols: Theoretical foundations. Retrieved February 6, 2019, from https://ucdavis.pure.elsevier.com/en/publications/modeling-the-number-distributionsof-urban-and-regional-aerosols 


\section{Appendix A: Number Concentration Plots}

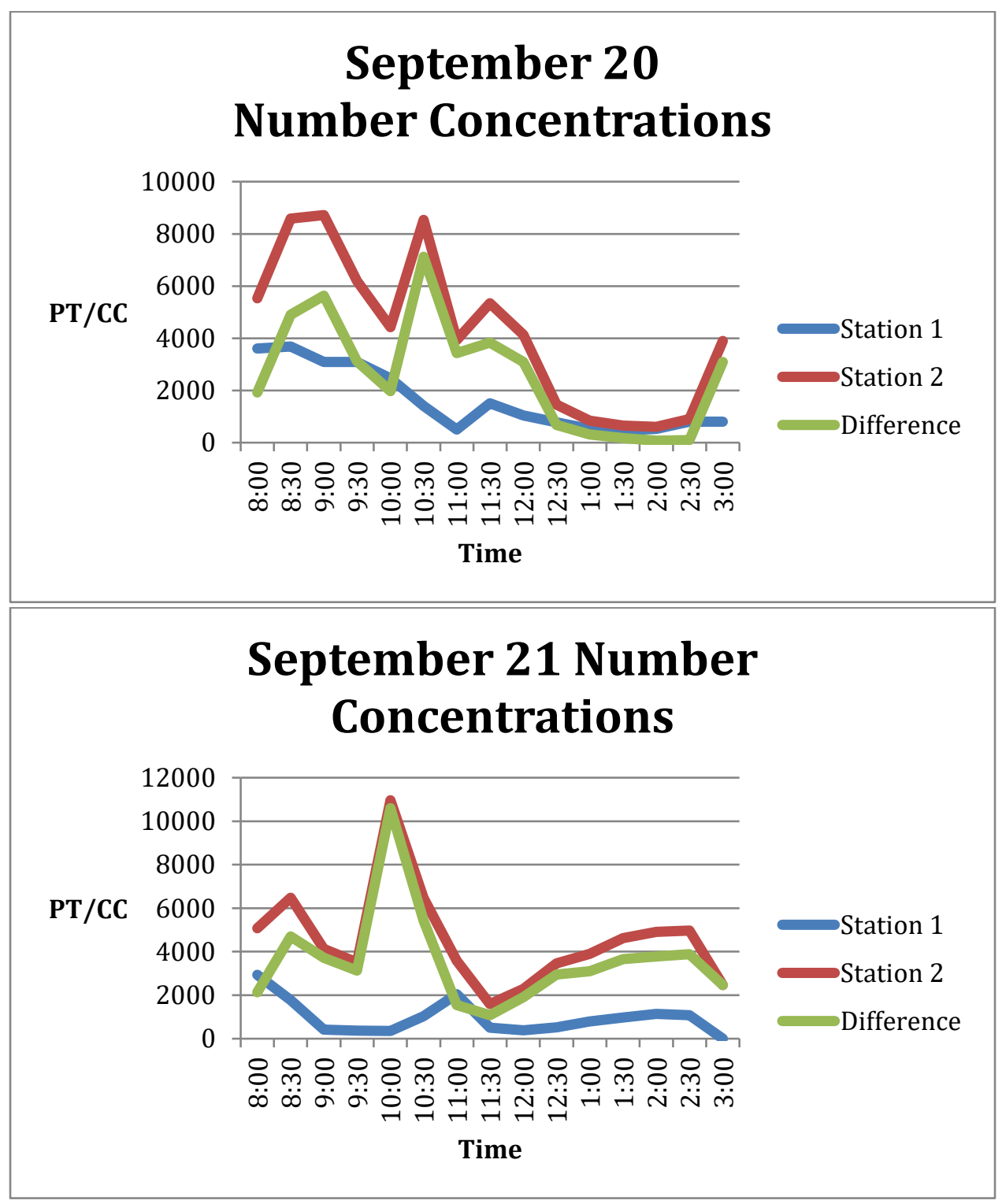




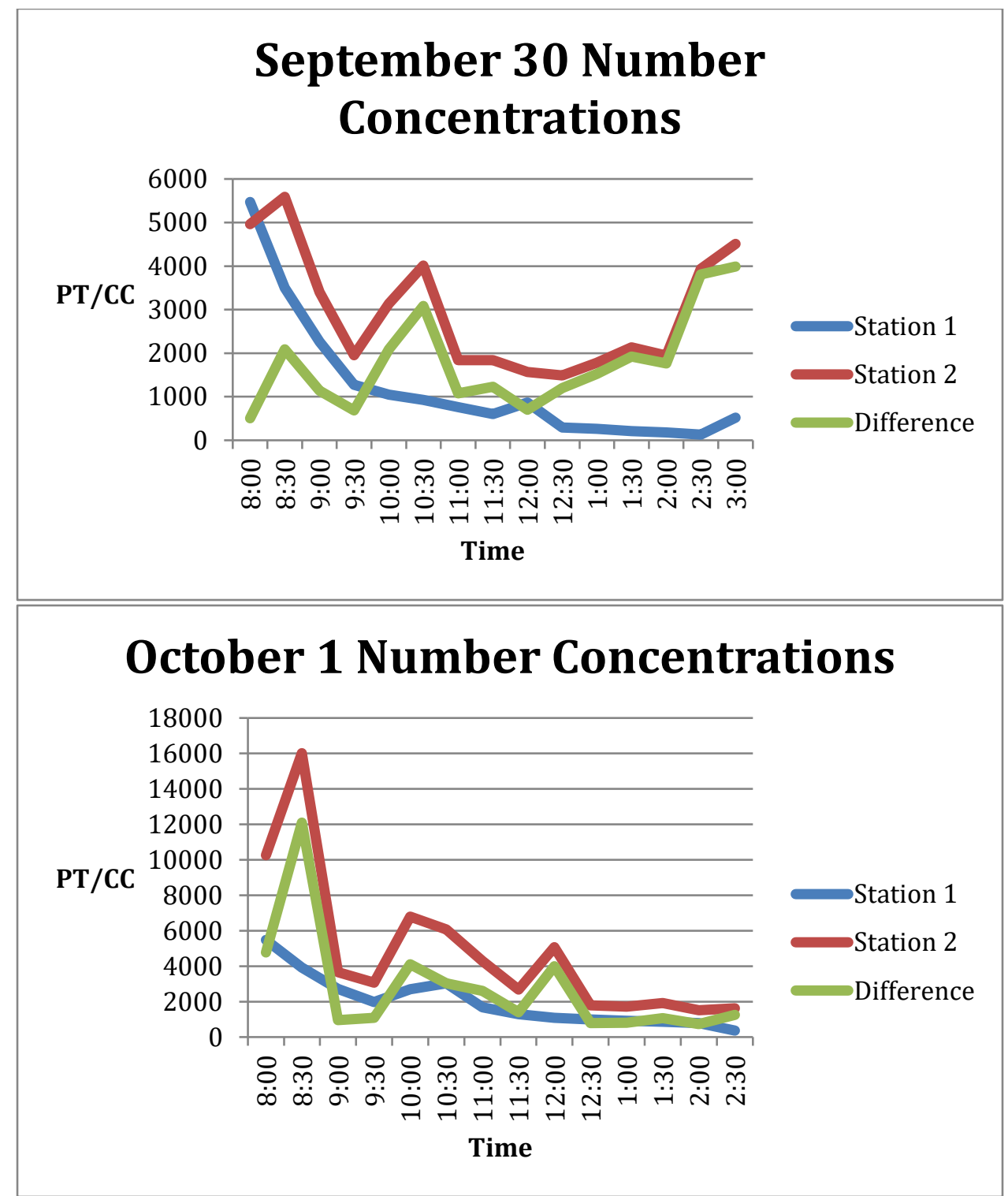




\section{October 2 Number Concentrations}

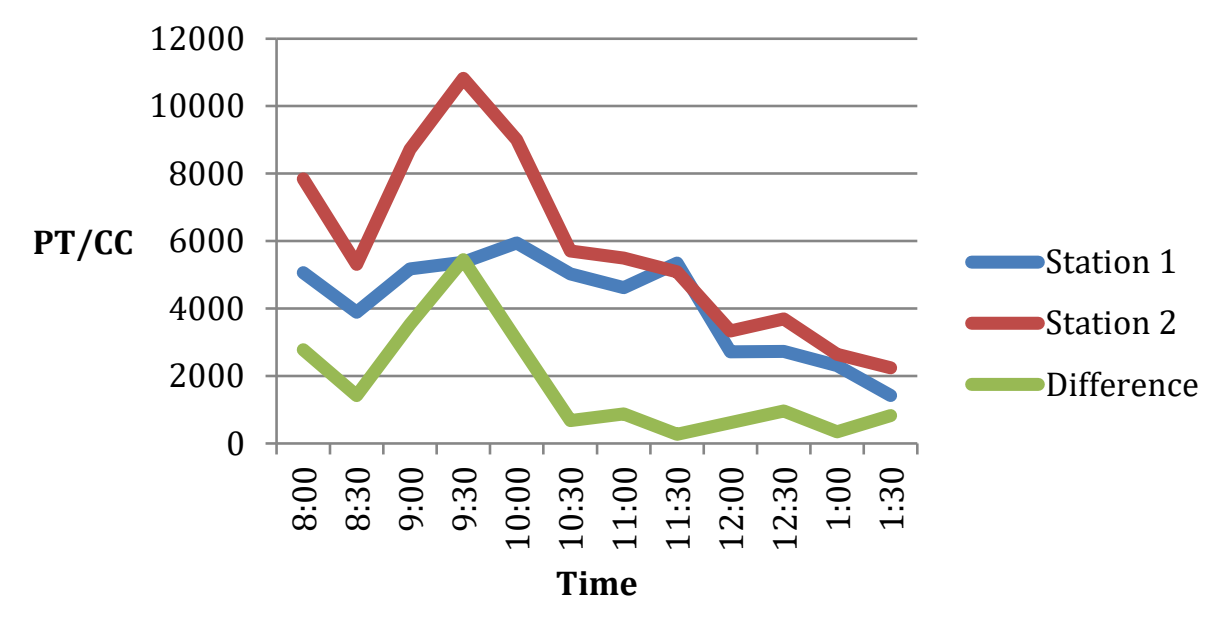

\section{October 3 Number Concentrations}

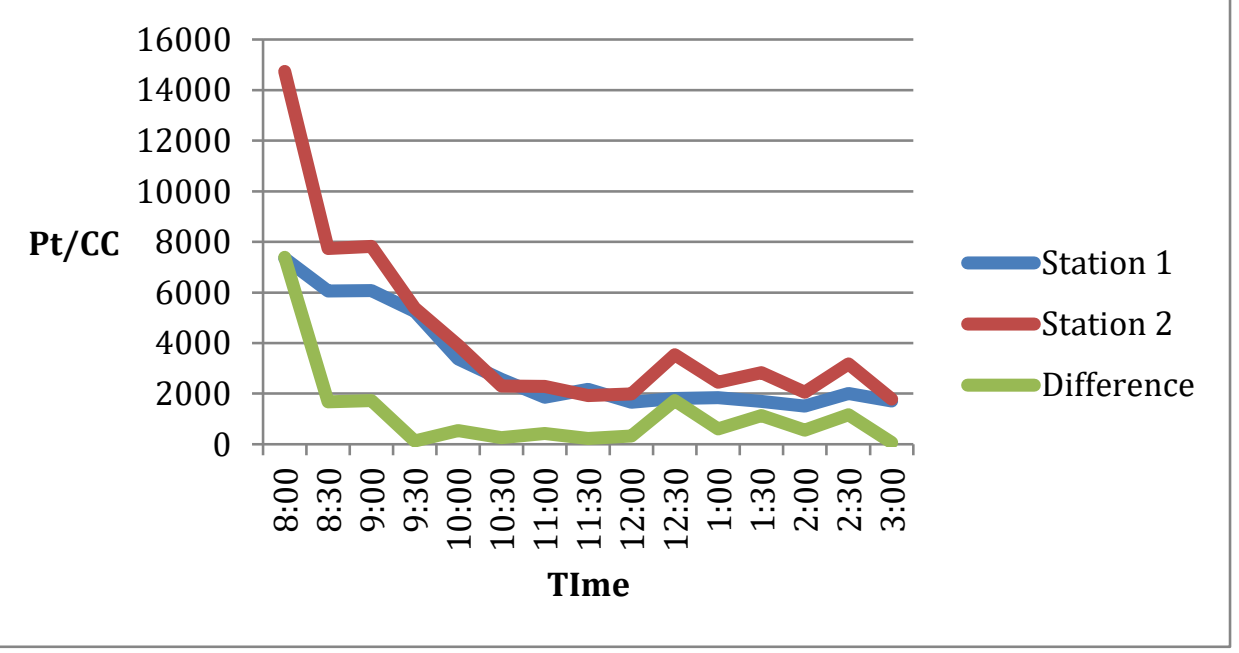



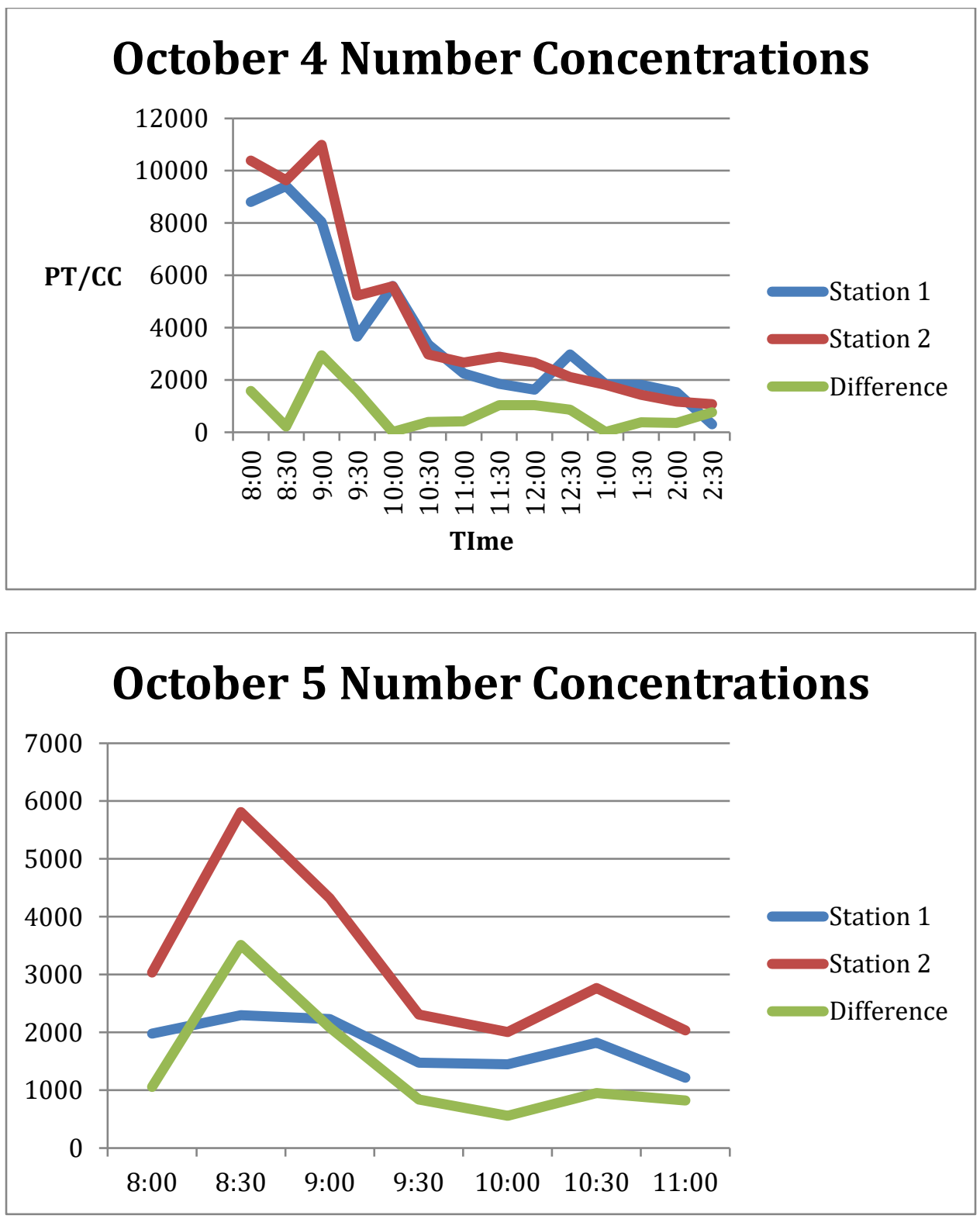

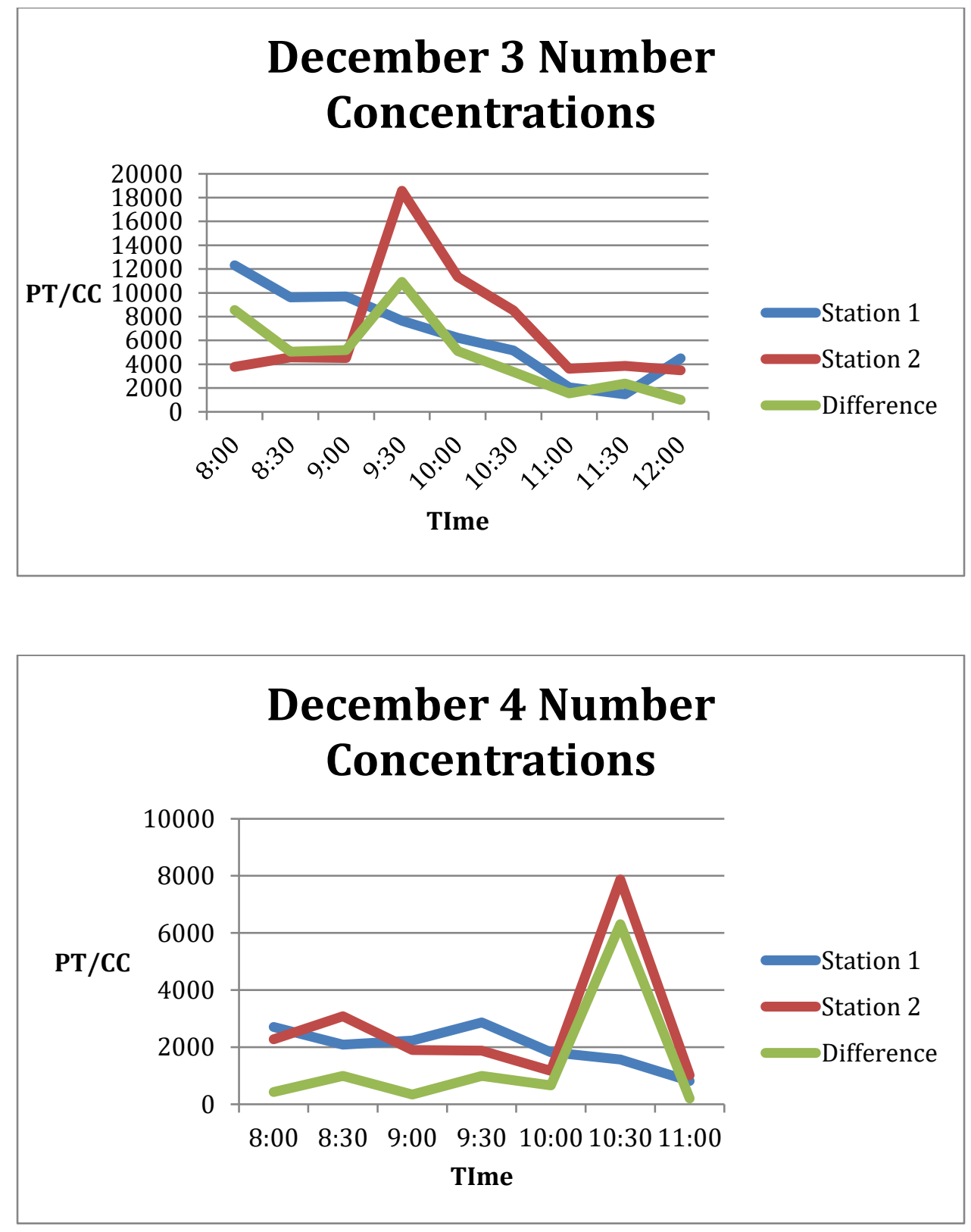

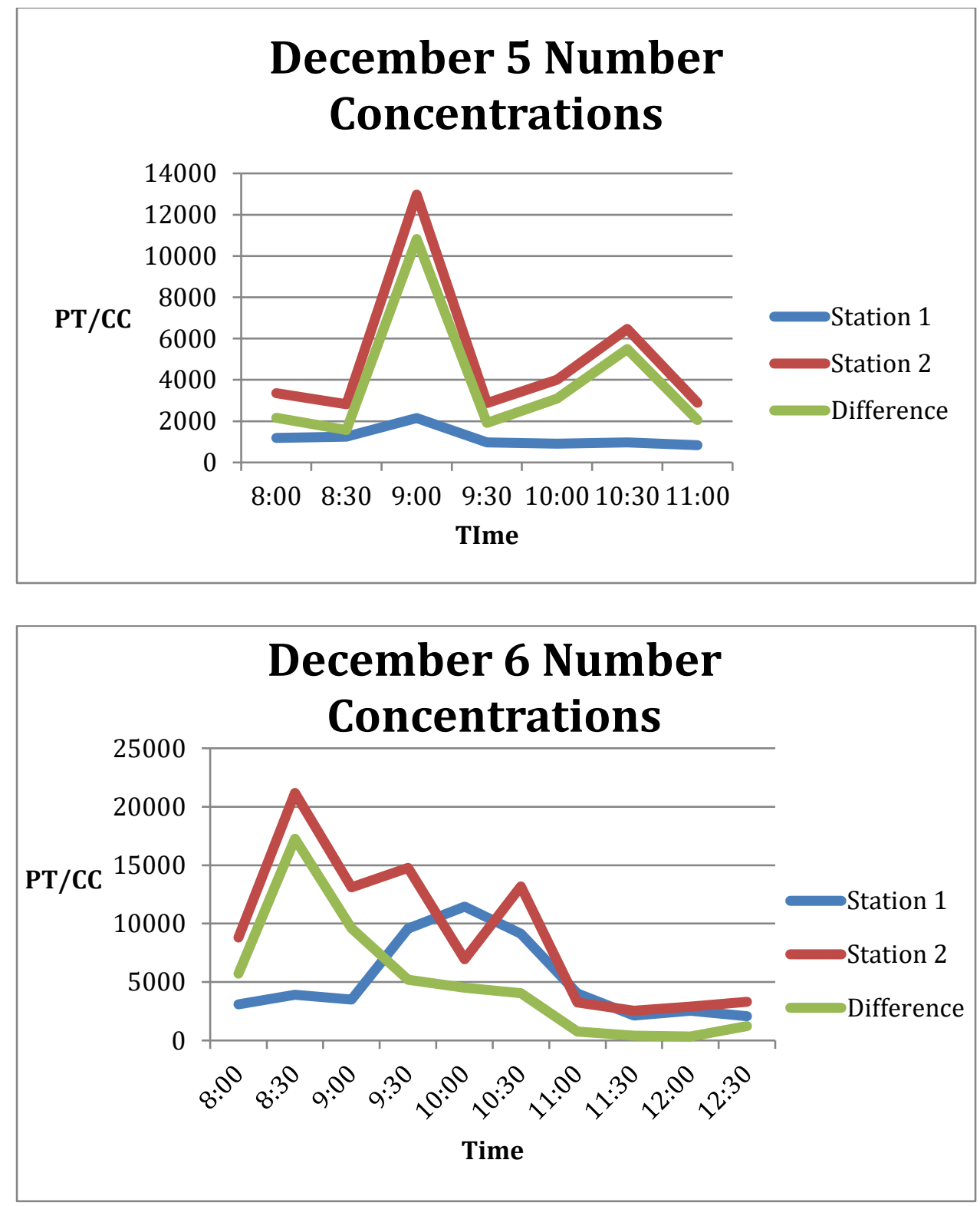


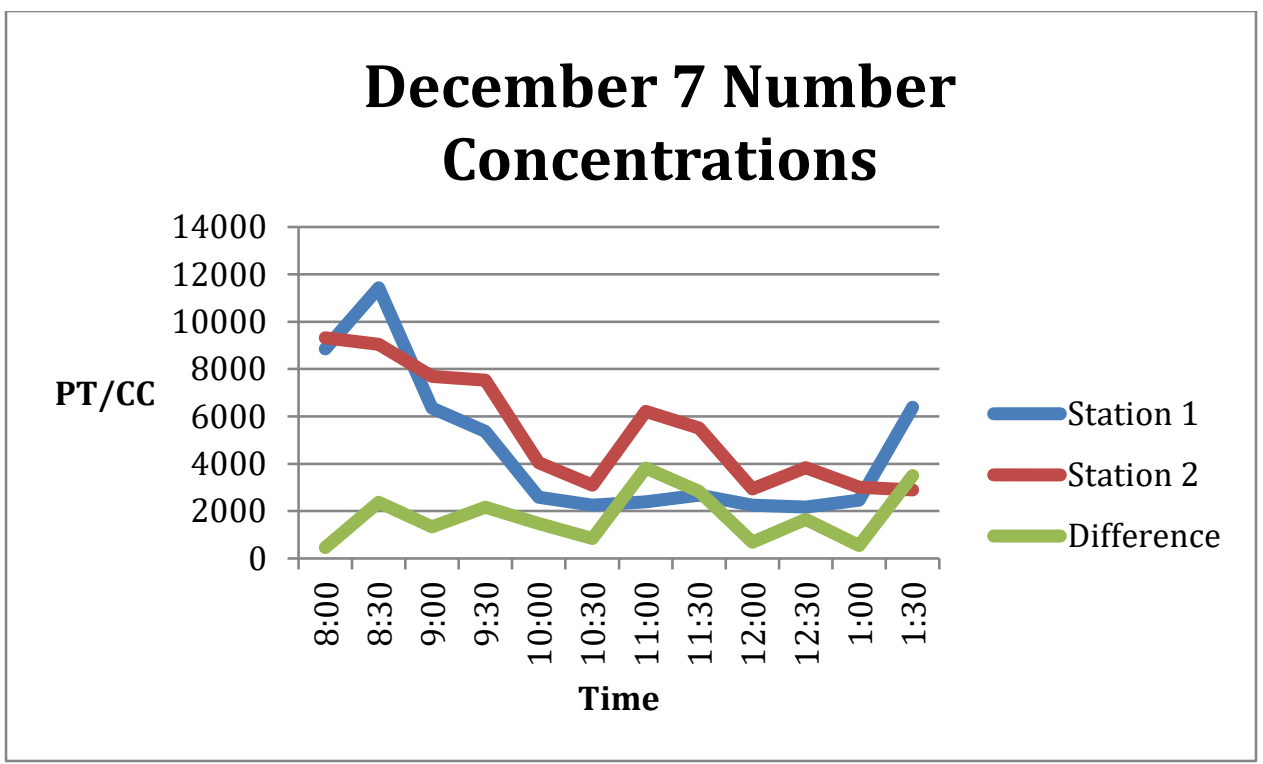




\section{Appendix B: Atmospheric Stability}

\begin{tabular}{|c|c|c|c|c|c|}
\hline \multicolumn{5}{|c|}{ Atmospheric Stability (September $\mathbf{2 0})$} \\
\hline Time & Valley $\left(\mathbf{F}^{\circ}\right)$ & Mountain $\left(\mathbf{F}^{\circ}\right)$ & $\Delta \mathbf{T}\left(\mathbf{F}^{\circ}\right)$ & $\Delta \mathbf{T}\left(\mathbf{K}^{\circ}\right)$ & $\mathbf{K}^{\circ}$ /Elevation(m) \\
\hline $7: 50$ & 67 & 65 & -2 & 254.04 & 1.18 \\
\hline $8: 10$ & 68 & 65 & -3 & 292.93 & 1.36 \\
\hline $8: 30$ & 68 & 65 & -3 & 292.93 & 1.36 \\
\hline $8: 50$ & 68 & 66 & -2 & 293.09 & 1.36 \\
\hline $9: 15$ & 69 & 67 & -2 & 293.46 & 1.36 \\
\hline $9: 30$ & 70 & 68 & -2 & 294.15 & 1.37 \\
\hline $9: 50$ & 71 & 71 & 0 & 294.65 & 1.37 \\
\hline $10: 10$ & 72 & 73 & 1 & 295.40 & 1.37 \\
\hline $10: 30$ & 73 & 75 & 2 & 296.15 & 1.38 \\
\hline $10: 50$ & 76 & 76 & 0 & 297.76 & 1.38 \\
\hline $11: 10$ & 79 & 79 & 0 & 299.01 & 1.39 \\
\hline $11: 30$ & 81 & 81 & 1 & 300.09 & 1.40 \\
\hline $11: 50$ & 82 & 82 & 0 & 301.09 & 1.40 \\
\hline $12: 10$ & 84 & 82 & -2 & 301.96 & 1.40 \\
\hline $12: 30$ & 85 & 84 & -1 & 302.76 & 1.41 \\
\hline $12: 50$ & 86 & 85 & -1 & 303.29 & 1.41 \\
\hline $13: 10$ & 88 & 81 & -7 & 303.98 & 1.41 \\
\hline $13: 35$ & 88 & 83 & -5 & 304.51 & 1.42 \\
\hline $13: 50$ & 90 & 84 & -6 & 305.15 & 1.42 \\
\hline $14: 10$ & 89 & 85 & -4 & 305.04 & 1.42 \\
\hline $14: 30$ & 79 & 86 & 7 & 299.01 & 1.39 \\
\hline $14: 55$ & 90 & 84 & -6 & 305.32 & 1.42 \\
\hline $15: 10$ & 89 & -5 & 304.65 & 1.42 \\
\hline & & & & & \\
\hline
\end{tabular}




\begin{tabular}{|c|c|c|c|c|c|}
\hline \multicolumn{6}{|c|}{ Atmospheric Stability (September 21) } \\
\hline Time & Valley $\left(\mathrm{F}^{\circ}\right)$ & Mountain $\left(\mathrm{F}^{\circ}\right)$ & $\Delta T\left(F^{\circ}\right)$ & $\Delta \mathrm{T}\left(\mathrm{K}^{\circ}\right)$ & $\mathrm{K}^{\circ} /$ Elevation $(\mathrm{m})$ \\
\hline $7: 50$ & 67 & 65 & -2 & 254.04 & 1.18 \\
\hline $8: 10$ & 68 & 66 & -2 & 292.93 & 1.36 \\
\hline $8: 30$ & 68 & 67 & -1 & 292.93 & 1.36 \\
\hline $8: 50$ & 68 & 67 & -1 & 293.09 & 1.36 \\
\hline 9:15 & 69 & 70 & 1 & 293.46 & 1.36 \\
\hline 9:30 & 70 & 72 & 2 & 294.15 & 1.37 \\
\hline 9:50 & 71 & 75 & 4 & 294.65 & 1.37 \\
\hline 10:10 & 72 & 77 & 5 & 295.40 & 1.37 \\
\hline $10: 30$ & 73 & 77 & 4 & 296.15 & 1.38 \\
\hline $10: 50$ & 76 & 78 & 2 & 297.76 & 1.38 \\
\hline 11:10 & 79 & 80 & 1 & 299.01 & 1.39 \\
\hline $11: 30$ & 81 & 81 & 1 & 300.09 & 1.40 \\
\hline $11: 50$ & 82 & 82 & 0 & 301.09 & 1.40 \\
\hline $12: 10$ & 84 & 83 & -1 & 301.96 & 1.40 \\
\hline $12: 30$ & 85 & 83 & -2 & 302.76 & 1.41 \\
\hline $12: 50$ & 86 & 84 & -2 & 303.29 & 1.41 \\
\hline $13: 10$ & 88 & 85 & -3 & 303.98 & 1.41 \\
\hline $13: 35$ & 88 & 86 & -2 & 304.51 & 1.42 \\
\hline $13: 50$ & 90 & 86 & -4 & 305.15 & 1.42 \\
\hline $14: 10$ & 89 & 86 & -3 & 305.04 & 1.42 \\
\hline $14: 30$ & 79 & 86 & 7 & 299.01 & 1.39 \\
\hline $14: 55$ & 90 & 86 & -4 & 305.32 & 1.42 \\
\hline $15: 10$ & 89 & 81 & -8 & 304.65 & 1.42 \\
\hline
\end{tabular}




\begin{tabular}{|c|c|c|c|c|c|}
\hline \multicolumn{6}{|c|}{ Atmospheric Stability (September 29) } \\
\hline Time & Valley $\left(\mathbf{F}^{\circ}\right)$ & Mountain $\left(\mathrm{F}^{\circ}\right)$ & $\Delta T\left(F^{\circ}\right)$ & $\Delta \mathrm{T}\left(\mathrm{K}^{\circ}\right)$ & $\mathrm{K}^{\circ} /$ Elevation $(\mathrm{m})$ \\
\hline $7: 50$ & 64 & 57 & -7 & 251.29 & 1.17 \\
\hline $8: 10$ & 66 & 58 & -8 & 292.07 & 1.36 \\
\hline $8: 30$ & 68 & 58 & -10 & 293.26 & 1.36 \\
\hline $8: 50$ & 69 & 59 & -10 & 293.43 & 1.36 \\
\hline $9: 15$ & 70 & 59 & -11 & 294.01 & 1.37 \\
\hline $9: 30$ & 70 & 60 & -10 & 294.23 & 1.37 \\
\hline $9: 50$ & 71 & 61 & -10 & 294.90 & 1.37 \\
\hline 10:10 & 71 & 61 & -10 & 295.07 & 1.37 \\
\hline $10: 30$ & 71 & 63 & -8 & 294.76 & 1.37 \\
\hline $10: 50$ & 71 & 64 & -7 & 295.07 & 1.37 \\
\hline $11: 10$ & 73 & 64 & -9 & 295.65 & 1.38 \\
\hline $11: 30$ & 74 & 66 & -8 & 296.65 & 1.38 \\
\hline $11: 50$ & 74 & 67 & -7 & 296.51 & 1.38 \\
\hline $12: 10$ & 75 & 68 & -7 & 296.90 & 1.38 \\
\hline $12: 30$ & 75 & 71 & -4 & 296.98 & 1.38 \\
\hline $12: 50$ & 75 & 71 & -4 & 297.29 & 1.38 \\
\hline $13: 10$ & 75 & 71 & -4 & 296.76 & 1.38 \\
\hline $13: 35$ & 74 & 71 & -3 & 296.40 & 1.38 \\
\hline $13: 50$ & 74 & 71 & -3 & 296.51 & 1.38 \\
\hline $14: 10$ & 74 & 71 & -3 & 296.32 & 1.38 \\
\hline $14: 30$ & 73 & 70 & -3 & 295.65 & 1.38 \\
\hline $14: 55$ & 70 & 69 & -1 & 294.15 & 1.37 \\
\hline
\end{tabular}




\begin{tabular}{|c|c|c|c|c|c|}
\hline \multicolumn{6}{|c|}{ Atmospheric Stability (September $\mathbf{3 0})$} \\
\hline Time & Valley $\left(\mathbf{F}^{\circ}\right)$ & Mountain $\left(\mathbf{F}^{\circ}\right)$ & $\Delta \mathbf{T}\left(\mathbf{F}^{\circ}\right)$ & $\Delta \mathbf{T}\left(\mathbf{K}^{\circ}\right)$ & $\mathbf{K}^{\circ} /$ Elevation$(\mathbf{m})$ \\
\hline $7: 50$ & 57 & 55 & -2 & 254.21 & 1.18 \\
\hline $8: 10$ & 57 & 55 & -2 & 287.21 & 1.34 \\
\hline $8: 30$ & 58 & 56 & -2 & 287.59 & 1.34 \\
\hline $8: 50$ & 59 & 57 & -2 & 288.26 & 1.34 \\
\hline $9: 15$ & 60 & 60 & 0 & 288.79 & 1.34 \\
\hline $9: 30$ & 61 & 63 & 2 & 289.46 & 1.35 \\
\hline $9: 50$ & 63 & 65 & 2 & 290.40 & 1.35 \\
\hline $10: 10$ & 65 & 69 & 4 & 291.62 & 1.36 \\
\hline $10: 30$ & 67 & 72 & 5 & 292.73 & 1.36 \\
\hline $10: 50$ & 69 & 73 & 4 & 293.79 & 1.37 \\
\hline $11: 10$ & 71 & 72 & 1 & 295.01 & 1.37 \\
\hline $11: 30$ & 73 & 74 & 1 & 296.12 & 1.38 \\
\hline $11: 50$ & 76 & 75 & -1 & 297.82 & 1.39 \\
\hline $12: 10$ & 79 & 77 & -2 & 299.01 & 1.39 \\
\hline $12: 30$ & 79 & 77 & -2 & 299.15 & 1.39 \\
\hline $12: 50$ & 80 & 78 & -2 & 299.65 & 1.39 \\
\hline $13: 10$ & 81 & 76 & -5 & 300.09 & 1.40 \\
\hline $13: 35$ & 81 & 78 & -3 & 300.40 & 1.40 \\
\hline $13: 50$ & 82 & 80 & -2 & 300.76 & 1.40 \\
\hline $14: 10$ & 82 & 80 & -2 & 301.15 & 1.40 \\
\hline $14: 30$ & 81 & 81 & 0 & 300.57 & 1.40 \\
\hline $14: 55$ & 83 & 81 & -2 & 301.65 & 1.40 \\
\hline
\end{tabular}




\begin{tabular}{|c|c|c|c|c|c|}
\hline \multicolumn{6}{|c|}{ Atmospheric Stability (October 1) } \\
\hline Time & Valley $\left(F^{\circ}\right)$ & Mountain $\left(\mathrm{F}^{\circ}\right)$ & $\Delta T\left(F^{\circ}\right)$ & $\Delta \mathrm{T}\left(\mathrm{K}^{\circ}\right)$ & $\mathrm{K}^{\circ} /$ Elevation(m) \\
\hline $7: 50$ & 62 & 60 & -2 & 254.15 & 1.18 \\
\hline $8: 10$ & 62 & 60 & -2 & 289.98 & 1.35 \\
\hline $8: 30$ & 63 & 60 & -3 & 290.21 & 1.35 \\
\hline $8: 50$ & 63 & 61 & -2 & 290.46 & 1.35 \\
\hline $9: 15$ & 64 & 63 & -1 & 290.96 & 1.35 \\
\hline $9: 30$ & 65 & 64 & -1 & 291.57 & 1.36 \\
\hline $9: 50$ & 66 & 66 & 0 & 291.98 & 1.36 \\
\hline $10: 10$ & 67 & 69 & 2 & 292.57 & 1.36 \\
\hline $10: 30$ & 72 & 71 & -1 & 295.51 & 1.37 \\
\hline 10:50 & 74 & 74 & 1 & 296.21 & 1.38 \\
\hline $11: 10$ & 77 & 73 & -4 & 298.04 & 1.39 \\
\hline $11: 30$ & 78 & 76 & -2 & 298.43 & 1.39 \\
\hline $11: 50$ & 79 & 77 & -2 & 299.23 & 1.39 \\
\hline $12: 10$ & 80 & 78 & -2 & 299.76 & 1.39 \\
\hline $12: 30$ & 79 & 77 & -2 & 299.46 & 1.39 \\
\hline $12: 50$ & 79 & 78 & -1 & 299.51 & 1.39 \\
\hline $13: 10$ & 80 & 78 & -2 & 299.96 & 1.40 \\
\hline $13: 35$ & 81 & 76 & -5 & 300.29 & 1.40 \\
\hline $13: 50$ & 81 & 81 & 1 & 300.09 & 1.40 \\
\hline
\end{tabular}




\begin{tabular}{|c|c|c|c|c|c|}
\hline \multicolumn{7}{|c|}{ Atmospheric Stability (October $\mathbf{2})$} \\
\hline Time & Valley $\left(\mathbf{F}^{\circ}\right)$ & Mountain $\left(\mathbf{F}^{\circ}\right)$ & $\Delta \mathbf{T}\left(\mathbf{F}^{\circ}\right)$ & $\Delta \mathbf{T}\left(\mathbf{K}^{\circ}\right)$ & $\mathbf{K}^{\circ} /$ Elevation $(\mathbf{m})$ \\
\hline $7: 50$ & 65 & 63 & -2 & 254.15 & 1.18 \\
\hline $8: 10$ & 65 & 64 & -1 & 291.71 & 1.36 \\
\hline $8: 30$ & 66 & 64 & -2 & 291.90 & 1.36 \\
\hline $8: 50$ & 66 & 65 & -1 & 292.15 & 1.36 \\
\hline $9: 15$ & 67 & 65 & -2 & 292.32 & 1.36 \\
\hline $9: 30$ & 67 & 66 & -1 & 292.43 & 1.36 \\
\hline $9: 50$ & 67 & 67 & 0 & 292.43 & 1.36 \\
\hline $10: 10$ & 67 & 67 & 0 & 292.48 & 1.36 \\
\hline $10: 30$ & 67 & 67 & 0 & 292.76 & 1.36 \\
\hline $10: 50$ & 68 & 67 & -1 & 293.09 & 1.36 \\
\hline $11: 10$ & 69 & 68 & -1 & 293.46 & 1.36 \\
\hline $11: 30$ & 70 & 69 & -1 & 294.21 & 1.37 \\
\hline $11: 50$ & 71 & 69 & -2 & 294.84 & 1.37 \\
\hline $12: 10$ & 72 & 70 & -2 & 295.32 & 1.37 \\
\hline $12: 30$ & 72 & 70 & -2 & 295.48 & 1.37 \\
\hline $12: 50$ & 72 & 70 & -2 & 295.48 & 1.37 \\
\hline $13: 10$ & 73 & 70 & -3 & 295.82 & 1.38 \\
\hline $13: 35$ & 73 & 71 & -2 & 295.93 & 1.38 \\
\hline $13: 50$ & 73 & 73 & 0 & 295.98 & 1.38 \\
\hline
\end{tabular}




\begin{tabular}{|c|c|c|c|c|c|}
\hline \multicolumn{7}{|c|}{ Atmospheric Stability (October 3$)$} \\
\hline Time & Valley $\left(\mathbf{F}^{\circ}\right)$ & Mountain $\left(\mathbf{F}^{\circ}\right)$ & $\Delta \mathbf{T}\left(\mathbf{F}^{\circ}\right)$ & $\Delta \mathbf{T}\left(\mathbf{K}^{\circ}\right)$ & $\mathbf{K}^{\circ} /$ Elevation $(\mathbf{m})$ \\
\hline $7: 50$ & 66 & 65 & -1 & 254.65 & 1.18 \\
\hline $8: 10$ & 67 & 66 & -1 & 292.32 & 1.36 \\
\hline $8: 30$ & 67 & 66 & -1 & 292.59 & 1.36 \\
\hline $8: 50$ & 68 & 67 & -1 & 293.09 & 1.36 \\
\hline $9: 15$ & 69 & 69 & 0 & 293.73 & 1.37 \\
\hline $9: 30$ & 70 & 71 & 1 & 294.40 & 1.37 \\
\hline $9: 50$ & 71 & 72 & 1 & 294.98 & 1.37 \\
\hline $10: 10$ & 72 & 71 & -1 & 295.51 & 1.37 \\
\hline $10: 30$ & 74 & 72 & -2 & 296.21 & 1.38 \\
\hline $10: 50$ & 73 & 72 & -1 & 295.96 & 1.38 \\
\hline $11: 10$ & 73 & 73 & 0 & 296.01 & 1.38 \\
\hline $11: 30$ & 76 & 73 & -3 & 297.65 & 1.38 \\
\hline $11: 50$ & 77 & 76 & -1 & 298.04 & 1.39 \\
\hline $12: 10$ & 79 & 77 & -2 & 299.01 & 1.39 \\
\hline $12: 30$ & 79 & 78 & -1 & 299.15 & 1.39 \\
\hline $12: 50$ & 81 & 79 & -2 & 300.21 & 1.40 \\
\hline $13: 10$ & 82 & 79 & -3 & 300.90 & 1.40 \\
\hline $13: 35$ & 80 & 80 & 0 & 299.96 & 1.40 \\
\hline $13: 50$ & 81 & 81 & 0 & 300.59 & 1.40 \\
\hline
\end{tabular}




\begin{tabular}{|c|c|c|c|c|c|}
\hline \multicolumn{7}{|c|}{ Atmospheric Stability (October $\mathbf{4})$} \\
\hline Time & Valley $\left(\mathbf{F}^{\circ}\right)$ & Mountain $\left(\mathbf{F}^{\circ}\right)$ & $\Delta \mathbf{T}\left(\mathbf{F}^{\circ}\right)$ & $\Delta \mathbf{T}\left(\mathbf{K}^{\circ}\right)$ & $\mathbf{K}^{\circ} /$ Elevation$(\mathbf{m})$ \\
\hline $7: 50$ & 64 & 62 & -2 & 254.48 & 1.18 \\
\hline $8: 10$ & 64 & 62 & -2 & 290.82 & 1.35 \\
\hline $8: 30$ & 64 & 63 & -1 & 290.98 & 1.35 \\
\hline $8: 50$ & 65 & 64 & -1 & 291.26 & 1.35 \\
\hline $9: 15$ & 65 & 65 & 0 & 291.73 & 1.36 \\
\hline $9: 30$ & 67 & 66 & -1 & 292.40 & 1.36 \\
\hline $9: 50$ & 68 & 67 & -1 & 293.07 & 1.36 \\
\hline $10: 10$ & 70 & 70 & 0 & 294.51 & 1.37 \\
\hline $10: 30$ & 73 & 72 & -1 & 295.65 & 1.38 \\
\hline $10: 50$ & 75 & 75 & 0 & 296.79 & 1.38 \\
\hline $11: 10$ & 77 & 76 & -1 & 298.21 & 1.39 \\
\hline $11: 30$ & 79 & 78 & -1 & 299.34 & 1.39 \\
\hline $11: 50$ & 80 & 79 & -1 & 299.98 & 1.40 \\
\hline $12: 10$ & 80 & 78 & -2 & 299.87 & 1.39 \\
\hline $12: 30$ & 82 & 80 & -2 & 300.84 & 1.40 \\
\hline $12: 50$ & 83 & 81 & -2 & 301.40 & 1.40 \\
\hline $13: 10$ & 84 & 80 & -4 & 302.01 & 1.40 \\
\hline $13: 35$ & 85 & 81 & -4 & 302.54 & 1.41 \\
\hline $13: 50$ & 85 & 81 & -4 & 302.54 & 1.41 \\
\hline
\end{tabular}




\begin{tabular}{|c|c|c|c|c|c|}
\hline \multicolumn{6}{|c|}{ Atmospheric Stability (October 5$)$} \\
\hline Time & Valley $\left(\mathbf{F}^{\circ}\right)$ & Mountain $\left(\mathbf{F}^{\circ}\right)$ & $\Delta \mathbf{T}\left(\mathbf{F}^{\circ}\right)$ & $\Delta \mathbf{T}\left(\mathbf{K}^{\circ}\right)$ & $\mathbf{K}^{\circ} /$ Elevation $(\mathbf{m})$ \\
\hline $7: 50$ & 70 & 70 & 0 & 255.43 & 1.19 \\
\hline $8: 10$ & 70 & 70 & 0 & 294.32 & 1.37 \\
\hline $8: 30$ & 70 & 70 & 0 & 294.48 & 1.37 \\
\hline $8: 50$ & 71 & 70 & -1 & 294.59 & 1.37 \\
\hline $9: 15$ & 71 & 71 & 0 & 294.71 & 1.37 \\
\hline $9: 30$ & 71 & 72 & 1 & 295.07 & 1.37 \\
\hline $9: 50$ & 72 & 72 & 0 & 295.46 & 1.37 \\
\hline $10: 10$ & 72 & 73 & 1 & 295.59 & 1.37 \\
\hline $10: 30$ & 73 & 72 & -1 & 295.96 & 1.38 \\
\hline $10: 50$ & 74 & 73 & -1 & 296.43 & 1.38 \\
\hline
\end{tabular}

\begin{tabular}{|c|c|c|c|c|c|}
\hline \multicolumn{7}{|c|}{ Atmospheric Stability (December 3$)$} \\
\hline Time & Valley $\left(\mathbf{F}^{\circ}\right)$ & Mountain $\left(\mathbf{F}^{\circ}\right)$ & $\Delta \mathbf{T}\left(\mathbf{F}^{\circ}\right)$ & $\Delta \mathbf{T}\left(\mathbf{K}^{\circ}\right)$ & $\mathbf{K}^{\circ} /$ Elevation $(\mathbf{m})$ \\
\hline $7: 50$ & 42 & 39 & -3 & 253.90 & 1.18 \\
\hline $8: 10$ & 41 & 39 & -2 & 277.93 & 1.29 \\
\hline $8: 30$ & 43 & 40 & -3 & 279.48 & 1.30 \\
\hline $8: 50$ & 46 & 43 & -3 & 280.68 & 1.31 \\
\hline $9: 15$ & 46 & 46 & 0 & 281.15 & 1.31 \\
\hline $9: 30$ & 47 & 47 & 0 & 281.46 & 1.31 \\
\hline $9: 50$ & 47 & 47 & 0 & 281.65 & 1.31 \\
\hline $10: 10$ & 47 & 47 & 0 & 281.68 & 1.31 \\
\hline $10: 30$ & 48 & 48 & 0 & 281.93 & 1.31 \\
\hline $10: 50$ & 48 & 48 & 0 & 282.23 & 1.31 \\
\hline $11: 10$ & 48.9 & 47 & -2 & 282.54 & 1.31 \\
\hline
\end{tabular}




\begin{tabular}{|c|c|c|c|c|c|}
\hline \multicolumn{6}{|c|}{ Atmospheric Stability (December 4) } \\
\hline Time & Valley $\left(\mathbf{F}^{\circ}\right)$ & Mountain $\left(\mathbf{F}^{\circ}\right)$ & $\Delta \mathbf{T}\left(\mathbf{F}^{\circ}\right)$ & $\Delta \mathbf{T}\left(\mathbf{K}^{\circ}\right)$ & $\mathbf{K}^{\circ} /$ Elevation $(\mathbf{m})$ \\
\hline $7: 50$ & 36 & 34 & -2 & 254.04 & 1.18 \\
\hline $8: 10$ & 37 & 34 & -3 & 275.90 & 1.28 \\
\hline $8: 30$ & 37 & 34 & -3 & 275.98 & 1.28 \\
\hline $8: 50$ & 37 & 35 & -2 & 276.15 & 1.28 \\
\hline $9: 15$ & 38 & 35 & -3 & 276.32 & 1.29 \\
\hline $9: 30$ & 38 & 34 & -4 & 276.48 & 1.29 \\
\hline $9: 50$ & 38 & 34 & -4 & 276.71 & 1.29 \\
\hline $10: 10$ & 38 & 33 & -5 & 276.59 & 1.29 \\
\hline $10: 30$ & 38 & 33 & -5 & 276.59 & 1.29 \\
\hline $10: 50$ & 38 & 34 & -4 & 276.65 & 1.29 \\
\hline $11: 10$ & 38 & 34 & -4 & 276.48 & 1.29 \\
\hline
\end{tabular}

\begin{tabular}{|c|c|c|c|c|c|}
\hline \multicolumn{6}{|c|}{ Atmospheric Stability (December 5$)$} \\
\hline Time & Valley $\left(\mathbf{F}^{\circ}\right)$ & Mountain $\left(\mathbf{F}^{\circ}\right)$ & $\Delta \mathbf{T}\left(\mathbf{F}^{\circ}\right)$ & $\Delta \mathbf{T}\left(\mathbf{K}^{\circ}\right)$ & $\mathbf{K}^{\circ} /$ Elevation $(\mathbf{m})$ \\
\hline $7: 50$ & 32 & 30 & -2 & 254.09 & 1.18 \\
\hline $8: 10$ & 32 & 30 & -2 & 273.40 & 1.27 \\
\hline $8: 30$ & 33 & 30 & -3 & 273.59 & 1.27 \\
\hline $8: 50$ & 33 & 30 & -3 & 273.82 & 1.27 \\
\hline $9: 15$ & 33 & 30 & -3 & 273.90 & 1.27 \\
\hline $9: 30$ & 34 & 30 & -4 & 274.15 & 1.28 \\
\hline $9: 50$ & 34 & 31 & -3 & 274.37 & 1.28 \\
\hline $10: 10$ & 35 & 31 & -4 & 274.57 & 1.28 \\
\hline $10: 30$ & 35 & 31 & -4 & 274.57 & 1.28 \\
\hline $10: 50$ & 34 & 31 & -3 & 274.15 & 1.28 \\
\hline $11: 10$ & 34 & 31 & -3 & 274.26 & 1.28 \\
\hline
\end{tabular}




\begin{tabular}{|c|c|c|c|c|c|}
\hline \multicolumn{6}{|c|}{ Atmospheric Stability (December 7) } \\
\hline Time & Valley $\left(\mathrm{F}^{\circ}\right)$ & Mountain $\left(\mathrm{F}^{\circ}\right)$ & $\Delta \mathrm{T}\left(\mathrm{F}^{\circ}\right)$ & $\Delta \mathrm{T}\left(\mathrm{K}^{\circ}\right)$ & $\mathrm{K}^{\circ} /$ Elevation $(\mathrm{m})$ \\
\hline 7:50 & 36 & 34 & -2 & 254.15 & 1.18 \\
\hline $8: 10$ & 37 & 35 & -2 & 275.96 & 1.28 \\
\hline $8: 30$ & 38 & 35 & -3 & 276.21 & 1.28 \\
\hline $8: 50$ & 38 & 35 & -3 & 276.40 & 1.29 \\
\hline 9:15 & 39 & 36 & -3 & 276.76 & 1.29 \\
\hline 9:30 & 39 & 36 & -3 & 276.90 & 1.29 \\
\hline 9:50 & 39 & 36 & -3 & 276.87 & 1.29 \\
\hline 10:10 & 39 & 36 & -3 & 277.15 & 1.29 \\
\hline $10: 30$ & 39 & 36 & -3 & 276.98 & 1.29 \\
\hline 10:50 & 39 & 36 & -3 & 276.90 & 1.29 \\
\hline 11:10 & 39 & 37 & -2 & 277.09 & 1.29 \\
\hline 11:30 & 40 & 37 & -3 & 277.59 & 1.29 \\
\hline $11: 50$ & 41 & 37 & -4 & 278.09 & 1.29 \\
\hline $12: 10$ & 41 & 38 & -3 & 278.04 & 1.29 \\
\hline $12: 30$ & 41 & 38 & -3 & 277.93 & 1.29 \\
\hline $12: 50$ & 41 & 37 & -4 & 277.96 & 1.29 \\
\hline $13: 10$ & 41 & 37 & -4 & 278.21 & 1.29 \\
\hline
\end{tabular}




\section{Appendix C: Number Concentrations for each Days Sampling}

\begin{tabular}{|c|c|c|c|c|c|c|c|c|c|c|c|c|c|c|}
\hline \multirow[b]{2}{*}{ Time } & \multicolumn{2}{|c|}{ 20-Sep } & \multicolumn{2}{|c|}{ 21-Sep } & \multicolumn{2}{|c|}{ 29-Sep } & \multicolumn{2}{|c|}{ 30-Sep } & \multicolumn{2}{|c|}{ 1-Oct } & \multicolumn{2}{|c|}{ 2-0ct } & \multicolumn{2}{|c|}{ 3-0ct } \\
\hline & $\begin{array}{c}\text { Station } \\
1\end{array}$ & $\begin{array}{c}\text { Station } \\
2\end{array}$ & $\begin{array}{c}\text { Station } \\
1\end{array}$ & $\begin{array}{c}\text { Station } \\
2\end{array}$ & $\begin{array}{c}\text { Station } \\
1\end{array}$ & $\begin{array}{c}\text { Station } \\
2\end{array}$ & $\begin{array}{c}\text { Station } \\
1\end{array}$ & $\begin{array}{l}\text { Station } \\
2\end{array}$ & $\begin{array}{c}\text { Station } \\
1\end{array}$ & $\begin{array}{c}\text { Station } \\
2\end{array}$ & $\begin{array}{c}\text { Station } \\
1\end{array}$ & $\begin{array}{c}\text { Station } \\
2\end{array}$ & $\begin{array}{c}\text { Station } \\
1\end{array}$ & $\begin{array}{l}\text { Station } \\
2\end{array}$ \\
\hline $\begin{array}{c}8: 00: 00 \\
\text { AM }\end{array}$ & 7489 & 4987 & 1673 & 3599 & 1594 & 1134 & 5104 & 6419 & 3127 & 4122 & 5230 & 9062 & 7562 & 7233 \\
\hline $\begin{array}{c}8: 01: 00 \\
\text { AM }\end{array}$ & 6400 & 4721 & 1713 & 3408 & 1966 & 1013 & 4570 & 6866 & 3119 & 7005 & 5525 & 8329 & 6224 & 7808 \\
\hline $\begin{array}{c}8: 02: 00 \\
\text { AM }\end{array}$ & 5738 & 5169 & 2874 & 3626 & 2689 & 1147 & 4892 & 6861 & 3132 & 7198 & 5911 & 8151 & 3735 & 6744 \\
\hline $\begin{array}{c}8: 03: 00 \\
\text { AM }\end{array}$ & 4978 & 4768 & 3439 & 3383 & 1538 & 1152 & 5748 & 5825 & 3130 & 10197 & 5873 & 8164 & 4251 & 7559 \\
\hline $\begin{array}{c}8: 04: 00 \\
\text { AM }\end{array}$ & 4685 & 4507 & 4333 & 2766 & 1553 & 1179 & 4191 & 5990 & 3101 & 10267 & 5321 & 7469 & 4533 & 7554 \\
\hline $\begin{array}{c}8: 05: 00 \\
\text { AM }\end{array}$ & 4289 & 4867 & 5103 & 2951 & 1820 & 1182 & 5235 & 5944 & 3058 & 7247 & 5556 & 8018 & 4674 & 8046 \\
\hline $\begin{array}{c}8: 06: 00 \\
\text { AM }\end{array}$ & 3969 & 3595 & 5542 & 3139 & 2434 & 1163 & 5832 & 5759 & 2995 & 6491 & 5730 & 8206 & 4722 & 7925 \\
\hline $\begin{array}{c}8: 07: 00 \\
\text { AM }\end{array}$ & 3785 & 3396 & 5825 & 2975 & 1738 & 1119 & 3192 & 5478 & 2924 & 7327 & 5908 & 9241 & 4641 & 8318 \\
\hline $\begin{array}{c}8: 08: 00 \\
\text { AM }\end{array}$ & 3549 & 3353 & 8714 & 2979 & 1486 & 1123 & 2763 & 5240 & 2888 & 9495 & 6853 & 11679 & 4648 & 8873 \\
\hline $\begin{array}{c}8: 09: 00 \\
\text { AM }\end{array}$ & 3378 & 4061 & 9412 & 2933 & 1481 & 1069 & 3599 & 4913 & 2915 & 8794 & 6929 & 10675 & 4728 & 9736 \\
\hline $\begin{array}{c}8: 10: 00 \\
\text { AM }\end{array}$ & 3269 & 5369 & 8052 & 2763 & 1492 & 1118 & 4589 & 4653 & 2988 & 8594 & 6959 & 9962 & 4915 & 11155 \\
\hline $\begin{array}{c}8: 11: 00 \\
\text { AM }\end{array}$ & 3262 & 5129 & 6820 & 2833 & 1765 & 1279 & 5062 & 4358 & 3038 & 12280 & 7075 & 9383 & 4844 & 16692 \\
\hline $\begin{array}{c}8: 12: 00 \\
\text { AM }\end{array}$ & 3031 & 4853 & 6027 & 3016 & 1802 & 1371 & 4965 & 4029 & 3024 & 13875 & 6850 & 9918 & 4754 & 11670 \\
\hline $\begin{array}{c}8: 13: 00 \\
\text { AM }\end{array}$ & 2969 & 5470 & 6168 & 3069 & 1299 & 1425 & 5996 & 4047 & 7100 & 13185 & 6106 & 9640 & 7244 & 7456 \\
\hline $\begin{array}{c}8: 14: 00 \\
\text { AM }\end{array}$ & 2896 & 6124 & 6745 & 3037 & 1295 & 1358 & 8367 & 4068 & 8413 & 14180 & 5338 & 9248 & 7678 & 7471 \\
\hline $\begin{array}{c}8: 15: 00 \\
\text { AM }\end{array}$ & 2848 & 5232 & 7331 & 2908 & 1321 & 1360 & 8445 & 3963 & 7833 & 14855 & 5020 & 9344 & 8274 & 16213 \\
\hline $\begin{array}{c}8: 16: 00 \\
\text { AM }\end{array}$ & 2866 & 4682 & 4507 & 2852 & 1408 & 1387 & 6993 & 4015 & 6624 & 11015 & 4392 & 9407 & 8813 & 16943 \\
\hline $\begin{array}{c}8: 17: 00 \\
\text { AM }\end{array}$ & 2862 & 4755 & 6032 & 2872 & 1290 & 1399 & 7863 & 4134 & 6798 & 6981 & 4076 & 9393 & 10597 & 8258 \\
\hline $\begin{array}{c}8: 18: 00 \\
\text { AM }\end{array}$ & 2807 & 4945 & 5728 & 2868 & 1232 & 1388 & 6920 & 4058 & 5527 & 6796 & 4048 & 8470 & 13115 & 15922 \\
\hline $\begin{array}{c}8: 19: 00 \\
\text { AM }\end{array}$ & 3003 & 5141 & 6870 & 2830 & 1186 & 1388 & 4944 & 4200 & 6440 & 5634 & 3907 & 6856 & 9848 & 19335 \\
\hline $\begin{array}{c}8: 20: 00 \\
\text { AM }\end{array}$ & 3088 & 4807 & 5892 & 2807 & 1113 & 1372 & 5007 & 4243 & 6227 & 6570 & 4125 & 6519 & 5186 & 13273 \\
\hline $\begin{array}{c}8: 21: 00 \\
\text { AM }\end{array}$ & 3112 & 5803 & 5010 & 2738 & 1047 & 1362 & 3947 & 4217 & 7619 & 6817 & 4098 & 5461 & 5656 & 15632 \\
\hline $\begin{array}{c}8: 22: 00 \\
\text { AM }\end{array}$ & 3146 & 5625 & 3836 & 2614 & 1059 & 1357 & 3233 & 4177 & 7890 & 9443 & 3942 & 5345 & 11484 & 16125 \\
\hline $\begin{array}{c}8: 23: 00 \\
\text { AM }\end{array}$ & 3142 & 5767 & 3898 & 2578 & 1064 & 1367 & 4314 & 3998 & 7716 & 9915 & 3980 & 5210 & 11507 & 22338 \\
\hline $\begin{array}{c}8: 24: 00 \\
\text { AM }\end{array}$ & 3102 & 7563 & 3857 & 2622 & 1056 & 1373 & 4424 & 3911 & 7941 & 11078 & 4127 & 5202 & 11333 & 37523 \\
\hline $\begin{array}{c}8: 25: 00 \\
\text { AM }\end{array}$ & 3064 & 6519 & 3516 & 2661 & 1023 & 1413 & 5733 & 3887 & 7859 & 11582 & 4226 & 5086 & 9592 & 37060 \\
\hline $\begin{array}{c}8: 26: 00 \\
\text { AM }\end{array}$ & 3123 & 7649 & 3405 & 2664 & 1001 & 1460 & 6874 & 3864 & 7479 & 12613 & 4422 & 5611 & 9787 & 16860 \\
\hline $\begin{array}{c}8: 27: 00 \\
\text { AM }\end{array}$ & 3222 & 8799 & 3236 & 2983 & 1011 & 1494 & 7287 & 6611 & 7761 & 16005 & 3668 & 5563 & 9791 & 20229 \\
\hline
\end{tabular}




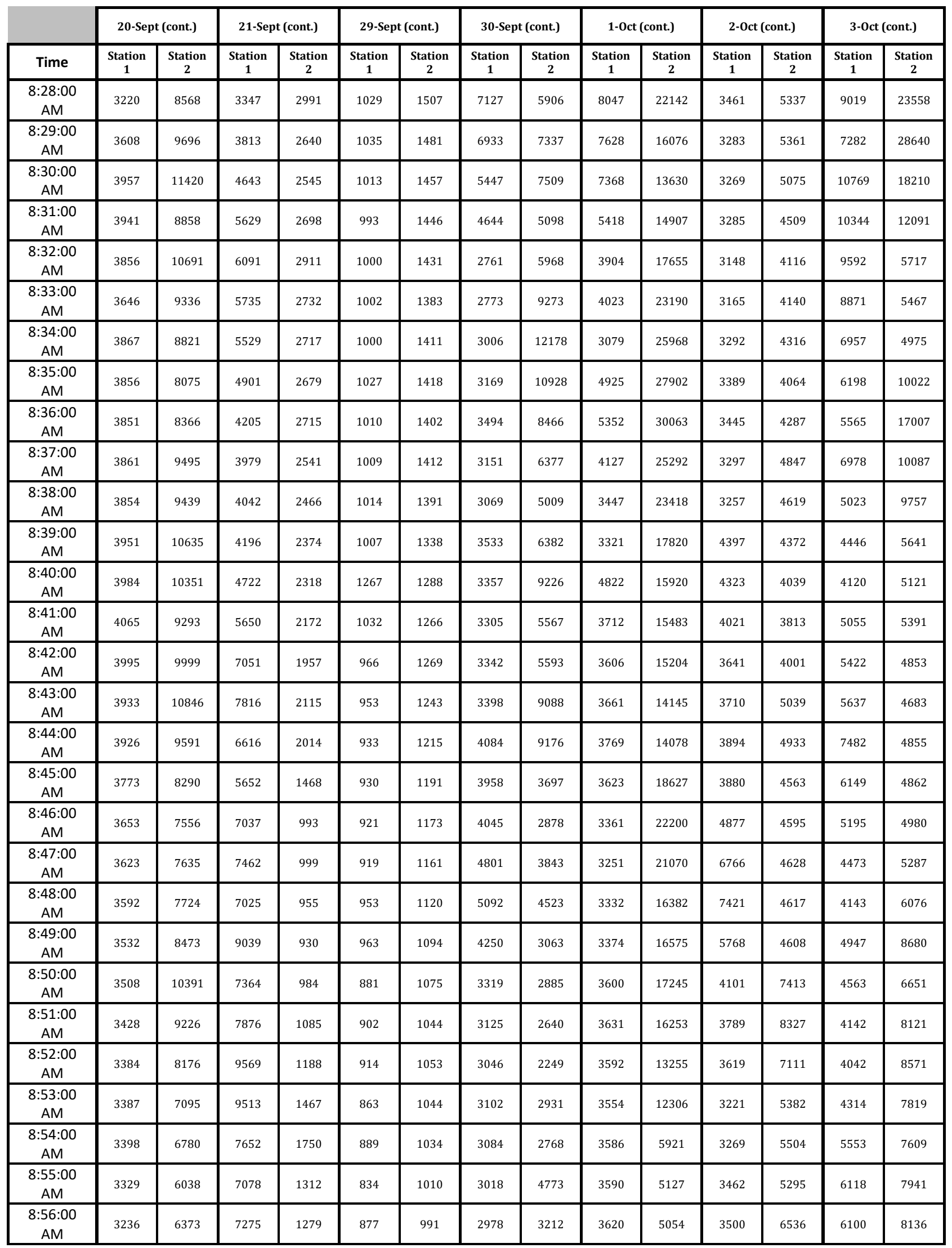




\begin{tabular}{|c|c|c|c|c|c|c|c|c|c|c|c|c|c|c|}
\hline \multirow[b]{2}{*}{ Time } & \multicolumn{2}{|c|}{ 20-Sept (cont.) } & \multicolumn{2}{|c|}{ 21-Sept (cont.) } & \multicolumn{2}{|c|}{ 29-Sept (cont.) } & \multicolumn{2}{|c|}{ 30-Sept (cont.) } & \multicolumn{2}{|c|}{ 1-Oct (cont.) } & \multicolumn{2}{|c|}{ 2-Oct (cont.) } & \multicolumn{2}{|c|}{ 3-Oct (cont.) } \\
\hline & $\begin{array}{c}\text { Station } \\
1\end{array}$ & $\begin{array}{c}\text { Station } \\
2\end{array}$ & $\begin{array}{c}\text { Station } \\
1\end{array}$ & $\begin{array}{c}\text { Station } \\
2\end{array}$ & $\begin{array}{c}\text { Station } \\
1\end{array}$ & $\begin{array}{c}\text { Station } \\
2\end{array}$ & $\begin{array}{c}\text { Station } \\
1\end{array}$ & $\begin{array}{c}\text { Station } \\
2\end{array}$ & $\begin{array}{c}\text { Station } \\
1\end{array}$ & $\begin{array}{c}\text { Station } \\
2\end{array}$ & $\begin{array}{c}\text { Station } \\
1\end{array}$ & $\begin{array}{c}\text { Station } \\
2\end{array}$ & $\begin{array}{c}\text { Station } \\
1\end{array}$ & $\begin{array}{c}\text { Station } \\
2\end{array}$ \\
\hline $\begin{array}{c}8: 57: 00 \\
\text { AM }\end{array}$ & 3119 & 6347 & 8552 & 1422 & 811 & 964 & 2911 & 3130 & 3590 & 5428 & 3451 & 9326 & 6555 & 8277 \\
\hline $\begin{array}{c}8: 58: 00 \\
\text { AM }\end{array}$ & 3458 & 6108 & 6472 & 308 & 834 & 937 & 2919 & 3459 & 3633 & 5409 & 3166 & 7149 & 6614 & 7662 \\
\hline $\begin{array}{c}9: 00: 00 \\
\text { AM }\end{array}$ & 3259 & 6235 & 5476 & 354 & 799 & 871 & 2871 & 4849 & 3659 & 4893 & 3121 & 6664 & 6588 & 7232 \\
\hline $\begin{array}{c}9: 01: 00 \\
\text { AM }\end{array}$ & 3307 & 6471 & 4775 & 373 & 808 & 855 & 2836 & 6765 & 3658 & 4811 & 3173 & 7430 & 6671 & 7381 \\
\hline $\begin{array}{c}9: 02: 00 \\
\text { AM }\end{array}$ & 3290 & 7138 & 4950 & 370 & 767 & 844 & 2820 & 11545 & 3576 & 4661 & 3192 & 5745 & 6010 & 8127 \\
\hline $\begin{array}{c}9: 04: 00 \\
\text { AM }\end{array}$ & 3393 & 7863 & 6033 & 445 & 764 & 812 & 2750 & 3740 & 3477 & 5441 & 3031 & 4984 & 4281 & 8055 \\
\hline $\begin{array}{c}9: 05: 00 \\
\text { AM }\end{array}$ & 3420 & 7182 & 5531 & 446 & 877 & 799 & 2423 & 4581 & 3221 & 4758 & 5123 & 5379 & 4210 & 7401 \\
\hline $\begin{array}{c}9: 06: 00 \\
\text { AM }\end{array}$ & 3386 & 6457 & 4878 & 451 & 1017 & 809 & 2492 & 5268 & 3008 & 4370 & 7606 & 5583 & 4604 & 7656 \\
\hline $\begin{array}{c}9: 07: 00 \\
\text { AM }\end{array}$ & 3289 & 6166 & 4282 & 464 & 943 & 803 & 2549 & 5186 & 2797 & 4126 & 7797 & 4977 & 4394 & 8215 \\
\hline $\begin{array}{c}9: 08: 00 \\
\text { AM }\end{array}$ & 3278 & 6064 & 4250 & 458 & 916 & 791 & 2518 & 2569 & 3048 & 3852 & 9662 & 5001 & 4237 & 9011 \\
\hline $\begin{array}{c}9: 09: 00 \\
\text { AM }\end{array}$ & 2865 & 8030 & 4453 & 464 & 837 & 775 & 2361 & 2239 & 3009 & 3431 & 9358 & 5740 & 4295 & 8017 \\
\hline $\begin{array}{c}9: 10: 00 \\
\text { AM }\end{array}$ & 2896 & 9229 & 5308 & 461 & 1007 & 757 & 2303 & 2347 & 2929 & 3759 & 11356 & 14843 & 4294 & 7465 \\
\hline $\begin{array}{c}9: 12: 00 \\
\text { AM }\end{array}$ & 3037 & 9487 & 5062 & 423 & 883 & 746 & 2344 & 2119 & 2762 & 3577 & 7833 & 11236 & 4335 & 7183 \\
\hline $\begin{array}{c}9: 13: 00 \\
\text { AM }\end{array}$ & 2965 & 8062 & 4290 & 436 & 835 & 740 & 2387 & 2273 & 2740 & 3383 & 6610 & 14240 & 4555 & 7210 \\
\hline $\begin{array}{c}9: 14: 00 \\
\text { AM }\end{array}$ & 2879 & 7935 & 3958 & 418 & 854 & 752 & 2369 & 2158 & 2721 & 3296 & 6788 & 14723 & 5125 & 6641 \\
\hline $\begin{array}{c}9: 15: 00 \\
\text { AM }\end{array}$ & 2850 & 7458 & 4278 & 452 & 828 & 749 & 2349 & 2317 & 2554 & 3298 & 6058 & 16557 & 4671 & 6513 \\
\hline $\begin{array}{c}9: 16: 00 \\
\text { AM }\end{array}$ & 2872 & 6570 & 3901 & 398 & 866 & 744 & 2311 & 2672 & 2461 & 3205 & 5391 & 15083 & 6580 & 6597 \\
\hline $\begin{array}{c}9: 17: 00 \\
\text { AM }\end{array}$ & 2808 & 9145 & 3511 & 394 & 836 & 767 & 2229 & 2760 & 2559 & 3362 & 5220 & 13733 & 8012 & 6472 \\
\hline $\begin{array}{c}9: 18: 00 \\
\text { AM }\end{array}$ & 2775 & 5821 & 3537 & 404 & 836 & 754 & 2176 & 2703 & 2488 & 3412 & 4118 & 11727 & 7782 & 7028 \\
\hline $\begin{array}{c}9: 19: 00 \\
\text { AM }\end{array}$ & 2729 & 8682 & 3469 & 410 & 1322 & 743 & 2124 & 3683 & 2592 & 4022 & 2729 & 10343 & 7702 & 8399 \\
\hline $\begin{array}{c}9: 20: 00 \\
\text { AM }\end{array}$ & 2714 & 13338 & 3126 & 418 & 1684 & 759 & 2127 & 3451 & 2538 & 3304 & 2658 & 11378 & 7772 & 9673 \\
\hline $\begin{array}{c}9: 21: 00 \\
\text { AM }\end{array}$ & 2695 & 16413 & 2842 & 423 & 1168 & 758 & 2119 & 3308 & 2328 & 3329 & 3289 & 10403 & 7457 & 9057 \\
\hline $\begin{array}{c}9: 22: 00 \\
\text { AM }\end{array}$ & 2899 & 14313 & 2925 & 400 & 975 & 774 & 2049 & 2797 & 2184 & 3396 & 3227 & 7609 & 6470 & 9525 \\
\hline $\begin{array}{c}9: 23: 00 \\
\text { AM }\end{array}$ & 2995 & 11705 & 2978 & 394 & 819 & 755 & 1851 & 2391 & 2149 & 2900 & 3222 & 6061 & 6251 & 7197 \\
\hline $\begin{array}{c}9: 24: 00 \\
\text { AM }\end{array}$ & 2681 & 5659 & 3027 & 392 & 783 & 759 & 1660 & 2264 & 2097 & 2732 & 2978 & 3453 & 6301 & 9341 \\
\hline $\begin{array}{c}9: 25: 00 \\
\text { AM }\end{array}$ & 2650 & 5653 & 3183 & 366 & 820 & 749 & 1611 & 2480 & 2151 & 2795 & 3069 & 3972 & 7336 & 7602 \\
\hline
\end{tabular}




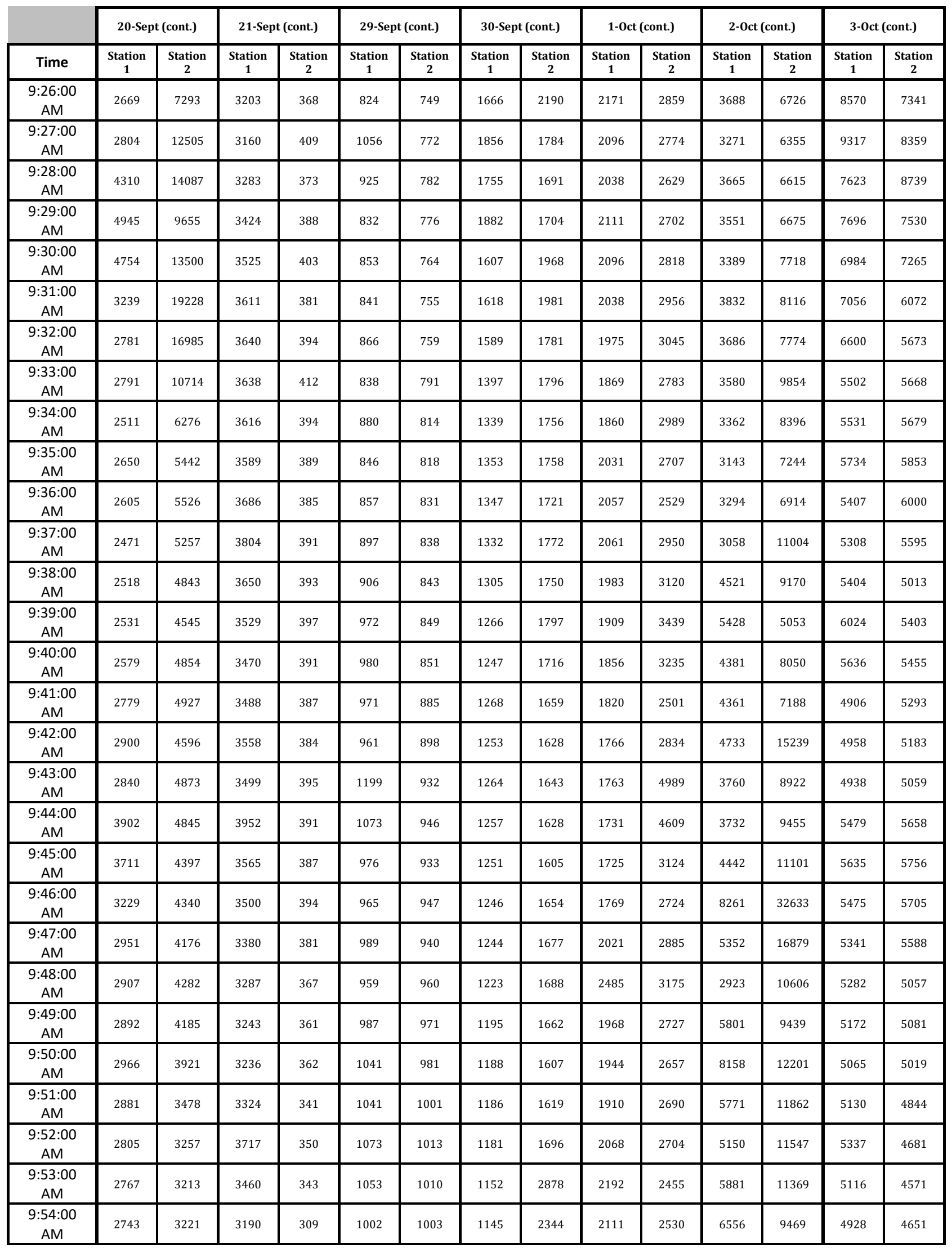




\begin{tabular}{|c|c|c|c|c|c|c|c|c|c|c|c|c|c|c|}
\hline \multirow[b]{2}{*}{ Time } & \multicolumn{2}{|c|}{ 20-Sept (cont.) } & \multicolumn{2}{|c|}{ 21-Sept (cont.) } & \multicolumn{2}{|c|}{ 29-Sept (cont.) } & \multicolumn{2}{|c|}{ 30-Sept (cont.) } & \multicolumn{2}{|c|}{ 1-Oct (cont.) } & \multicolumn{2}{|c|}{ 2-oct (cont.) } & \multicolumn{2}{|c|}{ 3-Oct (cont.) } \\
\hline & $\begin{array}{c}\text { Station } \\
1\end{array}$ & $\begin{array}{l}\text { Station } \\
2\end{array}$ & $\begin{array}{c}\text { Station } \\
1\end{array}$ & $\begin{array}{l}\text { Station } \\
2\end{array}$ & $\begin{array}{c}\text { Station } \\
1\end{array}$ & $\begin{array}{c}\text { Station } \\
2\end{array}$ & $\begin{array}{c}\text { Station } \\
1\end{array}$ & $\begin{array}{l}\text { Station } \\
2\end{array}$ & $\begin{array}{c}\text { Station } \\
1\end{array}$ & $\begin{array}{l}\text { Station } \\
2\end{array}$ & $\begin{array}{c}\text { Station } \\
1\end{array}$ & $\begin{array}{c}\text { Station } \\
2\end{array}$ & $\begin{array}{c}\text { Station } \\
1\end{array}$ & $\begin{array}{c}\text { Station } \\
2\end{array}$ \\
\hline $\begin{array}{c}9: 55: 00 \\
\text { AM }\end{array}$ & 4289 & 3293 & 3197 & 380 & 1330 & 1003 & 1136 & 2687 & 2039 & 2837 & 8276 & 8153 & 4589 & 4496 \\
\hline $\begin{array}{c}9: 56: 00 \\
\text { AM }\end{array}$ & 3154 & 7164 & 3188 & 372 & 1521 & 993 & 1152 & 2173 & 1985 & 2740 & 9658 & 13394 & 3810 & 4378 \\
\hline $\begin{array}{c}9: 57: 00 \\
\text { AM }\end{array}$ & 4091 & 7470 & 3216 & 311 & 2006 & 991 & 1140 & 3777 & 2018 & 3177 & 7749 & 15618 & 3707 & 4428 \\
\hline $\begin{array}{c}9: 58: 00 \\
\text { AM }\end{array}$ & 3165 & 7392 & 3461 & 387 & 2326 & 996 & 1135 & 2756 & 2021 & 3704 & 8820 & 9842 & 3827 & 4721 \\
\hline $\begin{array}{c}9: 59: 00 \\
\text { AM }\end{array}$ & 4207 & 5814 & 4207 & 356 & 1852 & 1007 & 1128 & 2519 & 2030 & 4176 & 10225 & 10552 & 3796 & 7522 \\
\hline $\begin{array}{c}\text { 10:00:00 } \\
\text { AM }\end{array}$ & 3836 & 4161 & 4939 & 302 & 1692 & 1013 & 1130 & 4441 & 2128 & 3802 & 9598 & 11905 & 3485 & 10865 \\
\hline $\begin{array}{c}\text { 10:01:00 } \\
\text { AM }\end{array}$ & 3254 & 3841 & 7346 & 375 & 1977 & 1039 & 1111 & 13079 & 2189 & 3806 & 10439 & 12612 & 3470 & 8134 \\
\hline $\begin{array}{c}10: 02: 00 \\
\text { AM }\end{array}$ & 2682 & 3598 & 9822 & 367 & 1746 & 1093 & 1108 & 8773 & 2264 & 3930 & 7198 & 14467 & 3486 & 5095 \\
\hline $\begin{array}{c}10: 03: 00 \\
\text { AM }\end{array}$ & 3203 & 3611 & 13797 & 354 & 1362 & 1065 & 1112 & 3107 & 2274 & 4282 & 7903 & 12020 & 3324 & 4563 \\
\hline $\begin{array}{c}10: 04: 00 \\
\text { AM }\end{array}$ & 3369 & 3907 & 19168 & 337 & 1201 & 1036 & 1103 & 2389 & 2334 & 4454 & 7586 & 10597 & 3093 & 3921 \\
\hline $\begin{array}{c}10: 05: 00 \\
\text { AM }\end{array}$ & 3566 & 3844 & 15384 & 359 & 1168 & 1047 & 1088 & 2648 & 2323 & 3968 & 9293 & 10554 & 2773 & 3733 \\
\hline $\begin{array}{c}10: 06: 00 \\
\text { AM }\end{array}$ & 3485 & 4667 & 14240 & 404 & 1114 & 1076 & 1093 & 2572 & 2290 & 3828 & 6355 & 12652 & 2651 & 3569 \\
\hline $\begin{array}{c}10: 07: 00 \\
\text { AM }\end{array}$ & 3012 & 5074 & 12732 & 340 & 1156 & 1079 & 1094 & 4268 & 2295 & 6509 & 7131 & 11140 & 2619 & 3308 \\
\hline $\begin{array}{c}\text { 10:08:00 } \\
\text { AM }\end{array}$ & 3248 & 4056 & 9402 & 412 & 1269 & 1089 & 1092 & 2862 & 2479 & 8702 & 6256 & 9692 & 2501 & 3170 \\
\hline $\begin{array}{c}10: 09: 00 \\
\text { AM }\end{array}$ & 3066 & 3886 & 10201 & 352 & 1250 & 1077 & 1085 & 4248 & 2801 & 6142 & 5751 & 8109 & 2451 & 3161 \\
\hline $\begin{array}{c}10: 10: 00 \\
\text { AM }\end{array}$ & 2723 & 3835 & 19073 & 336 & 1206 & 1068 & 1086 & 2325 & 2571 & 5362 & 4577 & 7445 & 2368 & 3083 \\
\hline $\begin{array}{c}\text { 10:11:00 } \\
\text { AM }\end{array}$ & 2587 & 3688 & 23591 & 334 & 1166 & 1090 & 1080 & 2972 & 2543 & 5874 & 4157 & 6725 & 2284 & 3202 \\
\hline $\begin{array}{c}10: 12: 00 \\
\text { AM }\end{array}$ & 2365 & 3714 & 23027 & 344 & 1180 & 1100 & 1076 & 1887 & 2610 & 5164 & 5256 & 7214 & 2292 & 3499 \\
\hline $\begin{array}{c}10: 13: 00 \\
\text { AM }\end{array}$ & 2370 & 3743 & 21507 & 346 & 1181 & 1094 & 1065 & 2373 & 2572 & 4034 & 5844 & 8012 & 2221 & 3136 \\
\hline $\begin{array}{c}10: 14: 00 \\
\text { AM }\end{array}$ & 2363 & 3701 & 19793 & 350 & 1202 & 1082 & 1052 & 3336 & 2766 & 4030 & 6076 & 12519 & 2215 & 2890 \\
\hline $\begin{array}{c}10: 15: 00 \\
\text { AM }\end{array}$ & 2388 & 3751 & 17427 & 344 & 1265 & 1077 & 1043 & 2537 & 2790 & 3978 & 5980 & 13283 & 2292 & 3026 \\
\hline $\begin{array}{c}10: 16: 00 \\
\text { AM }\end{array}$ & 2334 & 3751 & 10472 & 358 & 1400 & 1069 & 1031 & 2494 & 2833 & 4383 & 5840 & 9693 & 2303 & 3218 \\
\hline $\begin{array}{c}10: 17: 00 \\
\text { AM }\end{array}$ & 2224 & 3762 & 5491 & 352 & 1168 & 1060 & 1030 & 2222 & 2846 & 4171 & 5413 & 9557 & 2366 & 3664 \\
\hline $\begin{array}{c}\text { 10:18:00 } \\
\text { AM }\end{array}$ & 2148 & 3775 & 8329 & 352 & 1163 & 1068 & 1008 & 2143 & 2914 & 6565 & 4728 & 9474 & 2409 & 3719 \\
\hline $\begin{array}{c}\text { 10:19:00 } \\
\text { AM }\end{array}$ & 2090 & 3776 & 8586 & 494 & 1127 & 1057 & 1007 & 2076 & 3098 & 12008 & 4367 & 7248 & 2456 & 3363 \\
\hline $\begin{array}{c}10: 20: 00 \\
\text { AM }\end{array}$ & 2060 & 3624 & 8724 & 306 & 1102 & 1076 & 1009 & 1719 & 2974 & 12415 & 4229 & 7106 & 2469 & 2948 \\
\hline $\begin{array}{c}\text { 10:21:00 } \\
\text { AM }\end{array}$ & 1873 & 3673 & 8679 & 331 & 1263 & 1083 & 1026 & 1768 & 2974 & 12015 & 3857 & 6884 & 2452 & 2854 \\
\hline $\begin{array}{c}10: 22: 00 \\
\text { AM }\end{array}$ & 1904 & 4024 & 6519 & 361 & 1191 & 1087 & 1006 & 2397 & 2969 & 11795 & 4776 & 7224 & 2504 & 3054 \\
\hline $\begin{array}{c}10: 23: 00 \\
\text { AM }\end{array}$ & 1987 & 4284 & 4631 & 362 & 1202 & 1088 & 1009 & 2779 & 2976 & 11900 & 5332 & 6621 & 2581 & 6922 \\
\hline
\end{tabular}




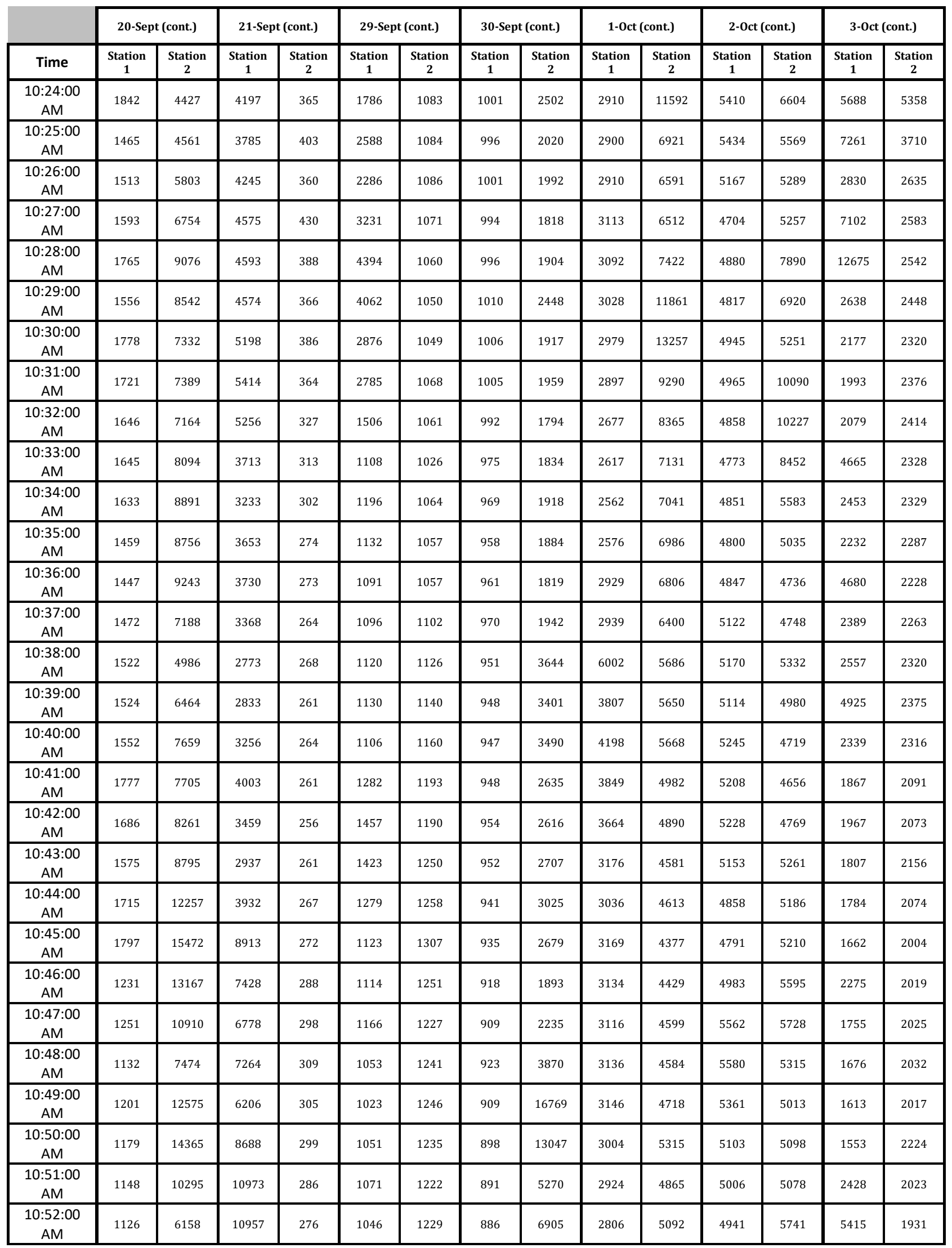




\begin{tabular}{|c|c|c|c|c|c|c|c|c|c|c|c|c|c|c|}
\hline \multirow[b]{2}{*}{ Time } & \multicolumn{2}{|c|}{ 20-Sept (cont.) } & \multicolumn{2}{|c|}{ 21-Sept (cont.) } & \multicolumn{2}{|c|}{ 29-Sept (cont.) } & \multicolumn{2}{|c|}{ 30-Sept (cont.) } & \multicolumn{2}{|c|}{ 1-Oct (cont.) } & \multicolumn{2}{|c|}{ 2-oct (cont.) } & \multicolumn{2}{|c|}{ 3-Oct (cont.) } \\
\hline & $\begin{array}{c}\text { Station } \\
1\end{array}$ & $\begin{array}{l}\text { Station } \\
2\end{array}$ & $\begin{array}{c}\text { Station } \\
1\end{array}$ & $\begin{array}{l}\text { Station } \\
2\end{array}$ & $\begin{array}{c}\text { Station } \\
1\end{array}$ & $\begin{array}{l}\text { Station } \\
\quad 2\end{array}$ & $\begin{array}{c}\text { Station } \\
1\end{array}$ & $\begin{array}{c}\text { Station } \\
2\end{array}$ & $\begin{array}{c}\text { Station } \\
1\end{array}$ & $\begin{array}{l}\text { Station } \\
2\end{array}$ & $\begin{array}{c}\text { Station } \\
1\end{array}$ & $\begin{array}{l}\text { Station } \\
2\end{array}$ & $\begin{array}{c}\text { Station } \\
1\end{array}$ & $\begin{array}{l}\text { Station } \\
2\end{array}$ \\
\hline $\begin{array}{c}\text { 10:53:00 } \\
\text { AM }\end{array}$ & 1145 & 3622 & 11525 & 268 & 1072 & 1206 & 873 & 4648 & 2671 & 4306 & 4784 & 5575 & 2640 & 1933 \\
\hline $\begin{array}{c}10: 54: 00 \\
\text { AM }\end{array}$ & 1182 & 3198 & 11391 & 2339 & 1592 & 1151 & 883 & 11687 & 2601 & 4132 & 5023 & 5616 & 1584 & 1925 \\
\hline $\begin{array}{c}10: 55: 00 \\
\text { AM }\end{array}$ & 1248 & 4777 & 8828 & 4915 & 1616 & 1139 & 874 & 3484 & 2492 & 4309 & 5067 & 5973 & 1895 & 1915 \\
\hline $\begin{array}{c}10: 56: 00 \\
\text { AM }\end{array}$ & 1237 & 7871 & 8053 & 4956 & 1157 & 1139 & 898 & 2938 & 2362 & 7184 & 5021 & 5321 & 6023 & 1911 \\
\hline $\begin{array}{c}10: 57: 00 \\
\text { AM }\end{array}$ & 1178 & 6548 & 10549 & 4509 & 1198 & 1145 & 885 & 3649 & 2336 & 6956 & 4902 & 5659 & 3044 & 4699 \\
\hline $\begin{array}{c}10: 58: 00 \\
\text { AM }\end{array}$ & 1088 & 6466 & 8755 & 3938 & 1066 & 1114 & 839 & 2766 & 2200 & 7507 & 4844 & 6100 & 1790 & 4280 \\
\hline $\begin{array}{c}\text { 10:59:00 } \\
\text { AM }\end{array}$ & 1025 & 12880 & 10697 & 3622 & 1188 & 1060 & 833 & 1970 & 2115 & 8610 & 4863 & 5266 & 1567 & 2233 \\
\hline $\begin{array}{c}\text { 11:00:00 } \\
\text { AM }\end{array}$ & 1024 & 6279 & 17897 & 3305 & 1249 & 1060 & 838 & 1831 & 2108 & 10088 & 4759 & 4907 & 1787 & 6304 \\
\hline $\begin{array}{c}11: 01: 00 \\
\text { AM }\end{array}$ & 983 & 6750 & 16506 & 3230 & 1203 & 1075 & 817 & 1811 & 2016 & 9438 & 4602 & 4826 & 1919 & 2244 \\
\hline $\begin{array}{c}11: 02: 00 \\
\text { AM }\end{array}$ & 917 & 5591 & 6794 & 3135 & 4516 & 1090 & 815 & 1798 & 2000 & 8891 & 4624 & 4833 & 1892 & 2370 \\
\hline $\begin{array}{c}\text { 11:03:00 } \\
\text { AM }\end{array}$ & 467 & 11390 & 5721 & 3212 & 13095 & 1103 & 809 & 1852 & 1916 & 8347 & 4654 & 4812 & 1889 & 2142 \\
\hline $\begin{array}{c}11: 04: 00 \\
\text { AM }\end{array}$ & 373 & 18331 & 5961 & 3578 & 6054 & 1163 & 808 & 1808 & 1901 & 7867 & 4622 & 4941 & 1778 & 2096 \\
\hline $\begin{array}{c}11: 05: 00 \\
\text { AM }\end{array}$ & 325 & 10283 & 7557 & 4411 & 3182 & 1167 & 812 & 1740 & 1822 & 7350 & 4843 & 4736 & 1715 & 2176 \\
\hline $\begin{array}{c}\text { 11:06:00 } \\
\text { AM }\end{array}$ & 341 & 3287 & 4815 & 3886 & 1345 & 1154 & 801 & 1755 & 1842 & 7504 & 5533 & 4624 & 1493 & 1991 \\
\hline $\begin{array}{c}11: 07: 00 \\
\text { AM }\end{array}$ & 336 & 2899 & 2054 & 3569 & 2128 & 1145 & 798 & 1733 & 1799 & 3807 & 5452 & 6132 & 1449 & 1943 \\
\hline $\begin{array}{c}11: 08: 00 \\
\text { AM }\end{array}$ & 374 & 3001 & 1907 & 3370 & 1394 & 1174 & 792 & 1814 & 1956 & 3130 & 5152 & 10124 & 1480 & 1973 \\
\hline $\begin{array}{c}\text { 11:09:00 } \\
\text { AM }\end{array}$ & 425 & 2641 & 1810 & 3298 & 10316 & 1173 & 784 & 1999 & 1980 & 3836 & 4653 & 6249 & 1478 & 2012 \\
\hline $\begin{array}{c}11: 10: 00 \\
\text { AM }\end{array}$ & 507 & 2465 & 1696 & 2617 & 10861 & 1146 & 784 & 1763 & 1668 & 3395 & 4133 & 5181 & 1453 & 1984 \\
\hline $\begin{array}{c}\text { 11:11:00 } \\
\text { AM }\end{array}$ & 551 & 2442 & 1647 & 2357 & 1312 & 1188 & 791 & 1806 & 1624 & 3515 & 4034 & 4814 & 1513 & 1967 \\
\hline $\begin{array}{c}11: 12: 00 \\
\text { AM }\end{array}$ & 529 & 2433 & 1654 & 1989 & 1322 & 1216 & 788 & 1772 & 1683 & 4832 & 4093 & 4436 & 1538 & 1941 \\
\hline $\begin{array}{c}\text { 11:13:00 } \\
\text { AM }\end{array}$ & 543 & 2438 & 1579 & 1969 & 1200 & 1201 & 777 & 1792 & 1596 & 3787 & 4132 & 4563 & 1535 & 1953 \\
\hline $\begin{array}{c}\text { 11:14:00 } \\
\text { AM }\end{array}$ & 548 & 2393 & 1682 & 1879 & 1203 & 1233 & 786 & 1866 & 1555 & 2940 & 4496 & 5365 & 1479 & 1963 \\
\hline $\begin{array}{c}\text { 11:15:00 } \\
\text { AM }\end{array}$ & 532 & 2388 & 2293 & 1794 & 1098 & 1209 & 765 & 1802 & 1595 & 2896 & 4316 & 4521 & 1524 & 2130 \\
\hline $\begin{array}{c}\text { 11:16:00 } \\
\text { AM }\end{array}$ & 508 & 2392 & 2109 & 1590 & 1154 & 1211 & 756 & 1821 & 1579 & 3421 & 4061 & 4546 & 1510 & 2542 \\
\hline $\begin{array}{c}\text { 11:17:00 } \\
\text { AM }\end{array}$ & 388 & 2420 & 2107 & 1556 & 1190 & 1204 & 749 & 1885 & 1611 & 3980 & 4309 & 4576 & 1502 & 2694 \\
\hline $\begin{array}{c}11: 18: 00 \\
\text { AM }\end{array}$ & 401 & 2402 & 2099 & 1465 & 1140 & 1203 & 739 & 2020 & 1577 & 2930 & 5371 & 5541 & 1500 & 3140 \\
\hline $\begin{array}{c}\text { 11:19:00 } \\
\text { AM }\end{array}$ & 414 & 2403 & 2033 & 1332 & 1165 & 1188 & 735 & 1896 & 1550 & 2626 & 5112 & 4956 & 1492 & 2315 \\
\hline $\begin{array}{c}11: 20: 00 \\
\text { AM }\end{array}$ & 427 & 2393 & 1969 & 1139 & 1161 & 1191 & 730 & 2014 & 1546 & 2426 & 4832 & 5309 & 1471 & 2064 \\
\hline $\begin{array}{c}11: 21: 00 \\
\text { AM }\end{array}$ & 487 & 2388 & 1991 & 1059 & 1127 & 1191 & 723 & 1829 & 1566 & 2356 & 4719 & 4654 & 1509 & 2046 \\
\hline
\end{tabular}




\begin{tabular}{|c|c|c|c|c|c|c|c|c|c|c|c|c|c|c|}
\hline \multirow[b]{2}{*}{ Time } & \multicolumn{2}{|c|}{ 20-Sept (cont.) } & \multicolumn{2}{|c|}{ 21-Sept (cont.) } & \multicolumn{2}{|c|}{ 29-Sept (cont.) } & \multicolumn{2}{|c|}{ 30-Sept (cont.) } & \multicolumn{2}{|c|}{ 1-Oct (cont.) } & \multicolumn{2}{|c|}{ 2-oct (cont.) } & \multicolumn{2}{|c|}{ 3-Oct (cont.) } \\
\hline & $\begin{array}{c}\text { Station } \\
1\end{array}$ & $\begin{array}{l}\text { Station } \\
2\end{array}$ & $\begin{array}{c}\text { Station } \\
1\end{array}$ & $\begin{array}{c}\text { Station } \\
2\end{array}$ & $\begin{array}{c}\text { Station } \\
1\end{array}$ & $\begin{array}{l}\text { Station } \\
2\end{array}$ & $\begin{array}{c}\text { Station } \\
1\end{array}$ & $\begin{array}{l}\text { Station } \\
2\end{array}$ & $\begin{array}{c}\text { Station } \\
1\end{array}$ & $\begin{array}{l}\text { Station } \\
2\end{array}$ & $\begin{array}{c}\text { Station } \\
1\end{array}$ & $\begin{array}{c}\text { Station } \\
2\end{array}$ & $\begin{array}{c}\text { Station } \\
1\end{array}$ & $\begin{array}{c}\text { Station } \\
2\end{array}$ \\
\hline $\begin{array}{c}11: 22: 00 \\
\text { AM }\end{array}$ & 466 & 2292 & 1901 & 997 & 1070 & 1164 & 719 & 1706 & 1537 & 2249 & 4558 & 4372 & 2656 & 2065 \\
\hline $\begin{array}{c}11: 23: 00 \\
\text { AM }\end{array}$ & 448 & 2224 & 1883 & 888 & 1111 & 1149 & 707 & 1707 & 1603 & 2271 & 4419 & 4223 & 5436 & 2042 \\
\hline $\begin{array}{c}11: 24: 00 \\
\text { AM }\end{array}$ & 450 & 2295 & 1962 & 807 & 1119 & 1132 & 703 & 1899 & 1555 & 2262 & 4682 & 4257 & 3547 & 2036 \\
\hline $\begin{array}{c}11: 25: 00 \\
\text { AM }\end{array}$ & 458 & 2330 & 1932 & 694 & 1075 & 1107 & 705 & 2199 & 1547 & 2320 & 5787 & 6005 & 1993 & 2044 \\
\hline $\begin{array}{c}11: 26: 00 \\
\text { AM }\end{array}$ & 458 & 2329 & 1717 & 631 & 1052 & 1119 & 711 & 1951 & 1497 & 2385 & 4129 & 11577 & 1993 & 2133 \\
\hline $\begin{array}{c}11: 27: 00 \\
\text { AM }\end{array}$ & 461 & 2359 & 1471 & 567 & 2417 & 1115 & 703 & 1762 & 1448 & 2531 & 4195 & 7669 & 2010 & 2120 \\
\hline $\begin{array}{c}11: 28: 00 \\
\text { AM }\end{array}$ & 456 & 2340 & 1488 & 510 & 1021 & 1103 & 707 & 1705 & 1387 & 2611 & 4269 & 6689 & 1736 & 2023 \\
\hline $\begin{array}{c}\text { 11:29:00 } \\
\text { AM }\end{array}$ & 455 & 2372 & 1442 & 454 & 1037 & 1105 & 694 & 1753 & 1366 & 2667 & 4069 & 5517 & 1621 & 2018 \\
\hline $\begin{array}{c}11: 30: 00 \\
\text { AM }\end{array}$ & 480 & 3166 & 1395 & 389 & 1093 & 1117 & 698 & 1673 & 1359 & 2649 & 4030 & 5298 & 1588 & 2015 \\
\hline $\begin{array}{c}11: 31: 00 \\
\text { AM }\end{array}$ & 474 & 3103 & 1268 & 584 & 1027 & 1105 & 686 & 1762 & 1347 & 2700 & 4089 & 4335 & 1562 & 2027 \\
\hline $\begin{array}{c}11: 32: 00 \\
\text { AM }\end{array}$ & 485 & 4588 & 1249 & 190 & 978 & 1098 & 676 & 1710 & 1311 & 2875 & 4244 & 4103 & 1569 & 2035 \\
\hline $\begin{array}{c}\text { 11:33:00 } \\
\text { AM }\end{array}$ & 485 & 6628 & 1269 & 220 & 1013 & 1098 & 676 & 1678 & 1299 & 2759 & 4579 & 4395 & 2022 & 2006 \\
\hline $\begin{array}{c}11: 34: 00 \\
\text { AM }\end{array}$ & 483 & 7250 & 1536 & 162 & 1023 & 1086 & 668 & 1699 & 1297 & 2621 & 4590 & 5257 & 1819 & 2004 \\
\hline $\begin{array}{c}11: 35: 00 \\
\text { AM }\end{array}$ & 477 & 6086 & 1820 & 294 & 1043 & 1077 & 662 & 1836 & 1290 & 2681 & 5576 & 4820 & 1642 & 2094 \\
\hline $\begin{array}{c}11: 36: 00 \\
\text { AM }\end{array}$ & 1234 & 4353 & 1787 & 646 & 1187 & 1064 & 646 & 2108 & 1318 & 2524 & 5195 & 4987 & 1584 & 1710 \\
\hline $\begin{array}{c}11: 37: 00 \\
\text { AM }\end{array}$ & 1845 & 3463 & 1798 & 568 & 1242 & 5015 & 640 & 1970 & 1314 & 2470 & 5097 & 4925 & 1568 & 1685 \\
\hline $\begin{array}{c}\text { 11:38:00 } \\
\text { AM }\end{array}$ & 6363 & 3235 & 1766 & 1 & 1259 & 19527 & 652 & 2711 & 1281 & 3841 & 6431 & 5125 & 1538 & 1688 \\
\hline $\begin{array}{c}11: 39: 00 \\
\text { AM }\end{array}$ & 3103 & 3162 & 1687 & 0 & 1180 & 2276 & 639 & 2045 & 1268 & 3808 & 5887 & 5471 & 1514 & 1708 \\
\hline $\begin{array}{c}11: 40: 00 \\
\text { AM }\end{array}$ & 1967 & 2708 & 1649 & 430 & 1187 & 1072 & 637 & 1997 & 1262 & 4245 & 5872 & 5459 & 1536 & 1660 \\
\hline $\begin{array}{c}\text { 11:41:00 } \\
\text { AM }\end{array}$ & 1704 & 2462 & 1650 & 523 & 1327 & 1077 & 631 & 2246 & 1298 & 3011 & 5646 & 5581 & 1626 & 1544 \\
\hline $\begin{array}{c}11: 42: 00 \\
\text { AM }\end{array}$ & 1647 & 2521 & 1660 & 553 & 1299 & 1143 & 620 & 1990 & 1354 & 2270 & 5184 & 5758 & 1564 & 1513 \\
\hline $\begin{array}{c}\text { 11:43:00 } \\
\text { AM }\end{array}$ & 1632 & 2472 & 1675 & 541 & 1107 & 1149 & 618 & 1761 & 1373 & 2218 & 5127 & 5837 & 3229 & 1461 \\
\hline $\begin{array}{c}11: 44: 00 \\
\text { AM }\end{array}$ & 1634 & 2301 & 1691 & 547 & 1179 & 1203 & 614 & 1928 & 1352 & 2205 & 4618 & 6066 & 3445 & 1463 \\
\hline $\begin{array}{c}\text { 11:45:00 } \\
\text { AM }\end{array}$ & 1650 & 2373 & 1655 & 576 & 1201 & 1201 & 604 & 2049 & 1364 & 2218 & 7001 & 5409 & 6510 & 1814 \\
\hline $\begin{array}{c}\text { 11:46:00 } \\
\text { AM }\end{array}$ & 1640 & 2429 & 1699 & 588 & 1069 & 1186 & 606 & 1739 & 1345 & 2239 & 7876 & 5549 & 4492 & 2125 \\
\hline $\begin{array}{c}11: 47: 00 \\
\text { AM }\end{array}$ & 1646 & 3216 & 1644 & 607 & 1168 & 1153 & 600 & 1751 & 1328 & 2326 & 7567 & 5151 & 1956 & 2103 \\
\hline $\begin{array}{c}\text { 11:48:00 } \\
\text { AM }\end{array}$ & 1613 & 7367 & 1635 & 629 & 994 & 1114 & 587 & 1711 & 1315 & 2311 & 8292 & 4629 & 1558 & 2073 \\
\hline $\begin{array}{c}11: 49: 00 \\
\text { AM }\end{array}$ & 1454 & 6473 & 1644 & 649 & 1170 & 1107 & 582 & 1689 & 1315 & 2545 & 6994 & 5551 & 1525 & 2049 \\
\hline $\begin{array}{c}11: 50: 00 \\
\text { AM }\end{array}$ & 1201 & 4998 & 1633 & 659 & 1179 & 1102 & 583 & 1601 & 1303 & 2544 & 5165 & 6517 & 1490 & 2060 \\
\hline
\end{tabular}




\begin{tabular}{|c|c|c|c|c|c|c|c|c|c|c|c|c|c|c|}
\hline \multirow[b]{2}{*}{ Time } & \multicolumn{2}{|c|}{ 20-Sept (cont.) } & \multicolumn{2}{|c|}{ 21-Sept (cont.) } & \multicolumn{2}{|c|}{ 29-Sept (cont.) } & \multicolumn{2}{|c|}{ 30-Sept (cont.) } & \multicolumn{2}{|c|}{ 1-Oct (cont.) } & \multicolumn{2}{|c|}{ 2-oct (cont.) } & \multicolumn{2}{|c|}{ 3-Oct (cont.) } \\
\hline & $\begin{array}{c}\text { Station } \\
1\end{array}$ & $\begin{array}{c}\text { Station } \\
2\end{array}$ & $\begin{array}{c}\text { Station } \\
1\end{array}$ & $\begin{array}{l}\text { Station } \\
2\end{array}$ & $\begin{array}{c}\text { Station } \\
1\end{array}$ & $\begin{array}{l}\text { Station } \\
2\end{array}$ & $\begin{array}{c}\text { Station } \\
1\end{array}$ & $\begin{array}{l}\text { Station } \\
2\end{array}$ & $\begin{array}{c}\text { Station } \\
1\end{array}$ & $\begin{array}{l}\text { Station } \\
2\end{array}$ & $\begin{array}{c}\text { Station } \\
1\end{array}$ & $\begin{array}{c}\text { Station } \\
2\end{array}$ & $\begin{array}{c}\text { Station } \\
1\end{array}$ & $\begin{array}{c}\text { Station } \\
2\end{array}$ \\
\hline $\begin{array}{c}11: 51: 00 \\
\text { AM }\end{array}$ & 876 & 7354 & 1599 & 676 & 5268 & 1095 & 562 & 1595 & 1243 & 2696 & 4118 & 7415 & 1515 & 2050 \\
\hline $\begin{array}{c}11: 52: 00 \\
\text { AM }\end{array}$ & 1508 & 7350 & 1588 & 680 & 7805 & 1103 & 556 & 1995 & 1220 & 2542 & 4956 & 7219 & 1486 & 2117 \\
\hline $\begin{array}{c}\text { 11:53:00 } \\
\text { AM }\end{array}$ & 1469 & 7422 & 1583 & 687 & 8826 & 1112 & 556 & 1852 & 1195 & 3088 & 7783 & 3649 & 1517 & 2123 \\
\hline $\begin{array}{c}11: 54: 00 \\
\text { AM }\end{array}$ & 1460 & 7925 & 1576 & 691 & 9475 & 1117 & 557 & 1680 & 1178 & 4100 & 4725 & 5393 & 1712 & 2122 \\
\hline $\begin{array}{c}11: 55: 00 \\
\text { AM }\end{array}$ & 1411 & 8774 & 1560 & 702 & 9910 & 1096 & 534 & 1655 & 1177 & 2693 & 3463 & 3563 & 6022 & 2116 \\
\hline $\begin{array}{c}11: 56: 00 \\
\text { AM }\end{array}$ & 1357 & 9582 & 1522 & 708 & 9586 & 1086 & 531 & 1612 & 1185 & 1928 & 4472 & 3520 & 1879 & 2134 \\
\hline $\begin{array}{c}11: 57: 00 \\
\text { AM }\end{array}$ & 1368 & 10094 & 1516 & 711 & 9610 & 1091 & 528 & 1617 & 1171 & 2038 & 5327 & 3821 & 1487 & 2122 \\
\hline $\begin{array}{c}\text { 11:58:00 } \\
\text { AM }\end{array}$ & 1374 & 10616 & 1501 & 705 & 9097 & 1127 & 525 & 1705 & 1184 & 2167 & 4022 & 3884 & 1679 & 2124 \\
\hline $\begin{array}{c}11: 59: 00 \\
\text { AM }\end{array}$ & 1371 & 6957 & 1510 & 465 & 6434 & 1172 & 517 & 1774 & 1201 & 2058 & 2697 & 3798 & 2280 & 2130 \\
\hline $\begin{array}{c}\text { 12:00:00 } \\
\text { PM }\end{array}$ & 1377 & 1531 & 1498 & 346 & 1339 & 1197 & 506 & 1686 & 1185 & 1936 & 2993 & 3591 & 1663 & 2147 \\
\hline $\begin{array}{c}\text { 12:01:00 } \\
\text { PM }\end{array}$ & 1334 & 2041 & 2095 & 364 & 1366 & 1210 & 503 & 1663 & 1178 & 1929 & 2987 & 3561 & 2386 & 2147 \\
\hline $\begin{array}{c}12: 02: 00 \\
\text { PM }\end{array}$ & 1288 & 2381 & 1747 & 351 & 1446 & 1252 & 500 & 1692 & 1163 & 1920 & 2527 & 3071 & 1520 & 2141 \\
\hline $\begin{array}{c}\text { 12:03:00 } \\
\text { PM }\end{array}$ & 1258 & 2523 & 2116 & 343 & 1489 & 1260 & 494 & 1678 & 1162 & 2015 & 2609 & 2777 & 1479 & 2111 \\
\hline $\begin{array}{c}12: 04: 00 \\
\text { PM }\end{array}$ & 1042 & 3248 & 2397 & 339 & 1614 & 1286 & 487 & 1707 & 1149 & 1948 & 2465 & 3229 & 1469 & 2097 \\
\hline $\begin{array}{c}\text { 12:05:00 } \\
\text { PM }\end{array}$ & 778 & 3777 & 2381 & 346 & 1891 & 1312 & 480 & 1723 & 1141 & 2690 & 2387 & 3170 & 1480 & 2095 \\
\hline $\begin{array}{c}\text { 12:06:00 } \\
\text { PM }\end{array}$ & 790 & 3999 & 2332 & 353 & 1896 & 1341 & 482 & 1702 & 1144 & 2444 & 2349 & 2553 & 1840 & 2087 \\
\hline $\begin{array}{c}\text { 12:07:00 } \\
\text { PM }\end{array}$ & 1322 & 2908 & 2311 & 354 & 2118 & 1364 & 476 & 1713 & 1131 & 2136 & 2305 & 2420 & 1575 & 2063 \\
\hline $\begin{array}{c}\text { 12:08:00 } \\
\text { PM }\end{array}$ & 1266 & 3296 & 2313 & 355 & 2229 & 1343 & 477 & 1699 & 1123 & 1970 & 2375 & 2365 & 1473 & 2027 \\
\hline $\begin{array}{c}\text { 12:09:00 } \\
\text { PM }\end{array}$ & 1250 & 4317 & 2267 & 361 & 2051 & 1323 & 470 & 1698 & 1102 & 2009 & 2373 & 2319 & 1481 & 2000 \\
\hline $\begin{array}{c}\text { 12:10:00 } \\
\text { PM }\end{array}$ & 1149 & 6643 & 2238 & 363 & 2305 & 1317 & 452 & 1674 & 1100 & 2066 & 2263 & 2328 & 1530 & 1972 \\
\hline $\begin{array}{c}\text { 12:11:00 } \\
\text { PM }\end{array}$ & 1145 & 5301 & 2245 & 366 & 2291 & 1349 & 455 & 1674 & 1102 & 2077 & 2269 & 2396 & 1558 & 1915 \\
\hline $\begin{array}{c}\text { 12:12:00 } \\
\text { PM }\end{array}$ & 1206 & 5388 & 2266 & 376 & 1932 & 1374 & 434 & 1742 & 1096 & 4488 & 2228 & 2342 & 1961 & 1862 \\
\hline $\begin{array}{c}\text { 12:13:00 } \\
\text { PM }\end{array}$ & 1189 & 4465 & 2284 & 378 & 1808 & 1381 & 3437 & 1780 & 1091 & 6156 & 2153 & 2298 & 1830 & 1833 \\
\hline $\begin{array}{c}\text { 12:14:00 } \\
\text { PM }\end{array}$ & 1174 & 4190 & 2286 & 383 & 1794 & 1386 & 3166 & 1616 & 1085 & 2524 & 2178 & 2254 & 2910 & 1801 \\
\hline $\begin{array}{c}\text { 12:15:00 } \\
\text { PM }\end{array}$ & 1115 & 4106 & 2244 & 386 & 1779 & 1372 & 1498 & 1583 & 1080 & 6896 & 2122 & 2238 & 1564 & 1830 \\
\hline $\begin{array}{c}\text { 12:16:00 } \\
\text { PM }\end{array}$ & 1077 & 4570 & 2227 & 383 & 1854 & 1403 & 64 & 1530 & 1082 & 7453 & 2113 & 4380 & 1445 & 1828 \\
\hline $\begin{array}{c}\text { 12:17:00 } \\
\text { PM }\end{array}$ & 869 & 6633 & 2250 & 386 & 1876 & 1382 & 705 & 1473 & 1078 & 19252 & 3601 & 8524 & 1422 & 1867 \\
\hline $\begin{array}{c}\text { 12:18:00 } \\
\text { PM }\end{array}$ & 620 & 7342 & 2257 & 398 & 1796 & 1373 & 903 & 1445 & 1068 & 13540 & 3835 & 6661 & 1436 & 1905 \\
\hline $\begin{array}{c}\text { 12:19:00 } \\
\text { PM }\end{array}$ & 436 & 4953 & 2331 & 396 & 10248 & 1356 & 904 & 1388 & 1057 & 10845 & 2108 & 2846 & 1439 & 1928 \\
\hline
\end{tabular}




\begin{tabular}{|c|c|c|c|c|c|c|c|c|c|c|c|c|c|c|}
\hline \multirow[b]{2}{*}{ Time } & \multicolumn{2}{|c|}{ 20-Sept (cont.) } & \multicolumn{2}{|c|}{ 21-Sept (cont.) } & \multicolumn{2}{|c|}{ 29-Sept (cont.) } & \multicolumn{2}{|c|}{ 30-Sept (cont.) } & \multicolumn{2}{|c|}{ 1-Oct (cont.) } & \multicolumn{2}{|c|}{ 2-oct (cont.) } & \multicolumn{2}{|c|}{ 3-Oct (cont.) } \\
\hline & $\begin{array}{c}\text { Station } \\
1\end{array}$ & $\begin{array}{l}\text { Station } \\
2\end{array}$ & $\begin{array}{c}\text { Station } \\
1\end{array}$ & $\begin{array}{c}\text { Station } \\
2\end{array}$ & $\begin{array}{c}\text { Station } \\
1\end{array}$ & $\begin{array}{l}\text { Station } \\
2\end{array}$ & $\begin{array}{c}\text { Station } \\
1\end{array}$ & $\begin{array}{l}\text { Station } \\
2\end{array}$ & $\begin{array}{c}\text { Station } \\
1\end{array}$ & $\begin{array}{l}\text { Station } \\
2\end{array}$ & $\begin{array}{c}\text { Station } \\
1\end{array}$ & $\begin{array}{c}\text { Station } \\
2\end{array}$ & $\begin{array}{c}\text { Station } \\
1\end{array}$ & $\begin{array}{c}\text { Station } \\
2\end{array}$ \\
\hline $\begin{array}{c}12: 20: 00 \\
\text { PM }\end{array}$ & 471 & 3693 & 2339 & 401 & 6605 & 1315 & 905 & 1348 & 1047 & 12280 & 2797 & 3059 & 1437 & 1960 \\
\hline $\begin{array}{c}12: 21: 00 \\
\text { PM }\end{array}$ & 429 & 6917 & 2307 & 416 & 1749 & 1315 & 907 & 1351 & 1046 & 12643 & 3903 & 4157 & 1439 & 1967 \\
\hline $\begin{array}{c}\text { 12:22:00 } \\
\text { PM }\end{array}$ & 1107 & 4811 & 2254 & 423 & 1891 & 1318 & 908 & 1331 & 1044 & 8949 & 3764 & 3261 & 1453 & 1989 \\
\hline $\begin{array}{c}12: 23: 00 \\
\text { PM }\end{array}$ & 1062 & 5423 & 2162 & 421 & 1808 & 1305 & 924 & 1502 & 1039 & 6990 & 3631 & 4513 & 1473 & 2002 \\
\hline $\begin{array}{c}\text { 12:24:00 } \\
\text { PM }\end{array}$ & 1005 & 6140 & 2376 & 425 & 1793 & 1304 & 930 & 1490 & 1033 & 4999 & 3163 & 4521 & 2024 & 2027 \\
\hline $\begin{array}{c}12: 25: 00 \\
\text { PM }\end{array}$ & 1080 & 3090 & 2449 & 421 & 1750 & 1314 & 926 & 1343 & 1035 & 2796 & 3487 & 3092 & 2072 & 2020 \\
\hline $\begin{array}{c}\text { 12:26:00 } \\
\text { PM }\end{array}$ & 1061 & 2658 & 2486 & 404 & 1745 & 1310 & 912 & 1367 & 1041 & 1867 & 3397 & 2698 & 1680 & 1999 \\
\hline $\begin{array}{c}\text { 12:27:00 } \\
\text { PM }\end{array}$ & 1002 & 2547 & 2587 & 388 & 10234 & 1302 & 914 & 1408 & 1041 & 1836 & 2376 & 2683 & 1732 & 2002 \\
\hline $\begin{array}{c}12: 28: 00 \\
\text { PM }\end{array}$ & 1141 & 2759 & 2781 & 414 & 7069 & 1287 & 910 & 1483 & 1030 & 1839 & 2378 & 2854 & 1473 & 1991 \\
\hline $\begin{array}{c}\text { 12:29:00 } \\
\text { PM }\end{array}$ & 1124 & 2296 & 2734 & 447 & 2046 & 1309 & 894 & 1454 & 1039 & 1868 & 2532 & 3954 & 1459 & 2018 \\
\hline $\begin{array}{c}12: 30: 00 \\
\text { PM }\end{array}$ & 1115 & 2135 & 2617 & 460 & 1646 & 1288 & 743 & 1403 & 1018 & 1903 & 3077 & 4371 & 1638 & 1959 \\
\hline $\begin{array}{c}\text { 12:31:00 } \\
\text { PM }\end{array}$ & 1094 & 1919 & 2608 & 459 & 1689 & 1277 & 506 & 1383 & 1020 & 1962 & 3311 & 3903 & 1680 & 1996 \\
\hline $\begin{array}{c}\text { 12:32:00 } \\
\text { PM }\end{array}$ & 986 & 1930 & 2692 & 463 & 1759 & 1285 & 346 & 1376 & 1021 & 1805 & 3258 & 2382 & 2169 & 2096 \\
\hline $\begin{array}{c}\text { 12:33:00 } \\
\text { PM }\end{array}$ & 812 & 2256 & 2877 & 473 & 1705 & 1271 & 303 & 1388 & 1026 & 1798 & 2881 & 1339 & 1915 & 1908 \\
\hline $\begin{array}{c}12: 34: 00 \\
\text { PM }\end{array}$ & 553 & 2230 & 3020 & 463 & 2180 & 1270 & 292 & 1414 & 1026 & 1751 & 2473 & 2117 & 1838 & 2003 \\
\hline $\begin{array}{c}12: 35: 00 \\
\text { PM }\end{array}$ & 674 & 2346 & 2577 & 469 & 1955 & 1272 & 286 & 1415 & 1030 & 1729 & 3160 & 2245 & 1922 & 2112 \\
\hline $\begin{array}{c}\text { 12:36:00 } \\
\text { PM }\end{array}$ & 1041 & 1803 & 2470 & 469 & 2441 & 1277 & 278 & 1416 & 1026 & 1805 & 5409 & 2071 & 1945 & 2373 \\
\hline $\begin{array}{c}\text { 12:37:00 } \\
\text { PM }\end{array}$ & 903 & 1747 & 2373 & 477 & 1881 & 1271 & 276 & 1422 & 1025 & 1818 & 3080 & 5503 & 1951 & 2915 \\
\hline $\begin{array}{c}\text { 12:38:00 } \\
\text { PM }\end{array}$ & 910 & 1652 & 2770 & 481 & 1739 & 1283 & 272 & 1404 & 1014 & 2067 & 3134 & 6315 & 1849 & 3480 \\
\hline $\begin{array}{c}\text { 12:39:00 } \\
\text { PM }\end{array}$ & 879 & 1588 & 2871 & 486 & 1725 & 1269 & 270 & 1401 & 1014 & 1851 & 2601 & 2395 & 1949 & 3029 \\
\hline $\begin{array}{c}\text { 12:40:00 } \\
\text { PM }\end{array}$ & 849 & 1435 & 3232 & 490 & 9543 & 1286 & 268 & 1441 & 1010 & 1752 & 2386 & 3316 & 2388 & 3817 \\
\hline $\begin{array}{c}\text { 12:41:00 } \\
\text { PM }\end{array}$ & 854 & 1430 & 3136 & 487 & 2465 & 1279 & 275 & 1476 & 1006 & 1727 & 2553 & 3765 & 2511 & 2119 \\
\hline $\begin{array}{c}\text { 12:42:00 } \\
\text { PM }\end{array}$ & 883 & 1414 & 3182 & 487 & 3616 & 1299 & 269 & 1390 & 997 & 1710 & 2514 & 3627 & 2020 & 2188 \\
\hline $\begin{array}{c}\text { 12:43:00 } \\
\text { PM }\end{array}$ & 885 & 1326 & 3202 & 504 & 5145 & 1285 & 265 & 1456 & 989 & 1708 & 2753 & 7945 & 1693 & 2903 \\
\hline $\begin{array}{c}\text { 12:44:00 } \\
\text { PM }\end{array}$ & 896 & 1240 & 3449 & 505 & 4550 & 1283 & 260 & 1511 & 988 & 1703 & 2624 & 7366 & 1588 & 3047 \\
\hline $\begin{array}{c}12: 45: 00 \\
\text { PM }\end{array}$ & 817 & 1156 & 3461 & 509 & 2759 & 1284 & 262 & 1559 & 985 & 1715 & 2501 & 4671 & 1631 & 20282 \\
\hline $\begin{array}{c}\text { 12:46:00 } \\
\text { PM }\end{array}$ & 648 & 1132 & 3555 & 514 & 2413 & 1285 & 260 & 1587 & 982 & 1991 & 2436 & 4211 & 1639 & 10844 \\
\hline $\begin{array}{c}12: 47: 00 \\
\text { PM }\end{array}$ & 468 & 1128 & 3796 & 516 & 2244 & 1290 & 256 & 1627 & 985 & 1726 & 2580 & 4306 & 1694 & 4057 \\
\hline $\begin{array}{c}12: 48: 00 \\
\text { PM }\end{array}$ & 306 & 1157 & 6899 & 511 & 1976 & 1292 & 259 & 1594 & 978 & 1704 & 2600 & 3676 & 1797 & 2987 \\
\hline
\end{tabular}




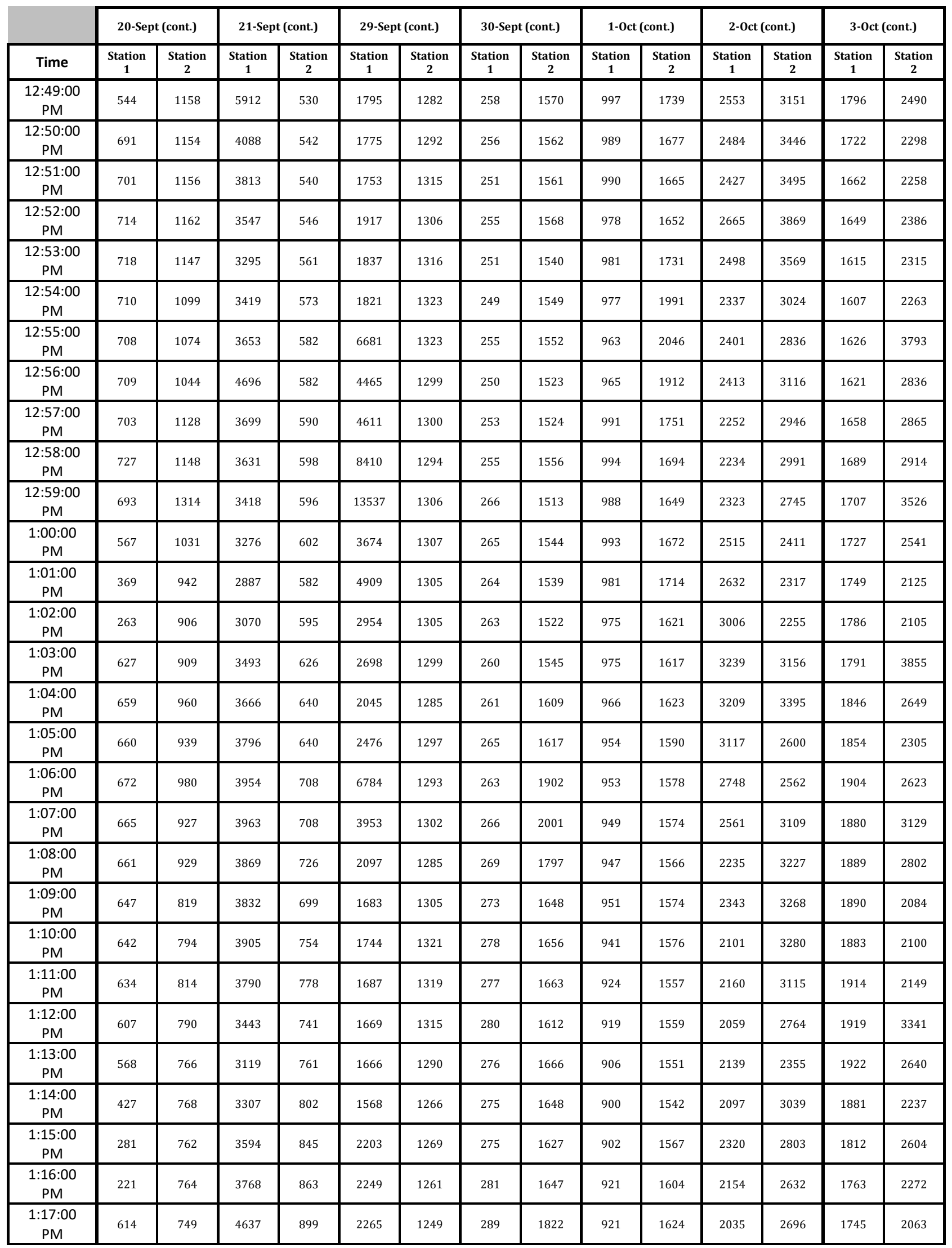




\begin{tabular}{|c|c|c|c|c|c|c|c|c|c|c|c|c|c|c|}
\hline \multirow[b]{2}{*}{ Time } & \multicolumn{2}{|c|}{ 20-Sept (cont.) } & \multicolumn{2}{|c|}{ 21-Sept (cont.) } & \multicolumn{2}{|c|}{ 29-Sept (cont.) } & \multicolumn{2}{|c|}{ 30-Sept (cont.) } & \multicolumn{2}{|c|}{ 1-Oct (cont.) } & \multicolumn{2}{|c|}{ 2-Oct (cont.) } & \multicolumn{2}{|c|}{ 3-Oct (cont.) } \\
\hline & $\begin{array}{c}\text { Station } \\
1\end{array}$ & $\begin{array}{c}\text { Station } \\
2\end{array}$ & $\begin{array}{c}\text { Station } \\
1\end{array}$ & $\begin{array}{c}\text { Station } \\
2\end{array}$ & $\begin{array}{c}\text { Station } \\
1\end{array}$ & $\begin{array}{c}\text { Station } \\
2\end{array}$ & $\begin{array}{c}\text { Station } \\
1\end{array}$ & $\begin{array}{c}\text { Station } \\
2\end{array}$ & $\begin{array}{c}\text { Station } \\
1\end{array}$ & $\begin{array}{c}\text { Station } \\
2\end{array}$ & $\begin{array}{c}\text { Station } \\
1\end{array}$ & $\begin{array}{c}\text { Station } \\
2\end{array}$ & $\begin{array}{c}\text { Station } \\
1\end{array}$ & $\begin{array}{c}\text { Station } \\
2\end{array}$ \\
\hline $\begin{array}{c}1: 19: 00 \\
\text { PM }\end{array}$ & 576 & 723 & 4064 & 860 & 6335 & 1240 & 277 & 2003 & 906 & 1618 & 1969 & 2362 & 1719 & 2164 \\
\hline $\begin{array}{c}1: 21: 00 \\
\text { PM }\end{array}$ & 573 & 713 & 4060 & 873 & 2025 & 1234 & 275 & 1848 & 896 & 1628 & 2098 & 2777 & 1994 & 2063 \\
\hline $\begin{array}{c}1: 22: 00 \\
\text { PM }\end{array}$ & 568 & 737 & 3878 & 859 & 1867 & 1243 & 267 & 1764 & 890 & 1641 & 2113 & 3190 & 1945 & 2019 \\
\hline $\begin{array}{c}1: 23: 00 \\
\text { PM }\end{array}$ & 558 & 781 & 4767 & 889 & 1873 & 1188 & 256 & 1823 & 899 & 1593 & 2009 & 2230 & 2089 & 2002 \\
\hline $\begin{array}{c}1: 25: 00 \\
\text { PM }\end{array}$ & 547 & 784 & 3248 & 936 & 1592 & 1142 & 234 & 2317 & 885 & 1566 & 2030 & 2074 & 1920 & 2097 \\
\hline $\begin{array}{c}1: 26: 00 \\
\text { PM }\end{array}$ & 534 & 723 & 4714 & 940 & 1639 & 1156 & 222 & 2304 & 887 & 1723 & 2050 & 2109 & 1674 & 2151 \\
\hline $\begin{array}{c}1: 27: 00 \\
\text { PM }\end{array}$ & 495 & 754 & 4895 & 978 & 1605 & 1145 & 213 & 1793 & 885 & 2118 & 2038 & 2294 & 1627 & 2035 \\
\hline $\begin{array}{c}1: 28: 00 \\
\text { PM }\end{array}$ & 342 & 1142 & 4855 & 931 & 1822 & 1142 & 206 & 1743 & 887 & 2945 & 2044 & 2094 & 1640 & 2239 \\
\hline $\begin{array}{c}1: 29: 00 \\
\text { PM }\end{array}$ & 235 & 1077 & 4701 & 971 & 1999 & 1140 & 205 & 1724 & 880 & 3312 & 2046 & 2315 & 1633 & 4668 \\
\hline $\begin{array}{c}1: 30: 00 \\
\text { PM }\end{array}$ & 263 & 696 & 4042 & 1004 & 1705 & 1143 & 205 & 1765 & 885 & 3471 & 1843 & 2370 & 1744 & 3136 \\
\hline $\begin{array}{c}1: 31: 00 \\
\text { PM }\end{array}$ & 569 & 775 & 4170 & 1013 & 1662 & 1158 & 206 & 1791 & 872 & 2992 & 1921 & 2108 & 1791 & 2340 \\
\hline $\begin{array}{c}1: 33: 00 \\
\text { PM }\end{array}$ & 543 & 807 & 4063 & 1022 & 6370 & 1176 & 204 & 1796 & 880 & 1804 & 1807 & 2150 & 1992 & 2009 \\
\hline $\begin{array}{c}1: 34: 00 \\
\text { PM }\end{array}$ & 549 & 702 & 4322 & 974 & 1666 & 1169 & 200 & 1904 & 875 & 1786 & 1792 & 2189 & 1787 & 1975 \\
\hline $\begin{array}{c}1: 35: 00 \\
\text { PM }\end{array}$ & 545 & 753 & 4327 & 976 & 1590 & 1169 & 206 & 2256 & 871 & 1713 & 1730 & 2162 & 1796 & 1959 \\
\hline $\begin{array}{c}1: 36: 00 \\
\text { PM }\end{array}$ & 540 & 709 & 4124 & 983 & 1649 & 1180 & 209 & 1927 & 867 & 2030 & 1696 & 1997 & 1731 & 2011 \\
\hline $\begin{array}{c}1: 37: 00 \\
\text { PM }\end{array}$ & 531 & 731 & 3576 & 1035 & 1640 & 1181 & 206 & 1824 & 873 & 2031 & 1764 & 2164 & 1793 & 2397 \\
\hline $\begin{array}{c}1: 38: 00 \\
\text { PM }\end{array}$ & 533 & 681 & 4709 & 1060 & 1723 & 1193 & 206 & 1820 & 874 & 2394 & 1754 & 2019 & 1829 & 2282 \\
\hline $\begin{array}{c}1: 39: 00 \\
\text { PM }\end{array}$ & 521 & 668 & 4929 & 1040 & 1667 & 1200 & 203 & 1800 & 869 & 2906 & 1721 & 2199 & 1834 & 1970 \\
\hline $\begin{array}{c}1: 40: 00 \\
\text { PM }\end{array}$ & 505 & 634 & 5006 & 1026 & 1591 & 1214 & 206 & 1893 & 868 & 2440 & 1738 & 2039 & 1830 & 2095 \\
\hline $\begin{array}{c}1: 41: 00 \\
\text { PM }\end{array}$ & 434 & 641 & 4760 & 984 & 1602 & 1214 & 204 & 2002 & 863 & 2122 & 1682 & 1919 & 1886 & 2175 \\
\hline $\begin{array}{c}1: 42: 00 \\
\text { PM }\end{array}$ & 282 & 644 & 4693 & 1051 & 2492 & 1193 & 201 & 1960 & 863 & 1903 & 1713 & 1792 & 1880 & 2304 \\
\hline $\begin{array}{c}1: 43: 00 \\
\text { PM }\end{array}$ & 206 & 618 & 4734 & 1039 & 2105 & 1162 & 201 & 1958 & 862 & 1897 & 1847 & 1788 & 1993 & 4601 \\
\hline $\begin{array}{c}1: 44: 00 \\
\text { PM }\end{array}$ & 462 & 635 & 4837 & 1037 & 1924 & 1159 & 204 & 1920 & 860 & 1824 & 1835 & 2059 & 2093 & 4481 \\
\hline $\begin{array}{c}1: 45: 00 \\
\text { PM }\end{array}$ & 497 & 628 & 5117 & 1009 & 1671 & 1179 & 210 & 2676 & 852 & 1763 & 1812 & 1939 & 1901 & 9287 \\
\hline $\begin{array}{c}1: 46: 00 \\
\text { PM }\end{array}$ & 515 & 613 & 4728 & 1046 & 1621 & 1203 & 213 & 2653 & 872 & 1543 & 1741 & 1834 & 1749 & 6049 \\
\hline
\end{tabular}




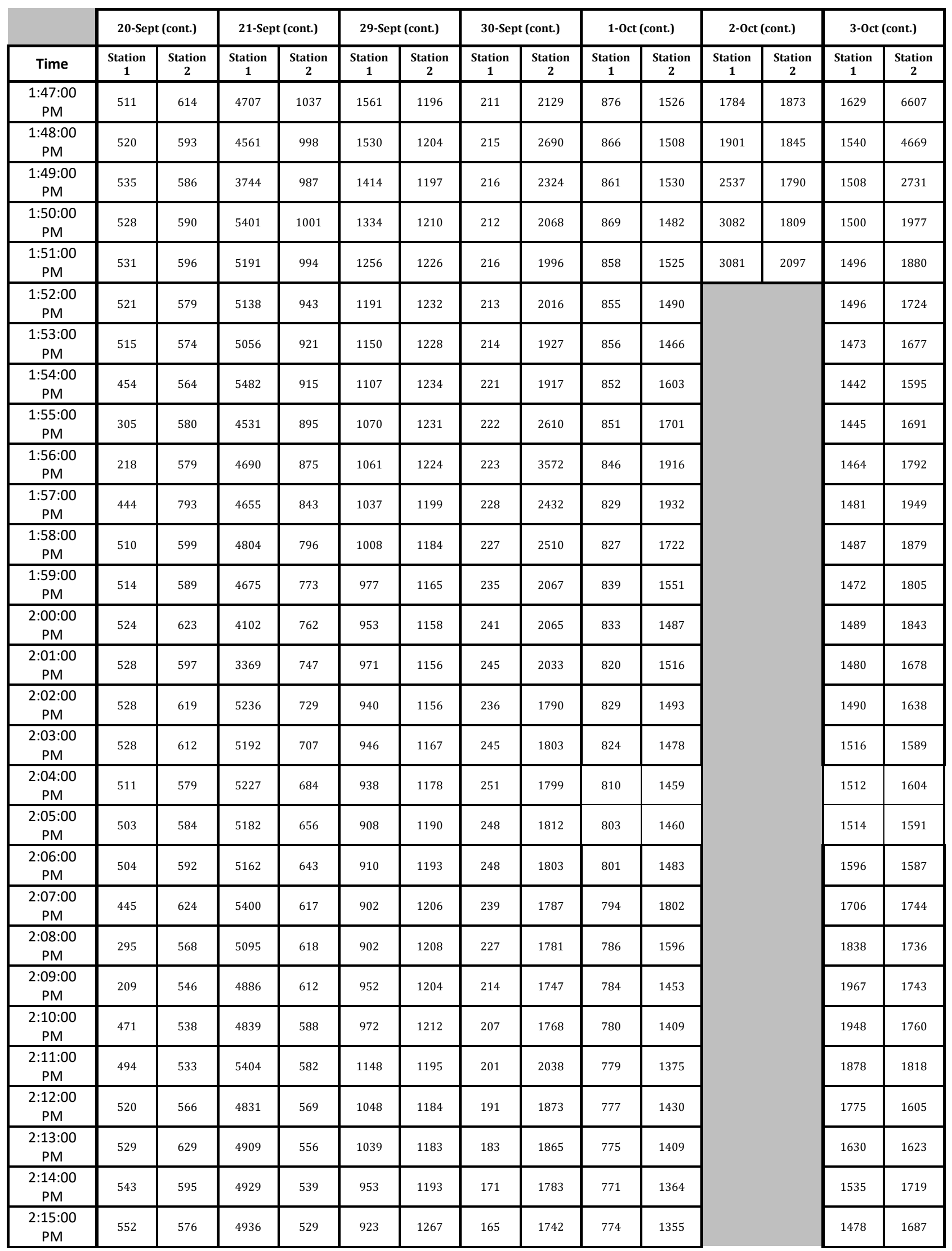




\begin{tabular}{|c|c|c|c|c|c|c|c|c|c|c|c|c|}
\hline \multirow[b]{2}{*}{ Time } & \multicolumn{2}{|c|}{ 20-Sept (cont.) } & \multicolumn{2}{|c|}{ 21-Sept (cont.) } & \multicolumn{2}{|c|}{ 29-Sept (cont.) } & \multicolumn{2}{|c|}{ 30-Sept (cont.) } & \multicolumn{2}{|c|}{ 1-Oct (cont.) } & \multicolumn{2}{|c|}{ 3-Oct (cont.) } \\
\hline & $\begin{array}{c}\text { Station } \\
1\end{array}$ & $\begin{array}{c}\text { Station } \\
2\end{array}$ & $\begin{array}{c}\text { Station } \\
1\end{array}$ & $\begin{array}{c}\text { Station } \\
2\end{array}$ & $\begin{array}{c}\text { Station } \\
1\end{array}$ & $\begin{array}{c}\text { Station } \\
2\end{array}$ & $\begin{array}{c}\text { Station } \\
1\end{array}$ & $\begin{array}{c}\text { Station } \\
2\end{array}$ & $\begin{array}{c}\text { Station } \\
1\end{array}$ & $\begin{array}{c}\text { Station } \\
2\end{array}$ & $\begin{array}{c}\text { Station } \\
1\end{array}$ & $\begin{array}{c}\text { Station } \\
2\end{array}$ \\
\hline $\begin{array}{c}2: 16: 00 \\
\text { PM }\end{array}$ & 527 & 563 & 4938 & 501 & 992 & 1325 & 161 & 1750 & 768 & 1399 & 1493 & 1694 \\
\hline $\begin{array}{c}2: 17: 00 \\
\text { PM }\end{array}$ & 545 & 555 & 4901 & 778 & 924 & 1326 & 156 & 2103 & 777 & 1377 & 1488 & 2037 \\
\hline $\begin{array}{c}2: 18: 00 \\
\text { PM }\end{array}$ & 588 & 568 & 5208 & 1608 & 1136 & 1308 & 153 & 2054 & 776 & 1359 & 1454 & 3880 \\
\hline $\begin{array}{c}2: 19: 00 \\
\text { PM }\end{array}$ & 646 & 612 & 5087 & 1851 & 907 & 1281 & 153 & 2041 & 769 & 1337 & 1400 & 4214 \\
\hline $\begin{array}{c}2: 20: 00 \\
\text { PM }\end{array}$ & 565 & 693 & 4935 & 1893 & 875 & 1273 & 152 & 1950 & 769 & 1333 & 1328 & 3619 \\
\hline $\begin{array}{c}2: 21: 00 \\
\text { PM }\end{array}$ & 358 & 878 & 4876 & 1910 & 864 & 1268 & 149 & 2079 & 767 & 1589 & 1272 & 2237 \\
\hline $\begin{array}{c}2: 23: 00 \\
\text { PM }\end{array}$ & 666 & 690 & 3726 & 1931 & 811 & 1254 & 139 & 2172 & 761 & 1818 & 1262 & 2209 \\
\hline $\begin{array}{c}2: 24: 00 \\
\text { PM }\end{array}$ & 591 & 591 & 5290 & 1925 & 848 & 1270 & 137 & 2081 & 755 & 2051 & 1296 & 1968 \\
\hline $\begin{array}{c}2: 25: 00 \\
\text { PM }\end{array}$ & 641 & 580 & 5102 & 1928 & 797 & 1244 & 135 & 1890 & 758 & 2315 & 1345 & 2494 \\
\hline $\begin{array}{c}2: 26: 00 \\
\text { PM }\end{array}$ & 710 & 580 & 5052 & 1918 & 874 & 1247 & 133 & 2182 & 757 & 1679 & 1348 & 2280 \\
\hline $\begin{array}{c}2: 27: 00 \\
\text { PM }\end{array}$ & 733 & 582 & 4958 & 1915 & 1163 & 1243 & 127 & 2038 & 754 & 1441 & 1335 & 1855 \\
\hline $\begin{array}{c}2: 28: 00 \\
\text { PM }\end{array}$ & 695 & 593 & 4975 & 1913 & 1166 & 1242 & 125 & 2238 & 750 & 1361 & 1316 & 1625 \\
\hline $\begin{array}{c}2: 29: 00 \\
\text { PM }\end{array}$ & 670 & 607 & 5040 & 1904 & 1146 & 1234 & 117 & 1960 & 752 & 1348 & 1300 & 1913 \\
\hline $\begin{array}{c}2: 31: 00 \\
\text { PM }\end{array}$ & 647 & 622 & 4911 & 1844 & 1201 & 1248 & 110 & 2317 & 737 & 1328 & 1263 & 1663 \\
\hline $\begin{array}{c}2: 32: 00 \\
\text { PM }\end{array}$ & 905 & 641 & 4880 & 1833 & 1140 & 1241 & 105 & 1972 & 732 & 1465 & 1238 & 1659 \\
\hline $\begin{array}{c}2: 33: 00 \\
\text { PM }\end{array}$ & 682 & 639 & 4783 & 1789 & 1939 & 1249 & 101 & 1907 & 732 & 1477 & 1222 & 1485 \\
\hline $\begin{array}{c}2: 34: 00 \\
\text { PM }\end{array}$ & 524 & 943 & 4180 & 1767 & 3917 & 1243 & 99 & 1902 & 709 & 1426 & 1208 & 1528 \\
\hline $\begin{array}{c}2: 35: 00 \\
\text { PM }\end{array}$ & 493 & 937 & 4284 & 1736 & 3008 & 1230 & 101 & 1865 & 713 & 1521 & 1206 & 1750 \\
\hline $\begin{array}{c}2: 36: 00 \\
\text { PM }\end{array}$ & 1229 & 918 & 6973 & 1684 & 1683 & 1232 & 96 & 1992 & 712 & 3083 & 1205 & 1517 \\
\hline $\begin{array}{c}2: 37: 00 \\
\text { PM }\end{array}$ & 1100 & 904 & 5215 & 1661 & 1257 & 1241 & 95 & 2927 & 707 & 1844 & 1246 & 1667 \\
\hline $\begin{array}{c}2: 38: 00 \\
\text { PM }\end{array}$ & 1075 & 932 & 4919 & 1603 & 1571 & 1228 & 95 & 2669 & 708 & 1470 & 1352 & 1803 \\
\hline $\begin{array}{c}2: 39: 00 \\
\text { PM }\end{array}$ & 1160 & 1080 & 5465 & 1517 & 1260 & 1210 & 121 & 3439 & 706 & 1438 & 1294 & 1798 \\
\hline $\begin{array}{c}2: 40: 00 \\
\text { PM }\end{array}$ & 1162 & 1111 & 5629 & 1531 & 1112 & 1202 & 144 & 2608 & 708 & 1398 & 1276 & 1637 \\
\hline $\begin{array}{c}2: 41: 00 \\
\text { PM }\end{array}$ & 979 & 995 & 5178 & 1465 & 1117 & 1192 & 142 & 2224 & 716 & 1351 & 1253 & 1794 \\
\hline $\begin{array}{c}2: 42: 00 \\
\text { PM }\end{array}$ & 950 & 980 & 5133 & 1443 & 1088 & 1191 & 141 & 2204 & 717 & 1449 & 1266 & 1745 \\
\hline $\begin{array}{c}2: 43: 00 \\
\text { PM }\end{array}$ & 944 & 950 & 5329 & 1454 & 1087 & 1192 & 142 & 2794 & 712 & 1863 & 1270 & 1805 \\
\hline $\begin{array}{c}2: 44: 00 \\
\text { PM }\end{array}$ & 1051 & 994 & 5666 & 1410 & 1075 & 1185 & 141 & 3356 & 931 & 1907 & 1294 & 1967 \\
\hline
\end{tabular}




\begin{tabular}{|c|c|c|c|c|c|c|c|c|c|c|}
\hline \multirow[b]{2}{*}{ Time } & \multicolumn{2}{|c|}{ 20-Sept (cont.) } & \multicolumn{2}{|c|}{ 21-Sept (cont.) } & \multicolumn{2}{|c|}{ 29-Sept (cont.) } & \multicolumn{2}{|c|}{ 30-Sept (cont.) } & \multicolumn{2}{|c|}{ 3-Oct (cont.) } \\
\hline & $\begin{array}{c}\text { Station } \\
1\end{array}$ & $\begin{array}{c}\text { Station } \\
2\end{array}$ & $\begin{array}{c}\text { Station } \\
1\end{array}$ & $\begin{array}{c}\text { Station } \\
2\end{array}$ & $\begin{array}{c}\text { Station } \\
1\end{array}$ & $\begin{array}{c}\text { Station } \\
2\end{array}$ & $\begin{array}{c}\text { Station } \\
1\end{array}$ & $\begin{array}{l}\text { Station } \\
2\end{array}$ & $\begin{array}{c}\text { Station } \\
1\end{array}$ & $\begin{array}{c}\text { Station } \\
2\end{array}$ \\
\hline $\begin{array}{c}2: 45: 00 \\
\text { PM }\end{array}$ & 988 & 914 & 4847 & 1356 & 1083 & 1165 & 140 & 3893 & 1290 & 2737 \\
\hline $\begin{array}{c}2: 46: 00 \\
\text { PM }\end{array}$ & 971 & 950 & 4491 & 1300 & 1073 & 1149 & 139 & 4510 & 1295 & 4109 \\
\hline $\begin{array}{c}2: 47: 00 \\
\text { PM }\end{array}$ & 838 & 911 & 5734 & 1247 & 1073 & 1130 & 140 & 3687 & 1292 & 5242 \\
\hline $\begin{array}{c}2: 48: 00 \\
\text { PM }\end{array}$ & 568 & 899 & 5120 & 1118 & 1037 & 1135 & 140 & 4166 & 1283 & 4068 \\
\hline $\begin{array}{c}2: 49: 00 \\
\text { PM }\end{array}$ & 441 & 824 & 5055 & 942 & 1122 & 1122 & 142 & 5672 & 1327 & 3185 \\
\hline $\begin{array}{c}2: 50: 00 \\
\text { PM }\end{array}$ & 321 & 798 & 4921 & 728 & 1046 & 1100 & 144 & 7161 & 1514 & 7663 \\
\hline $\begin{array}{c}2: 52: 00 \\
\text { PM }\end{array}$ & 693 & 950 & 4772 & 344 & 1003 & 1091 & 144 & 7973 & 1717 & 5964 \\
\hline $\begin{array}{c}2: 53: 00 \\
\text { PM }\end{array}$ & 612 & 976 & 4770 & 199 & 976 & 1083 & 142 & 6946 & 2179 & 3692 \\
\hline $\begin{array}{c}2: 54: 00 \\
\text { PM }\end{array}$ & 536 & 933 & 4764 & 106 & 981 & 1089 & 145 & 5780 & 3085 & 3722 \\
\hline $\begin{array}{c}2: 55: 00 \\
\text { PM }\end{array}$ & 629 & 985 & 4718 & 54 & 969 & 1069 & 148 & 5039 & 3785 & 2635 \\
\hline $\begin{array}{c}2: 56: 00 \\
\text { PM }\end{array}$ & 886 & 1028 & 4246 & 31 & 968 & 1050 & 153 & 4914 & 4116 & 3143 \\
\hline $\begin{array}{c}2: 57: 00 \\
\text { PM }\end{array}$ & 931 & 998 & 3770 & 18 & 13884 & 1034 & 153 & 4790 & 4781 & 3280 \\
\hline $\begin{array}{c}2: 58: 00 \\
\text { PM }\end{array}$ & 919 & 956 & 4998 & 10 & 23245 & 1037 & 154 & 4726 & 5536 & 4896 \\
\hline $\begin{array}{c}\text { 3:00:00 } \\
\text { PM }\end{array}$ & 943 & 931 & 4643 & 4 & 1162 & 1043 & 153 & 5251 & 6657 & 3748 \\
\hline $\begin{array}{c}\text { 3:01:00 } \\
\text { PM }\end{array}$ & 873 & 891 & 4567 & 3 & 1137 & 1036 & 164 & 4749 & 6064 & 2046 \\
\hline $\begin{array}{c}3: 02: 00 \\
\text { PM }\end{array}$ & 891 & 876 & 4541 & 2 & 1041 & 1023 & 389 & 4791 & 4506 & 2061 \\
\hline $\begin{array}{c}3: 03: 00 \\
\text { PM }\end{array}$ & 847 & 935 & 4499 & 2 & 997 & 997 & 311 & 4552 & 3405 & 2686 \\
\hline $\begin{array}{c}\text { 3:04:00 } \\
\text { PM }\end{array}$ & 888 & 880 & 4440 & 2 & 993 & 936 & 253 & 4958 & 2140 & 2282 \\
\hline $\begin{array}{c}\text { 3:05:00 } \\
\text { PM }\end{array}$ & 917 & 2145 & 4457 & 1 & 3035 & 896 & 323 & 4554 & 1681 & 1796 \\
\hline $\begin{array}{c}3: 06: 00 \\
\text { PM }\end{array}$ & 989 & 3373 & 4415 & 1 & 1732 & 881 & 322 & 4503 & 1416 & 1822 \\
\hline $\begin{array}{c}3: 07: 00 \\
\text { PM }\end{array}$ & 1143 & 3146 & 4065 & 1 & 903 & 866 & 251 & 4604 & 1274 & 1752 \\
\hline $\begin{array}{c}3: 08: 00 \\
\text { PM }\end{array}$ & 1263 & 3008 & 3455 & 1 & 859 & 838 & 316 & 3502 & 1227 & 1705 \\
\hline $\begin{array}{c}3: 09: 00 \\
\text { PM }\end{array}$ & 1743 & 5893 & 4826 & 1 & 833 & 814 & 402 & 3416 & 1187 & 1720 \\
\hline $\begin{array}{c}3: 10: 00 \\
\text { PM }\end{array}$ & 1951 & 9962 & 4301 & 1 & 845 & 820 & 370 & 3788 & 1150 & 1551 \\
\hline $\begin{array}{c}3: 11: 00 \\
\text { PM }\end{array}$ & 2119 & 4529 & 4355 & 1 & 852 & 839 & 421 & 3707 & 1144 & 1568 \\
\hline $\begin{array}{c}3: 12: 00 \\
\text { PM }\end{array}$ & 2073 & 4033 & 4361 & 1 & 971 & 843 & 533 & 3555 & 1130 & 1511 \\
\hline $\begin{array}{c}3: 13: 00 \\
\text { PM }\end{array}$ & 1201 & 5905 & 4413 & 1 & 855 & 860 & 583 & 3593 & 1129 & 2039 \\
\hline
\end{tabular}




\begin{tabular}{|c|c|c|c|c|c|c|c|c|c|c|}
\hline \multirow[b]{2}{*}{ Time } & \multicolumn{2}{|c|}{ 20-Sept (cont.) } & \multicolumn{2}{|c|}{ 21-Sept (cont.) } & \multicolumn{2}{|c|}{ 29-Sept (cont.) } & \multicolumn{2}{|c|}{ 30-Sept (cont.) } & \multicolumn{2}{|c|}{ 3-Oct (cont.) } \\
\hline & $\begin{array}{c}\text { Station } \\
1\end{array}$ & $\begin{array}{l}\text { Station } \\
2\end{array}$ & $\begin{array}{c}\text { Station } \\
1\end{array}$ & $\begin{array}{c}\text { Station } \\
2\end{array}$ & $\begin{array}{l}\text { Station } \\
1\end{array}$ & $\begin{array}{l}\text { Station } \\
2\end{array}$ & $\begin{array}{c}\text { Station } \\
1\end{array}$ & $\begin{array}{l}\text { Station } \\
2\end{array}$ & $\begin{array}{c}\text { Station } \\
1\end{array}$ & $\begin{array}{c}\text { Station } \\
2\end{array}$ \\
\hline $\begin{array}{c}3: 14: 00 \\
\text { PM }\end{array}$ & 1880 & 4609 & 4373 & 1 & 831 & 860 & 566 & 3604 & 1097 & 1818 \\
\hline $\begin{array}{c}\text { 3:15:00 } \\
\text { PM }\end{array}$ & 1481 & 4110 & 4267 & 3 & 833 & 864 & 377 & 4003 & 1087 & 2004 \\
\hline $\begin{array}{c}3: 16: 00 \\
\text { PM }\end{array}$ & 18 & 4404 & 4261 & 1 & 840 & 878 & 631 & 4865 & 1070 & 1566 \\
\hline $\begin{array}{c}\text { 3:17:00 } \\
\text { PM }\end{array}$ & 0 & 3871 & & & 2259 & 872 & 783 & 5555 & 1067 & 1451 \\
\hline $\begin{array}{c}3: 18: 00 \\
\text { PM }\end{array}$ & 0 & 5049 & & & 3646 & 856 & 929 & 3848 & 1062 & 1583 \\
\hline $\begin{array}{c}\text { 3:19:00 } \\
\text { PM }\end{array}$ & 0 & 5048 & & & 11742 & 858 & 810 & 3909 & 1038 & 1583 \\
\hline $\begin{array}{c}: 20: 00 \\
\text { PM }\end{array}$ & 0 & 4836 & & & 4360 & 864 & 725 & 3354 & 1054 & 1876 \\
\hline $\begin{array}{c}3: 21: 00 \\
\text { PM }\end{array}$ & 352 & 4509 & & & 1436 & 858 & 685 & 3721 & 1062 & 1686 \\
\hline $\begin{array}{c}3: 22: 00 \\
\text { PM }\end{array}$ & 784 & 5049 & & & 877 & 876 & 574 & 4130 & 1070 & 1478 \\
\hline $\begin{array}{c}\text { 3:23:00 } \\
\text { PM }\end{array}$ & 815 & 5119 & & & 819 & 907 & 509 & 4633 & 1099 & 1529 \\
\hline $\begin{array}{c}3: 24: 00 \\
\text { PM }\end{array}$ & 786 & 4264 & & & 820 & 910 & 333 & 8516 & 1113 & 1506 \\
\hline $\begin{array}{c}3: 25: 00 \\
\text { PM }\end{array}$ & & & & & 881 & 930 & 355 & 6153 & 1126 & 1420 \\
\hline $\begin{array}{c}3: 26: 00 \\
\text { PM }\end{array}$ & & & & & 911 & 917 & 949 & 5121 & 1136 & 1483 \\
\hline $\begin{array}{c}3: 27: 00 \\
\text { PM }\end{array}$ & & & & & 881 & 927 & 929 & 4302 & 1125 & 1440 \\
\hline $\begin{array}{c}3: 28: 00 \\
\text { PM }\end{array}$ & & & & & 869 & 951 & 865 & 3997 & 1118 & 1434 \\
\hline $\begin{array}{c}3: 29: 00 \\
\text { PM }\end{array}$ & & & & & 1906 & 986 & 878 & 6128 & 1093 & 1428 \\
\hline $\begin{array}{c}\text { 3:30:00 } \\
\text { PM }\end{array}$ & & & & & 14007 & 1001 & 871 & 6601 & 1077 & 1391 \\
\hline $\begin{array}{c}3: 31: 00 \\
\text { PM }\end{array}$ & & & & & 5935 & 999 & 858 & 5763 & 1060 & 1397 \\
\hline $\begin{array}{c}\text { 3:32:00 } \\
\text { PM }\end{array}$ & & & & & 16344 & 1011 & 858 & 8156 & 1051 & 1353 \\
\hline $\begin{array}{c}3: 33: 00 \\
\text { PM }\end{array}$ & & & & & 2618 & 1015 & 862 & 6130 & 1033 & 1333 \\
\hline $\begin{array}{c}3: 34: 00 \\
\text { PM }\end{array}$ & & & & & 1101 & 993 & 859 & 5241 & 1012 & 1383 \\
\hline $\begin{array}{c}3: 35: 00 \\
\text { PM }\end{array}$ & & & & & 919 & 984 & 878 & 5166 & 1013 & 1358 \\
\hline $\begin{array}{c}\text { 3:36:00 } \\
\text { PM }\end{array}$ & & & & & 956 & 978 & 910 & 3921 & 1018 & 2083 \\
\hline $\begin{array}{c}3: 37: 00 \\
\text { PM }\end{array}$ & & & & & 914 & 1011 & 908 & 4343 & 1016 & 2362 \\
\hline $\begin{array}{c}3: 38: 00 \\
\text { PM }\end{array}$ & & & & & 1024 & 1024 & & & 1005 & 1918 \\
\hline $\begin{array}{c}3: 39: 00 \\
\text { PM }\end{array}$ & & & & & 999 & 1020 & & & 1017 & 1725 \\
\hline $\begin{array}{c}\text { 3:40:00 } \\
\text { PM }\end{array}$ & & & & & 901 & 3767 & & & 1012 & 1649 \\
\hline $\begin{array}{c}: 41: 00 \\
\text { PM }\end{array}$ & & & & & & & & & 1005 & 1752 \\
\hline $\begin{array}{c}3: 42: 00 \\
\text { PM }\end{array}$ & & & & & & & & & 986 & 1561 \\
\hline
\end{tabular}




\begin{tabular}{|c|c|c|}
\hline & \multicolumn{2}{|c|}{ 3-Oct (cont.) } \\
\hline Time & $\begin{array}{c}\text { Station } \\
1\end{array}$ & $\begin{array}{c}\text { Station } \\
2\end{array}$ \\
\hline $\begin{array}{c}3: 43: 00 \\
\text { PM }\end{array}$ & 976 & 1823 \\
\hline $\begin{array}{c}3: 44: 00 \\
\text { PM }\end{array}$ & 955 & 1802 \\
\hline
\end{tabular}




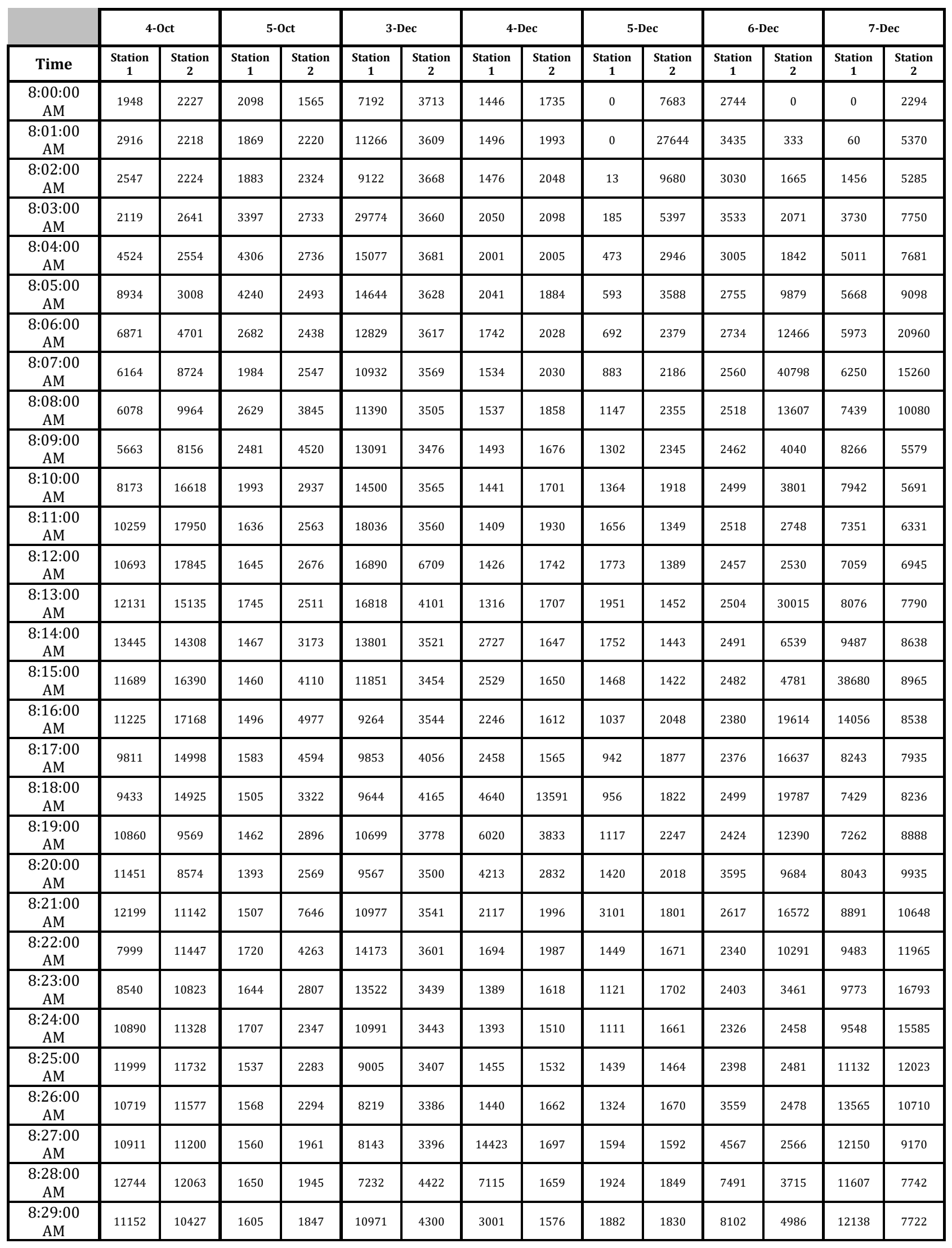




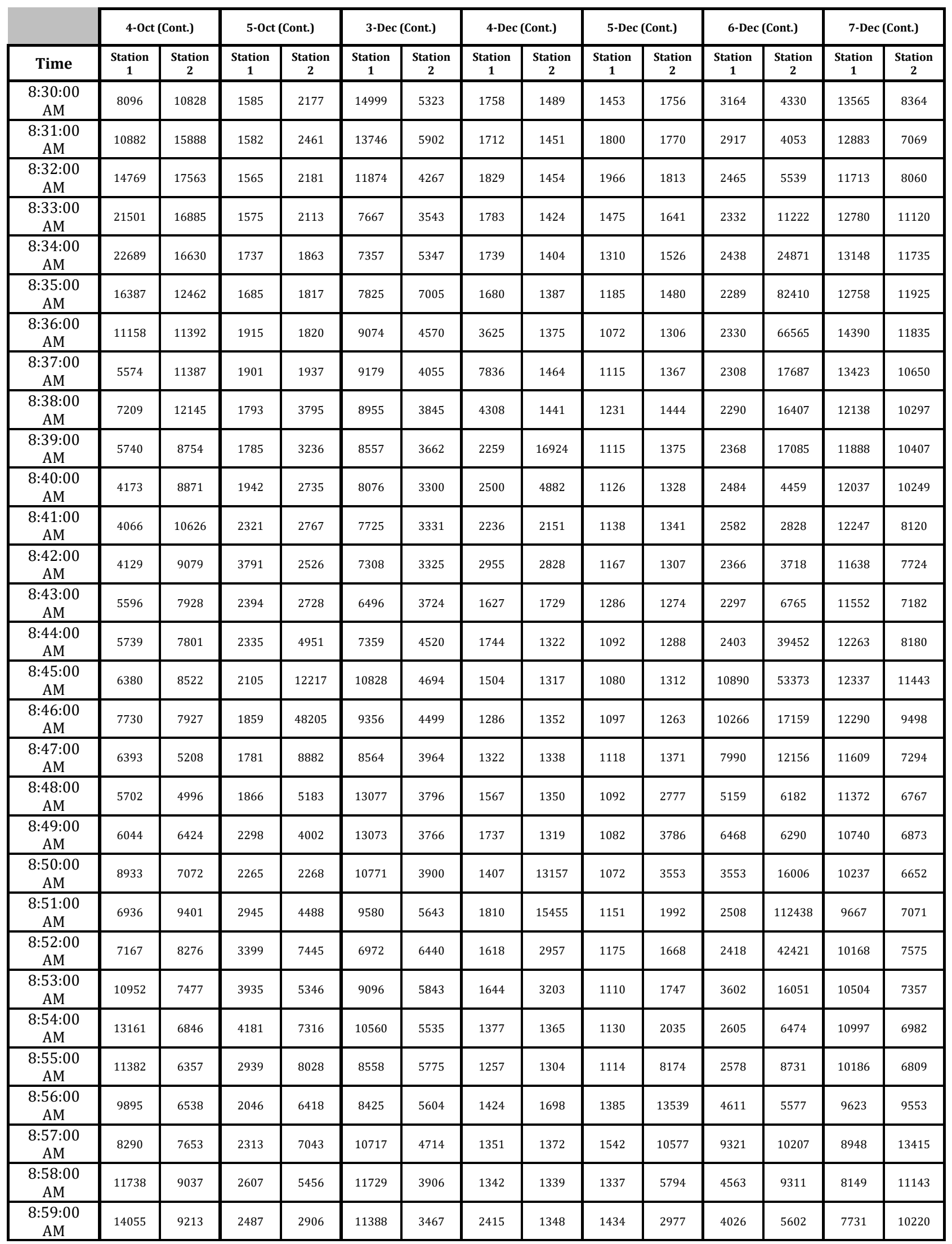




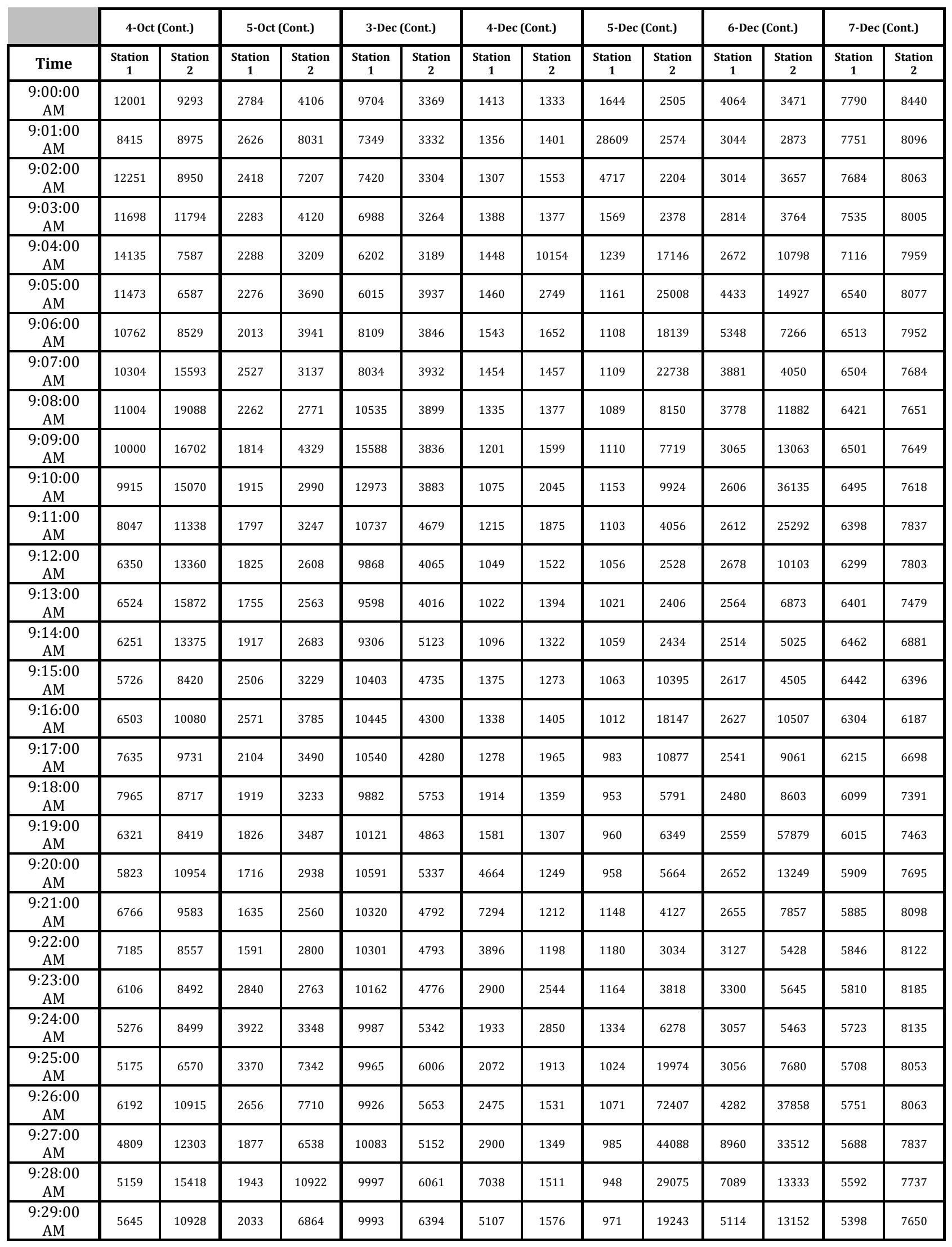




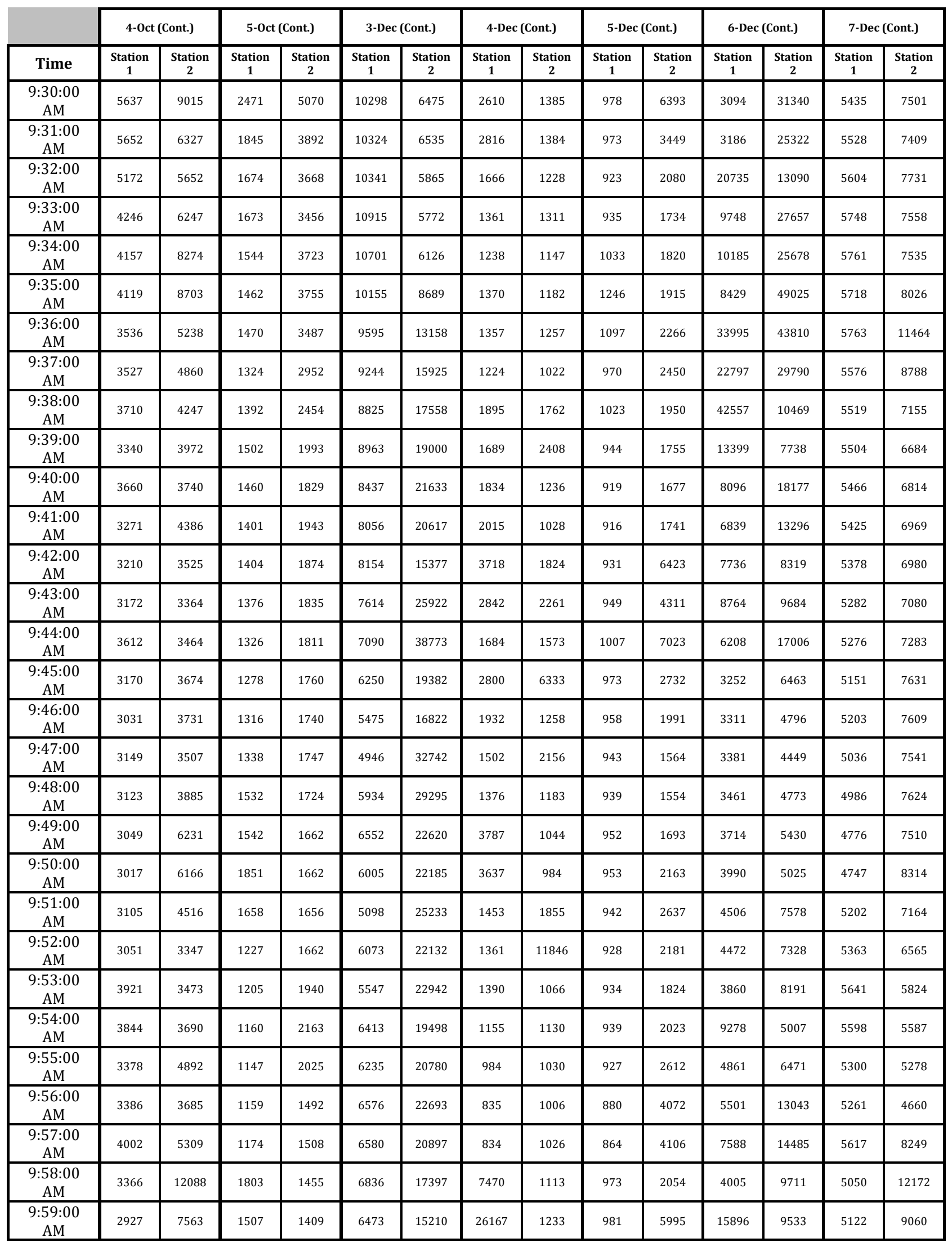




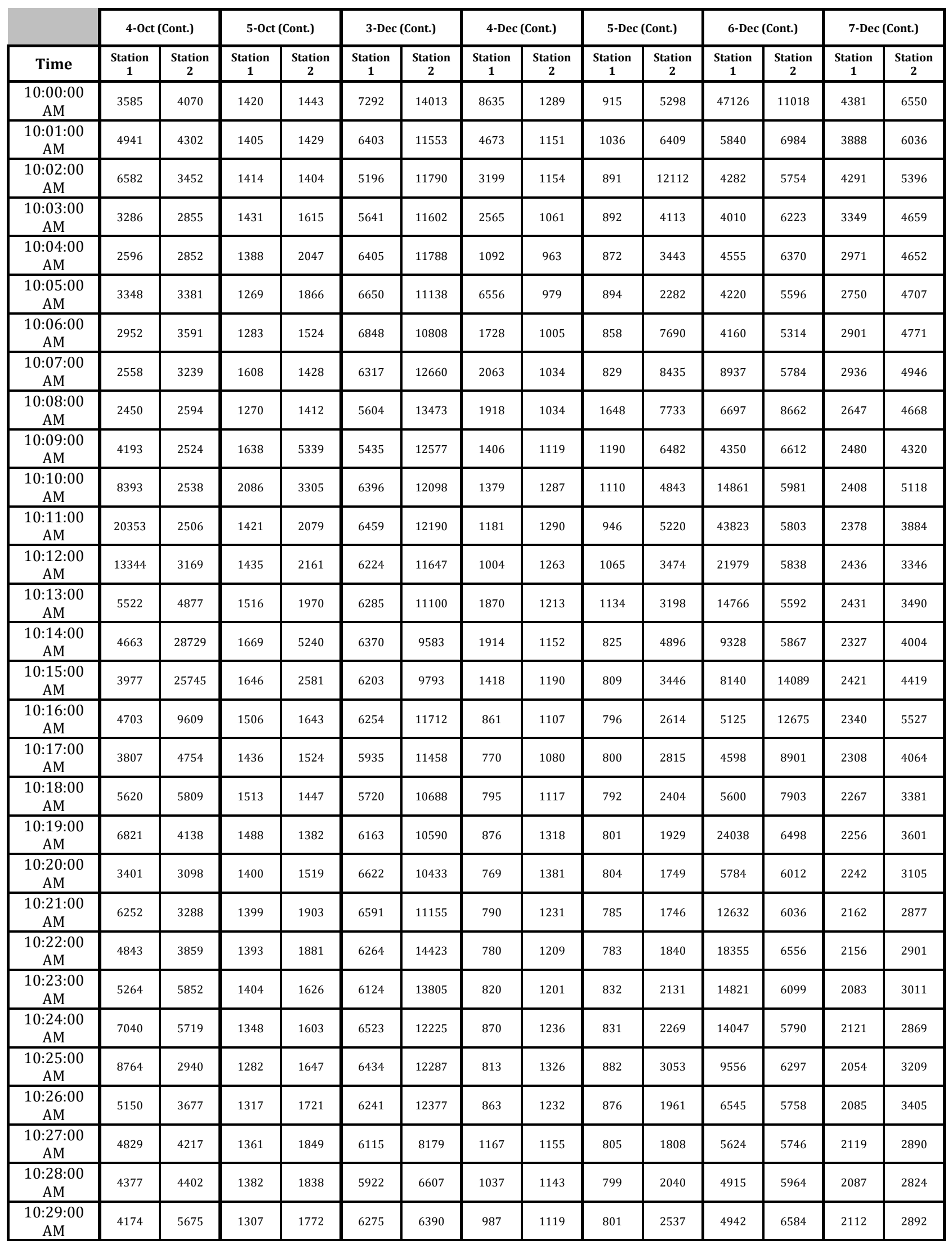




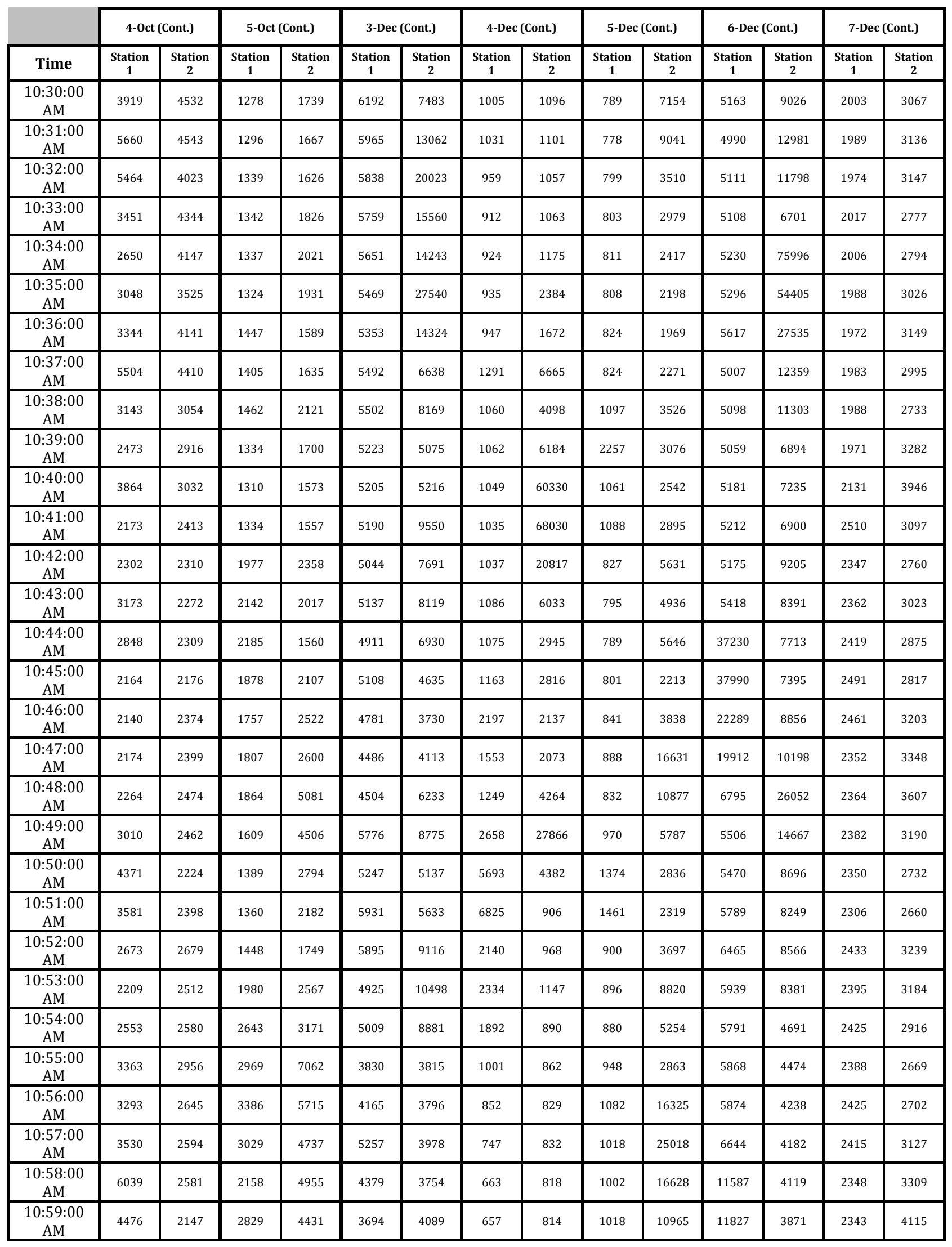




\begin{tabular}{|c|c|c|c|c|c|c|c|c|c|c|c|c|c|c|}
\hline \multirow[b]{2}{*}{ Time } & \multicolumn{2}{|c|}{ 4-Oct (Cont.) } & \multicolumn{2}{|c|}{ 5-Oct (Cont.) } & \multicolumn{2}{|c|}{ 3-Dec (Cont.) } & \multicolumn{2}{|c|}{ 4-Dec (Cont.) } & \multicolumn{2}{|c|}{ 5-Dec (Cont.) } & \multicolumn{2}{|c|}{ 6-Dec (Cont.) } & \multicolumn{2}{|c|}{ 7-Dec (Cont.) } \\
\hline & $\begin{array}{c}\text { Station } \\
1\end{array}$ & $\begin{array}{l}\text { Station } \\
2\end{array}$ & $\begin{array}{c}\text { Station } \\
1\end{array}$ & $\begin{array}{c}\text { Station } \\
2\end{array}$ & $\begin{array}{c}\text { Station } \\
1\end{array}$ & $\begin{array}{c}\text { Station } \\
2\end{array}$ & $\begin{array}{c}\text { Station } \\
1\end{array}$ & $\begin{array}{l}\text { Station } \\
2\end{array}$ & $\begin{array}{l}\text { Station } \\
\quad 1\end{array}$ & $\begin{array}{l}\text { Station } \\
2\end{array}$ & $\begin{array}{c}\text { Station } \\
1\end{array}$ & $\begin{array}{l}\text { Station } \\
2\end{array}$ & $\begin{array}{c}\text { Station } \\
1\end{array}$ & $\begin{array}{l}\text { Station } \\
2\end{array}$ \\
\hline $\begin{array}{c}11: 00: 00 \\
\text { AM }\end{array}$ & 4632 & 2040 & 1691 & 4008 & 3666 & 3815 & 597 & 829 & 1015 & 7000 & 10468 & 4323 & 2311 & 2881 \\
\hline $\begin{array}{c}11: 01: 00 \\
\text { AM }\end{array}$ & 2839 & 2105 & 1368 & 4428 & 2522 & 3903 & 613 & 814 & 1758 & 2341 & 10288 & 4038 & 2331 & 2988 \\
\hline $\begin{array}{c}11: 03: 00 \\
\text { AM }\end{array}$ & 2222 & 2163 & 1338 & 3303 & 2247 & 3740 & 617 & 816 & 1031 & 2247 & 6219 & 4504 & 2354 & 3897 \\
\hline $\begin{array}{c}11: 04: 00 \\
\text { AM }\end{array}$ & 2183 & 2262 & 1289 & 1936 & 2177 & 3455 & 621 & 836 & 1083 & 1913 & 4722 & 3510 & 2432 & 3458 \\
\hline $\begin{array}{c}11: 05: 00 \\
\text { AM }\end{array}$ & 2115 & 4048 & 1285 & 1619 & 2742 & 3471 & 586 & 886 & 1221 & 1990 & 4078 & 3591 & 2366 & 2944 \\
\hline $\begin{array}{c}11: 07: 00 \\
\text { AM }\end{array}$ & 2158 & 2091 & 1301 & 1616 & 3458 & 3674 & 1459 & 921 & 1147 & 2388 & 3131 & 3328 & 2452 & 5498 \\
\hline $\begin{array}{c}11: 08: 00 \\
\text { AM }\end{array}$ & 2034 & 2099 & 1301 & 1556 & 3241 & 3739 & 1177 & 965 & 1077 & 2389 & 3209 & 3437 & 2418 & 7240 \\
\hline $\begin{array}{c}11: 09: 00 \\
\text { AM }\end{array}$ & 2273 & 2095 & 1243 & 1517 & 3193 & 3713 & 777 & 962 & 1083 & 3488 & 3313 & 3552 & 2436 & 3692 \\
\hline $\begin{array}{c}11: 10: 00 \\
\text { AM }\end{array}$ & 2249 & 2058 & 1282 & 1536 & 2890 & 3682 & 603 & 966 & 1011 & 2770 & 4057 & 3738 & 2350 & 3739 \\
\hline $\begin{array}{c}11: 11: 00 \\
\text { AM }\end{array}$ & 3465 & 2057 & 1506 & 1540 & 1755 & 3416 & 603 & 1297 & 999 & 2469 & 3410 & 3736 & 2340 & 3520 \\
\hline $\begin{array}{c}11: 12: 00 \\
\text { AM }\end{array}$ & 1820 & 3067 & 1499 & 2288 & 1649 & 3535 & 619 & 1213 & 1015 & 2352 & 3289 & 3675 & 2407 & 3123 \\
\hline $\begin{array}{c}11: 13: 00 \\
\text { AM }\end{array}$ & 2178 & 4819 & 1450 & 2251 & 1606 & 3589 & 855 & 1047 & 1108 & 2619 & 3233 & 3568 & 2308 & 3298 \\
\hline $\begin{array}{c}11: 15: 00 \\
\text { AM }\end{array}$ & 2496 & 2316 & 1435 & 1616 & 1619 & 3408 & 702 & 1029 & 1263 & 2123 & 3071 & 3573 & 2347 & 2821 \\
\hline $\begin{array}{c}11: 16: 00 \\
\text { AM }\end{array}$ & 2234 & 2205 & 1305 & 1642 & 1606 & 3426 & 771 & 1077 & 1112 & 2087 & 2887 & 3559 & 2311 & 4408 \\
\hline $\begin{array}{c}11: 17: 00 \\
\text { AM }\end{array}$ & 2298 & 2262 & 1301 & 1662 & 1613 & 3417 & 764 & 1199 & 1011 & 2424 & 2926 & 3561 & 2349 & 3868 \\
\hline $\begin{array}{c}11: 18: 00 \\
\text { AM }\end{array}$ & 2169 & 2152 & 1501 & 1590 & 1546 & 3495 & 746 & 1270 & 1072 & 2323 & 3090 & 3330 & 2489 & 2893 \\
\hline $\begin{array}{c}11: 19: 00 \\
\text { AM }\end{array}$ & 1694 & 2132 & 1559 & 1414 & 1627 & 4114 & 707 & 1288 & 1155 & 2324 & 3035 & 2907 & 2459 & 2831 \\
\hline $\begin{array}{c}11: 20: 00 \\
\text { AM }\end{array}$ & 2264 & 2102 & 1446 & 1398 & 1525 & 3440 & 670 & 1290 & 1117 & 2819 & 3062 & 2546 & 2395 & 4973 \\
\hline $\begin{array}{c}11: 21: 00 \\
\text { AM }\end{array}$ & 1739 & 2427 & 1431 & 1416 & 1499 & 3478 & & & 1098 & 2376 & 3173 & 2383 & 2347 & 3188 \\
\hline $\begin{array}{c}11: 22: 00 \\
\text { AM }\end{array}$ & 1792 & 2228 & 1494 & 1572 & 1478 & 3477 & & & & & 3237 & 2401 & 2384 & 3171 \\
\hline $\begin{array}{c}11: 23: 00 \\
\text { AM }\end{array}$ & 2152 & 2532 & 1460 & 1627 & 1487 & 3455 & & & & & 3149 & 2396 & 2465 & 3505 \\
\hline $\begin{array}{c}11: 24: 00 \\
\text { AM }\end{array}$ & 2132 & 3532 & 1483 & 1808 & 1497 & 3484 & & & & & 3068 & 2326 & 2577 & 3315 \\
\hline $\begin{array}{c}11: 25: 00 \\
\text { AM }\end{array}$ & 1927 & 3476 & 1469 & 1819 & 1486 & 3524 & & & & & 3174 & 2396 & 2523 & 3178 \\
\hline $\begin{array}{c}11: 26: 00 \\
\text { AM }\end{array}$ & 1630 & 3934 & & & 1505 & 3469 & & & & & 3204 & 2408 & 2427 & 29051 \\
\hline $\begin{array}{c}11: 27: 00 \\
\text { AM }\end{array}$ & 1694 & 3487 & & & 1468 & 3458 & & & & & 3237 & 2423 & 2366 & 39655 \\
\hline $\begin{array}{c}11: 28: 00 \\
\text { AM }\end{array}$ & 1922 & 2719 & & & 1443 & 3379 & & & & & 3086 & 2672 & 2412 & 15800 \\
\hline $\begin{array}{c}11: 29: 00 \\
\text { AM }\end{array}$ & 2472 & 2474 & & & 1441 & 3397 & & & & & 2826 & 2571 & 2418 & 7614 \\
\hline
\end{tabular}




\begin{tabular}{|c|c|c|}
\hline \multirow[b]{2}{*}{ Time } & \multicolumn{2}{|c|}{ 4-Oct (Cont.) } \\
\hline & $\begin{array}{c}\text { Station } \\
1\end{array}$ & $\begin{array}{c}\text { Station } \\
2\end{array}$ \\
\hline $\begin{array}{c}\text { 11:30:00 } \\
\text { AM }\end{array}$ & 1781 & 2254 \\
\hline $\begin{array}{c}11: 31: 00 \\
\text { AM }\end{array}$ & 3265 & 2147 \\
\hline $\begin{array}{c}11: 32: 00 \\
\text { AM }\end{array}$ & 1717 & 1827 \\
\hline $\begin{array}{c}11: 33: 00 \\
\text { AM }\end{array}$ & 2818 & 1817 \\
\hline $\begin{array}{c}11: 34: 00 \\
\text { AM }\end{array}$ & 2721 & 1881 \\
\hline $\begin{array}{c}11: 35: 00 \\
\text { AM }\end{array}$ & 1626 & 1653 \\
\hline $\begin{array}{c}11: 36: 00 \\
\text { AM }\end{array}$ & 1587 & 1982 \\
\hline $\begin{array}{c}11: 37: 00 \\
\text { AM }\end{array}$ & 1600 & 1987 \\
\hline $\begin{array}{c}11: 38: 00 \\
\text { AM }\end{array}$ & 2004 & 1740 \\
\hline $\begin{array}{c}11: 39: 00 \\
\text { AM }\end{array}$ & 1618 & 1756 \\
\hline $\begin{array}{c}11: 40: 00 \\
\text { AM }\end{array}$ & 1607 & 1528 \\
\hline $\begin{array}{c}11: 41: 00 \\
\text { AM }\end{array}$ & 1954 & 1507 \\
\hline $\begin{array}{c}11: 42: 00 \\
\text { AM }\end{array}$ & 1723 & 1542 \\
\hline $\begin{array}{c}\text { 11:43:00 } \\
\text { AM }\end{array}$ & 1705 & 1915 \\
\hline $\begin{array}{c}11: 44: 00 \\
\text { AM }\end{array}$ & 1792 & 2012 \\
\hline $\begin{array}{c}11: 45: 00 \\
\text { AM }\end{array}$ & 1945 & 1654 \\
\hline $\begin{array}{c}11: 46: 00 \\
\text { AM }\end{array}$ & 2034 & 1500 \\
\hline $\begin{array}{c}11: 47: 00 \\
\text { AM }\end{array}$ & 1712 & 4061 \\
\hline $\begin{array}{c}11: 48: 00 \\
\text { AM }\end{array}$ & 1724 & 7695 \\
\hline $\begin{array}{c}11: 49: 00 \\
\text { AM }\end{array}$ & 1653 & 7634 \\
\hline $\begin{array}{c}11: 50: 00 \\
\text { AM }\end{array}$ & 1647 & 7663 \\
\hline $\begin{array}{c}11: 51: 00 \\
\text { AM }\end{array}$ & 1641 & 7525 \\
\hline $\begin{array}{c}11: 52: 00 \\
\text { AM }\end{array}$ & 1653 & 6986 \\
\hline $\begin{array}{c}11: 53: 00 \\
\text { AM }\end{array}$ & 1718 & 6480 \\
\hline $\begin{array}{c}11: 54: 00 \\
\text { AM }\end{array}$ & 1708 & 3371 \\
\hline $\begin{array}{c}11: 55: 00 \\
\text { AM }\end{array}$ & 1673 & 863 \\
\hline $\begin{array}{c}11: 56: 00 \\
\text { AM }\end{array}$ & 1662 & 863 \\
\hline $\begin{array}{c}11: 57: 00 \\
\text { AM }\end{array}$ & 1772 & 730 \\
\hline $\begin{array}{c}11: 58: 00 \\
\text { AM }\end{array}$ & 1733 & 784 \\
\hline $\begin{array}{c}\text { 11:59:00 } \\
\text { AM }\end{array}$ & 1683 & 1236 \\
\hline
\end{tabular}

\begin{tabular}{|c|c|}
\hline \multicolumn{2}{|c|}{ 3-Dec (Cont.) } \\
\hline $\begin{array}{c}\text { Station } \\
1\end{array}$ & $\begin{array}{c}\text { Station } \\
2\end{array}$ \\
\hline 1464 & 3408 \\
\hline 1449 & 3434 \\
\hline 1438 & 4664 \\
\hline 1432 & 7944 \\
\hline 1435 & 4557 \\
\hline 1437 & 3629 \\
\hline 1449 & 3551 \\
\hline 1440 & 3532 \\
\hline 1552 & 3463 \\
\hline 1447 & 3882 \\
\hline 1420 & 3948 \\
\hline 1414 & 3576 \\
\hline 1421 & 3459 \\
\hline 1432 & 3445 \\
\hline 1425 & 3511 \\
\hline 1434 & 3499 \\
\hline 1427 & 3477 \\
\hline 1446 & 3485 \\
\hline 1450 & 3432 \\
\hline 1447 & 3649 \\
\hline 1461 & 3722 \\
\hline 1469 & 3635 \\
\hline 1473 & 4749 \\
\hline 1464 & 3716 \\
\hline 1465 & 3757 \\
\hline 1635 & 3695 \\
\hline 1701 & 3608 \\
\hline 1515 & 3693 \\
\hline 1541 & 3687 \\
\hline 1542 & 3610 \\
\hline
\end{tabular}

\begin{tabular}{|c|c|c|c|}
\hline \multicolumn{2}{|c|}{ 6-Dec (Cont.) } & \multicolumn{2}{|c|}{ 7-Dec (Cont.) } \\
\hline $\begin{array}{c}\text { Station } \\
1\end{array}$ & $\begin{array}{l}\text { Station } \\
2\end{array}$ & $\begin{array}{c}\text { Station } \\
1\end{array}$ & $\begin{array}{c}\text { Station } \\
2\end{array}$ \\
\hline 2478 & 2447 & 2487 & 6458 \\
\hline 2407 & 2435 & 2759 & 4207 \\
\hline 2246 & 2442 & 2391 & 4216 \\
\hline 2208 & 3726 & 2350 & 4250 \\
\hline 2155 & 3118 & 2395 & 3342 \\
\hline 2143 & 2503 & 2361 & 2766 \\
\hline 2138 & 2502 & 2358 & 2556 \\
\hline 2181 & 2502 & 2463 & 2633 \\
\hline 2237 & 2363 & 2285 & 2833 \\
\hline 2293 & 2262 & 2277 & 2689 \\
\hline 2165 & 2141 & 2272 & 2379 \\
\hline 2163 & 2097 & 3358 & 2423 \\
\hline 2162 & 2088 & 5621 & 2447 \\
\hline 2186 & 2067 & 4766 & 2280 \\
\hline 2208 & 2061 & 4294 & 2639 \\
\hline 2250 & 2063 & 3238 & 2806 \\
\hline 2274 & 2062 & 2937 & 2728 \\
\hline 2317 & 2067 & 2623 & 2947 \\
\hline 2322 & 2162 & 2394 & 4118 \\
\hline 2241 & 2115 & 2314 & 4712 \\
\hline 2018 & 2128 & 2310 & 4589 \\
\hline 1958 & 2778 & 2278 & 2630 \\
\hline 1866 & 2547 & 2371 & 2257 \\
\hline 1925 & 2351 & 2297 & 16668 \\
\hline 2103 & 3283 & 2088 & 42062 \\
\hline 1905 & 2155 & 2094 & 9681 \\
\hline 1844 & 2082 & 2169 & 8277 \\
\hline 1865 & 4884 & 2210 & 5641 \\
\hline 1906 & 3814 & 2357 & 4120 \\
\hline 1999 & 3144 & 2126 & 3799 \\
\hline
\end{tabular}




\begin{tabular}{|c|c|c|}
\hline \multirow[b]{2}{*}{ Time } & \multicolumn{2}{|c|}{ 4-Oct (Cont.) } \\
\hline & $\begin{array}{c}\text { Station } \\
1\end{array}$ & $\begin{array}{l}\text { Station } \\
2\end{array}$ \\
\hline $\begin{array}{c}\text { 12:00:00 } \\
\text { PM }\end{array}$ & 1562 & 2096 \\
\hline $\begin{array}{c}12: 01: 00 \\
\text { PM }\end{array}$ & 1591 & 2192 \\
\hline $\begin{array}{c}12: 02: 00 \\
\text { PM }\end{array}$ & 1557 & 2167 \\
\hline $\begin{array}{c}12: 03: 00 \\
\text { PM }\end{array}$ & 1528 & 2018 \\
\hline $\begin{array}{c}12: 04: 00 \\
\text { PM }\end{array}$ & 1571 & 2062 \\
\hline $\begin{array}{c}\text { 12:05:00 } \\
\text { PM }\end{array}$ & 1789 & 1949 \\
\hline $\begin{array}{c}12: 06: 00 \\
\text { PM }\end{array}$ & 1702 & 1937 \\
\hline $\begin{array}{c}\text { 12:07:00 } \\
\text { PM }\end{array}$ & 1532 & 2007 \\
\hline $\begin{array}{c}\text { 12:08:00 } \\
\text { PM }\end{array}$ & 1533 & 2482 \\
\hline $\begin{array}{c}\text { 12:09:00 } \\
\text { PM }\end{array}$ & 1764 & 2300 \\
\hline $\begin{array}{c}\text { 12:10:00 } \\
\text { PM }\end{array}$ & 1833 & 3220 \\
\hline $\begin{array}{c}\text { 12:11:00 } \\
\text { PM }\end{array}$ & 1625 & 2502 \\
\hline $\begin{array}{c}\text { 12:12:00 } \\
\text { PM }\end{array}$ & 1542 & 5998 \\
\hline $\begin{array}{c}12: 13: 00 \\
\text { PM }\end{array}$ & 1551 & 3482 \\
\hline $\begin{array}{c}12: 14: 00 \\
\text { PM }\end{array}$ & 1727 & 4670 \\
\hline $\begin{array}{c}\text { 12:15:00 } \\
\text { PM }\end{array}$ & 1516 & 8572 \\
\hline $\begin{array}{c}12: 16: 00 \\
\text { PM }\end{array}$ & 1464 & 2039 \\
\hline $\begin{array}{c}12: 17: 00 \\
\text { PM }\end{array}$ & 1498 & 2013 \\
\hline $\begin{array}{c}\text { 12:18:00 } \\
\text { PM }\end{array}$ & 1991 & 2741 \\
\hline $\begin{array}{c}\text { 12:19:00 } \\
\text { PM }\end{array}$ & 2095 & 3511 \\
\hline $\begin{array}{c}12: 20: 00 \\
\text { PM }\end{array}$ & 1755 & 2093 \\
\hline $\begin{array}{c}12: 21: 00 \\
\text { PM }\end{array}$ & 1603 & 1860 \\
\hline $\begin{array}{c}\text { 12:22:00 } \\
\text { PM }\end{array}$ & 1550 & 1848 \\
\hline $\begin{array}{c}12: 23: 00 \\
\text { PM }\end{array}$ & 1403 & 1859 \\
\hline $\begin{array}{c}12: 24: 00 \\
\text { PM }\end{array}$ & 1356 & 2321 \\
\hline $\begin{array}{c}12: 25: 00 \\
\text { PM }\end{array}$ & 1422 & 1936 \\
\hline $\begin{array}{c}12: 26: 00 \\
\text { PM }\end{array}$ & 1481 & 2217 \\
\hline $\begin{array}{c}12: 27: 00 \\
\text { PM }\end{array}$ & 1616 & 1916 \\
\hline $\begin{array}{c}12: 28: 00 \\
\text { PM }\end{array}$ & 1772 & 1931 \\
\hline $\begin{array}{c}12: 29: 00 \\
\text { PM }\end{array}$ & 1836 & 1906 \\
\hline
\end{tabular}

\begin{tabular}{|c|c|}
\hline \multicolumn{2}{|c|}{ 3-Dec (Cont.) } \\
\hline $\begin{array}{c}\text { Station } \\
\mathbf{1}\end{array}$ & $\begin{array}{c}\text { Station } \\
\mathbf{2}\end{array}$ \\
\hline 1568 & 3565 \\
\hline 1587 & 3504 \\
\hline 5246 & 3474 \\
\hline 13219 & 3429 \\
\hline 13821 & 3457 \\
\hline 11625 & 3468 \\
\hline 2079 & 3516 \\
\hline 1769 & 3498 \\
\hline 1856 & 3475 \\
\hline 1768 & 3511 \\
\hline
\end{tabular}

\begin{tabular}{|c|c|c|c|}
\hline \multicolumn{2}{|c|}{ 6-Dec (Cont.) } & \multicolumn{2}{|c|}{ 7-Dec (Cont.) } \\
\hline $\begin{array}{c}\text { Station } \\
1\end{array}$ & $\begin{array}{c}\text { Station } \\
2\end{array}$ & $\begin{array}{c}\text { Station } \\
1\end{array}$ & $\begin{array}{c}\text { Station } \\
2\end{array}$ \\
\hline 2181 & 3688 & 2196 & 2986 \\
\hline 2161 & 8873 & 2359 & 2343 \\
\hline 2082 & 4835 & 2268 & 2215 \\
\hline 2065 & 2877 & 2294 & 2185 \\
\hline 2172 & 3202 & 2268 & 2490 \\
\hline 2018 & 2848 & 2160 & 2887 \\
\hline 1855 & 1973 & 2362 & 2657 \\
\hline 1847 & 1964 & 3089 & 2123 \\
\hline 2632 & 2006 & 5103 & 1972 \\
\hline 1932 & 2244 & 3652 & 2082 \\
\hline 3847 & 1982 & 2655 & 2148 \\
\hline 2464 & 2173 & 2641 & 3813 \\
\hline 1877 & 2389 & 2087 & 4228 \\
\hline 1715 & 2130 & 1861 & 3000 \\
\hline 3036 & 2011 & 1845 & 2044 \\
\hline 2342 & 1996 & 1988 & 1952 \\
\hline 1664 & 2026 & 1793 & 1827 \\
\hline 1650 & 2007 & 1778 & 1784 \\
\hline 1826 & 2023 & 1798 & 2010 \\
\hline 1799 & 2672 & 1841 & 2118 \\
\hline 1723 & 2176 & 1790 & 2017 \\
\hline 2437 & 2094 & 1837 & 2346 \\
\hline 3313 & 2080 & 1777 & 2708 \\
\hline 2756 & 2134 & 1738 & 3376 \\
\hline 2379 & 1926 & 1722 & 7494 \\
\hline 4195 & 1977 & 1739 & 3928 \\
\hline 3268 & 2172 & 1828 & 1980 \\
\hline 2248 & 7202 & 1873 & 3231 \\
\hline 6018 & 3830 & 3625 & 6076 \\
\hline 5063 & 5261 & 1815 & 6195 \\
\hline
\end{tabular}




\begin{tabular}{|c|c|c|}
\hline \multirow{2}{*}{ Time } & \multicolumn{2}{|c|}{ 4-Oct (Cont.) } \\
\hline & $\begin{array}{c}\text { Station } \\
1\end{array}$ & $\begin{array}{c}\text { Station } \\
2\end{array}$ \\
\hline $\begin{array}{c}\text { 12:30:00 } \\
\text { PM }\end{array}$ & 1779 & 2084 \\
\hline $\begin{array}{c}12: 31: 00 \\
\text { PM }\end{array}$ & 1643 & 2272 \\
\hline $\begin{array}{c}12: 32: 00 \\
\text { PM }\end{array}$ & 1600 & 2019 \\
\hline $\begin{array}{c}12: 33: 00 \\
\text { PM }\end{array}$ & 1606 & 2092 \\
\hline $\begin{array}{c}12: 34: 00 \\
\text { PM }\end{array}$ & 1653 & 2165 \\
\hline $\begin{array}{c}\text { 12:35:00 } \\
\text { PM }\end{array}$ & 1686 & 2333 \\
\hline $\begin{array}{c}\text { 12:36:00 } \\
\text { PM }\end{array}$ & 1634 & 2166 \\
\hline $\begin{array}{c}\text { 12:37:00 } \\
\text { PM }\end{array}$ & 1576 & 2354 \\
\hline $\begin{array}{c}\text { 12:38:00 } \\
\text { PM }\end{array}$ & 1479 & 2036 \\
\hline $\begin{array}{c}12: 39: 00 \\
\text { PM }\end{array}$ & 1499 & 2020 \\
\hline $\begin{array}{c}12: 40: 00 \\
\text { PM }\end{array}$ & 2601 & 1900 \\
\hline $\begin{array}{c}12: 41: 00 \\
\text { PM }\end{array}$ & 2569 & 1856 \\
\hline $\begin{array}{c}12: 42: 00 \\
\text { PM }\end{array}$ & 1949 & 1978 \\
\hline $\begin{array}{c}\text { 12:43:00 } \\
\text { PM }\end{array}$ & 12341 & 2103 \\
\hline $\begin{array}{c}12: 44: 00 \\
\text { PM }\end{array}$ & 18368 & 2209 \\
\hline $\begin{array}{c}12: 45: 00 \\
\text { PM }\end{array}$ & 7872 & 1977 \\
\hline $\begin{array}{c}12: 46: 00 \\
\text { PM }\end{array}$ & 3522 & 2152 \\
\hline $\begin{array}{c}12: 47: 00 \\
\text { PM }\end{array}$ & 2184 & 2931 \\
\hline $\begin{array}{c}\text { 12:48:00 } \\
\text { PM }\end{array}$ & 3222 & 2939 \\
\hline $\begin{array}{c}12: 49: 00 \\
\text { PM }\end{array}$ & 1995 & 2639 \\
\hline $\begin{array}{c}\text { 12:50:00 } \\
\text { PM }\end{array}$ & 1724 & 1896 \\
\hline $\begin{array}{c}12: 51: 00 \\
\text { PM }\end{array}$ & 1575 & 1705 \\
\hline $\begin{array}{c}\text { 12:52:00 } \\
\text { PM }\end{array}$ & 1543 & 2307 \\
\hline $\begin{array}{c}\text { 12:53:00 } \\
\text { PM }\end{array}$ & 1631 & 2317 \\
\hline $\begin{array}{c}12: 54: 00 \\
\text { PM }\end{array}$ & 2051 & 2061 \\
\hline $\begin{array}{c}12: 55: 00 \\
\text { PM }\end{array}$ & 1685 & 1941 \\
\hline $\begin{array}{c}12: 56: 00 \\
\text { PM }\end{array}$ & 1598 & 1819 \\
\hline $\begin{array}{c}12: 57: 00 \\
\text { PM }\end{array}$ & 1562 & 1764 \\
\hline $\begin{array}{c}\text { 12:58:00 } \\
\text { PM }\end{array}$ & 1674 & 1735 \\
\hline $\begin{array}{c}\text { 12:59:00 } \\
\text { PM }\end{array}$ & 1569 & 1750 \\
\hline
\end{tabular}

\begin{tabular}{|c|c|c|c|}
\hline \multicolumn{2}{|c|}{ 6-Dec (Cont.) } & \multicolumn{2}{|c|}{ 7-Dec (Cont.) } \\
\hline $\begin{array}{c}\text { Station } \\
1\end{array}$ & $\begin{array}{c}\text { Station } \\
2\end{array}$ & $\begin{array}{c}\text { Station } \\
1\end{array}$ & $\begin{array}{c}\text { Station } \\
2\end{array}$ \\
\hline 2261 & 6170 & 1732 & 5062 \\
\hline 2205 & 3767 & 1655 & 2390 \\
\hline 2122 & 2777 & 1947 & 1679 \\
\hline 2107 & 3051 & 1772 & 1619 \\
\hline 1848 & 2117 & 1994 & 1617 \\
\hline 1952 & 1994 & 2008 & 1648 \\
\hline 1763 & 2014 & 1641 & 2086 \\
\hline 1876 & 2062 & 1826 & 2160 \\
\hline 1725 & 2052 & 6519 & 2162 \\
\hline 2340 & 2831 & 2569 & 2380 \\
\hline 2478 & 3950 & 1629 & 2927 \\
\hline 2124 & 5079 & 1518 & 2384 \\
\hline \multirow[t]{18}{*}{2188} & 5141 & 1620 & 2632 \\
\hline & & 1676 & 2091 \\
\hline & & 1761 & 1721 \\
\hline & & 1738 & 1701 \\
\hline & & 1554 & 4261 \\
\hline & & 1496 & 4622 \\
\hline & & 1575 & 13042 \\
\hline & & 1645 & 9668 \\
\hline & & 1701 & 6150 \\
\hline & & 1572 & 5089 \\
\hline & & 1675 & 4262 \\
\hline & & 1553 & 3526 \\
\hline & & 1588 & 3466 \\
\hline & & 1658 & 3326 \\
\hline & & 7554 & 2273 \\
\hline & & 1965 & 6535 \\
\hline & & 1518 & 8272 \\
\hline & & 4478 & 4082 \\
\hline
\end{tabular}




\begin{tabular}{|c|c|c|}
\hline & \multicolumn{2}{|c|}{ 4-Oct (Cont.) } \\
\hline Time & $\begin{array}{c}\text { Station } \\
1\end{array}$ & $\begin{array}{c}\text { Station } \\
2\end{array}$ \\
\hline $\begin{array}{c}1: 00: 00 \\
\text { PM }\end{array}$ & 2955 & 1733 \\
\hline $\begin{array}{c}1: 01: 00 \\
\text { PM }\end{array}$ & 1879 & 1727 \\
\hline $\begin{array}{c}1: 02: 00 \\
\text { PM }\end{array}$ & 1665 & 1699 \\
\hline $\begin{array}{c}1: 03: 00 \\
\text { PM }\end{array}$ & 1548 & 1685 \\
\hline $\begin{array}{c}1: 04: 00 \\
\text { PM }\end{array}$ & 1873 & 1649 \\
\hline $\begin{array}{c}1: 05: 00 \\
\text { PM }\end{array}$ & 1919 & 1638 \\
\hline $\begin{array}{c}\text { 1:06:00 } \\
\text { PM }\end{array}$ & 1732 & 1673 \\
\hline $\begin{array}{c}1: 07: 00 \\
\text { PM }\end{array}$ & 1687 & 1668 \\
\hline $\begin{array}{c}1: 08: 00 \\
\text { PM }\end{array}$ & 3435 & 1701 \\
\hline $\begin{array}{c}1: 09: 00 \\
\text { PM }\end{array}$ & 4758 & 1695 \\
\hline $\begin{array}{c}1: 10: 00 \\
\text { PM }\end{array}$ & 2093 & 1687 \\
\hline $\begin{array}{c}1: 11: 00 \\
\text { PM }\end{array}$ & 1974 & 1862 \\
\hline $\begin{array}{c}1: 12: 00 \\
\text { PM }\end{array}$ & 1744 & 2035 \\
\hline $\begin{array}{c}1: 13: 00 \\
\text { PM }\end{array}$ & 1638 & 2242 \\
\hline $\begin{array}{c}1: 14: 00 \\
\text { PM }\end{array}$ & 1620 & 2227 \\
\hline $\begin{array}{c}1: 15: 00 \\
\text { PM }\end{array}$ & 1515 & 2124 \\
\hline $\begin{array}{c}1: 16: 00 \\
\text { PM }\end{array}$ & 1480 & 2038 \\
\hline $\begin{array}{c}1: 17: 00 \\
\text { PM }\end{array}$ & 1521 & 1886 \\
\hline $\begin{array}{c}1: 18: 00 \\
\text { PM }\end{array}$ & 1533 & 1918 \\
\hline $\begin{array}{c}1: 19: 00 \\
\text { PM }\end{array}$ & 1510 & 1940 \\
\hline $\begin{array}{c}1: 20: 00 \\
\text { PM }\end{array}$ & 1566 & 1943 \\
\hline $\begin{array}{c}1: 21: 00 \\
\text { PM }\end{array}$ & 1525 & 1923 \\
\hline $\begin{array}{c}1: 22: 00 \\
\text { PM }\end{array}$ & 1481 & 1868 \\
\hline $\begin{array}{c}1: 23: 00 \\
\text { PM }\end{array}$ & 1484 & 1845 \\
\hline $\begin{array}{c}1: 24: 00 \\
\text { PM }\end{array}$ & 1540 & 1775 \\
\hline $\begin{array}{c}1: 25: 00 \\
\text { PM }\end{array}$ & 1530 & 1721 \\
\hline $\begin{array}{c}1: 26: 00 \\
\text { PM }\end{array}$ & 1462 & 1700 \\
\hline $\begin{array}{c}1: 27: 00 \\
\text { PM }\end{array}$ & 1480 & 1686 \\
\hline $\begin{array}{c}1: 28: 00 \\
\text { PM }\end{array}$ & 1496 & 1651 \\
\hline $\begin{array}{c}1: 29: 00 \\
\text { PM }\end{array}$ & 1443 & 1659 \\
\hline
\end{tabular}

\begin{tabular}{|c|c|}
\hline \multicolumn{2}{|c|}{ 7-Dec (Cont.) } \\
\hline $\begin{array}{c}\text { Station } \\
1\end{array}$ & $\begin{array}{c}\text { Station } \\
2\end{array}$ \\
\hline 1511 & 2967 \\
\hline 1794 & 3035 \\
\hline 2237 & 4560 \\
\hline 2351 & 5120 \\
\hline 2010 & 2045 \\
\hline 1649 & 1763 \\
\hline 1671 & 1665 \\
\hline 1825 & 1617 \\
\hline 2145 & 1630 \\
\hline 1530 & 1762 \\
\hline 1457 & 2290 \\
\hline 1469 & 1797 \\
\hline 1471 & 2061 \\
\hline 1663 & 4610 \\
\hline 1564 & 4225 \\
\hline 1594 & 2947 \\
\hline 1768 & 2583 \\
\hline 1367 & 2986 \\
\hline 1749 & 3011 \\
\hline 2095 & 8232 \\
\hline 2433 & 8640 \\
\hline 2548 & 3065 \\
\hline 2917 & 2126 \\
\hline 3072 & 2162 \\
\hline 3296 & 2064 \\
\hline 3610 & 1840 \\
\hline 3824 & 2001 \\
\hline 4310 & 2316 \\
\hline 7805 & 2964 \\
\hline 4914 & 1963 \\
\hline
\end{tabular}




\begin{tabular}{|c|c|c|}
\hline \multirow[b]{2}{*}{ Time } & \multicolumn{2}{|c|}{ 4-Oct (Cont.) } \\
\hline & $\begin{array}{c}\text { Station } \\
1\end{array}$ & $\begin{array}{c}\text { Station } \\
2\end{array}$ \\
\hline $\begin{array}{c}1: 30: 00 \\
\text { PM }\end{array}$ & 1444 & 1640 \\
\hline $\begin{array}{c}1: 31: 00 \\
\text { PM }\end{array}$ & 1467 & 1620 \\
\hline $\begin{array}{c}1: 32: 00 \\
\text { PM }\end{array}$ & 1451 & 1593 \\
\hline $\begin{array}{c}1: 33: 00 \\
\text { PM }\end{array}$ & 1448 & 1599 \\
\hline $\begin{array}{c}1: 34: 00 \\
\text { PM }\end{array}$ & 1406 & 1603 \\
\hline $\begin{array}{c}1: 35: 00 \\
\text { PM }\end{array}$ & 1441 & 1583 \\
\hline $\begin{array}{c}1: 36: 00 \\
\text { PM }\end{array}$ & 1442 & 1597 \\
\hline $\begin{array}{c}1: 37: 00 \\
\text { PM }\end{array}$ & 1486 & 1595 \\
\hline $\begin{array}{c}1: 38: 00 \\
\text { PM }\end{array}$ & 1562 & 1602 \\
\hline $\begin{array}{c}1: 39: 00 \\
\text { PM }\end{array}$ & 1476 & 1602 \\
\hline $\begin{array}{c}1: 40: 00 \\
\text { PM }\end{array}$ & 1578 & 1600 \\
\hline $\begin{array}{c}1: 41: 00 \\
\text { PM }\end{array}$ & 1578 & 1600 \\
\hline $\begin{array}{c}1: 42: 00 \\
\text { PM }\end{array}$ & 1488 & 1598 \\
\hline $\begin{array}{c}1: 43: 00 \\
\text { PM }\end{array}$ & 1441 & 1595 \\
\hline $\begin{array}{c}1: 44: 00 \\
\text { PM }\end{array}$ & 1427 & 1581 \\
\hline $\begin{array}{c}1: 45: 00 \\
\text { PM }\end{array}$ & 1611 & 1513 \\
\hline $\begin{array}{c}1: 46: 00 \\
\text { PM }\end{array}$ & 1809 & 1428 \\
\hline $\begin{array}{c}1: 47: 00 \\
\text { PM }\end{array}$ & 1664 & 1303 \\
\hline $\begin{array}{c}1: 48: 00 \\
\text { PM }\end{array}$ & 2411 & 1158 \\
\hline $\begin{array}{c}1: 49: 00 \\
\text { PM }\end{array}$ & 3220 & 1151 \\
\hline $\begin{array}{c}1: 50: 00 \\
\text { PM }\end{array}$ & 2499 & 1230 \\
\hline $\begin{array}{c}1: 51: 00 \\
\text { PM }\end{array}$ & 1775 & 1227 \\
\hline $\begin{array}{c}1: 52: 00 \\
\text { PM }\end{array}$ & 1867 & 1225 \\
\hline $\begin{array}{c}1: 53: 00 \\
\text { PM }\end{array}$ & 1649 & 1235 \\
\hline $\begin{array}{c}1: 54: 00 \\
\text { PM }\end{array}$ & 3451 & 1249 \\
\hline $\begin{array}{c}1: 55: 00 \\
\text { PM }\end{array}$ & 2419 & 1256 \\
\hline $\begin{array}{c}1: 56: 00 \\
\text { PM }\end{array}$ & 1563 & 1270 \\
\hline $\begin{array}{c}1: 57: 00 \\
\text { PM }\end{array}$ & 1595 & 1281 \\
\hline $\begin{array}{c}1: 58: 00 \\
\text { PM }\end{array}$ & 1762 & 1269 \\
\hline $\begin{array}{c}1: 59: 00 \\
\text { PM }\end{array}$ & 3186 & 1269 \\
\hline
\end{tabular}

\begin{tabular}{|c|c|}
\hline \multicolumn{2}{|c|}{ 7-Dec (Cont.) } \\
\hline $\begin{array}{c}\text { Station } \\
1\end{array}$ & $\begin{array}{c}\text { Station } \\
2\end{array}$ \\
\hline 4663 & 1963 \\
\hline 5182 & 4821 \\
\hline 5683 & 4703 \\
\hline 5674 & 8852 \\
\hline 6161 & 3804 \\
\hline 6167 & 4242 \\
\hline 6358 & 3293 \\
\hline 6603 & 2409 \\
\hline 6985 & 2516 \\
\hline 13876 & 4263 \\
\hline 7530 & 6593 \\
\hline 7881 & 3309 \\
\hline 26686 & 2326 \\
\hline 9675 & 1599 \\
\hline 8189 & 1623 \\
\hline 7964 & 1913 \\
\hline 8685 & 1861 \\
\hline 7922 & 2266 \\
\hline 8002 & 2044 \\
\hline 11881 & 1530 \\
\hline 3725 & 1729 \\
\hline 1615 & 2028 \\
\hline 1635 & 1832 \\
\hline 1710 & 1712 \\
\hline 3171 & 1656 \\
\hline 1822 & 1652 \\
\hline 1566 & 1623 \\
\hline & \\
\hline & \\
\hline & \\
\hline & \\
\hline
\end{tabular}




\begin{tabular}{|c|c|c|}
\hline \multirow[b]{2}{*}{ Time } & \multicolumn{2}{|c|}{ 4-Oct (Cont.) } \\
\hline & $\begin{array}{c}\text { Station } \\
1\end{array}$ & $\begin{array}{c}\text { Station } \\
2\end{array}$ \\
\hline $\begin{array}{c}2: 00: 00 \\
\text { PM }\end{array}$ & 1626 & 1271 \\
\hline $\begin{array}{c}2: 01: 00 \\
\text { PM }\end{array}$ & 1557 & 1274 \\
\hline $\begin{array}{c}2: 02: 00 \\
\text { PM }\end{array}$ & 1520 & 1265 \\
\hline $\begin{array}{c}2: 03: 00 \\
\text { PM }\end{array}$ & 1496 & 1268 \\
\hline $\begin{array}{c}2: 04: 00 \\
\text { PM }\end{array}$ & 1514 & 1243 \\
\hline $\begin{array}{c}\text { 2:05:00 } \\
\text { PM }\end{array}$ & 1472 & 1214 \\
\hline $\begin{array}{c}\text { 2:06:00 } \\
\text { PM }\end{array}$ & 1488 & 1204 \\
\hline $\begin{array}{c}2: 07: 00 \\
\text { PM }\end{array}$ & 1461 & 1199 \\
\hline $\begin{array}{c}2: 08: 00 \\
\text { PM }\end{array}$ & 1484 & 1196 \\
\hline $\begin{array}{c}\text { 2:09:00 } \\
\text { PM }\end{array}$ & 1545 & 1217 \\
\hline $\begin{array}{c}2: 10: 00 \\
\text { PM }\end{array}$ & 1494 & 1229 \\
\hline $\begin{array}{c}2: 11: 00 \\
\text { PM }\end{array}$ & 1446 & 1223 \\
\hline $\begin{array}{c}2: 12: 00 \\
\text { PM }\end{array}$ & 1462 & 1194 \\
\hline $\begin{array}{c}2: 13: 00 \\
\text { PM }\end{array}$ & 1453 & 1183 \\
\hline $\begin{array}{c}2: 14: 00 \\
\text { PM }\end{array}$ & 1422 & 1191 \\
\hline $\begin{array}{c}2: 15: 00 \\
\text { PM }\end{array}$ & 1432 & 1187 \\
\hline $\begin{array}{c}2: 16: 00 \\
\text { PM }\end{array}$ & 2126 & 1170 \\
\hline $\begin{array}{c}2: 17: 00 \\
\text { PM }\end{array}$ & 1741 & 1161 \\
\hline $\begin{array}{c}2: 18: 00 \\
\text { PM }\end{array}$ & 1834 & 1136 \\
\hline $\begin{array}{c}2: 19: 00 \\
\text { PM }\end{array}$ & 1516 & 1120 \\
\hline $\begin{array}{c}2: 20: 00 \\
\text { PM }\end{array}$ & 1476 & 1126 \\
\hline $\begin{array}{c}2: 21: 00 \\
\text { PM }\end{array}$ & 1466 & 1122 \\
\hline $\begin{array}{c}2: 22: 00 \\
\text { PM }\end{array}$ & 1449 & 1120 \\
\hline $\begin{array}{c}2: 23: 00 \\
\text { PM }\end{array}$ & 1463 & 1109 \\
\hline $\begin{array}{c}2: 24: 00 \\
\text { PM }\end{array}$ & 1471 & 1091 \\
\hline $\begin{array}{c}2: 25: 00 \\
\text { PM }\end{array}$ & 1466 & 1096 \\
\hline $\begin{array}{c}2: 26: 00 \\
\text { PM }\end{array}$ & 1459 & 1098 \\
\hline $\begin{array}{c}2: 27: 00 \\
\text { PM }\end{array}$ & 1512 & 1084 \\
\hline $\begin{array}{c}2: 28: 00 \\
\text { PM }\end{array}$ & 1491 & 1079 \\
\hline $\begin{array}{c}2: 29: 00 \\
\text { PM }\end{array}$ & 1449 & 1081 \\
\hline
\end{tabular}




\begin{tabular}{|c|c|c|}
\cline { 2 - 3 } \multicolumn{1}{c|}{} & \multicolumn{2}{c|}{ 4-0ct (Cont.) } \\
\hline Time & $\begin{array}{c}\text { Station } \\
\mathbf{1}\end{array}$ & $\begin{array}{c}\text { Station } \\
\mathbf{2}\end{array}$ \\
\hline $\begin{array}{c}2: 30: 00 \\
\text { PM }\end{array}$ & 1488 & 1084 \\
\hline $\begin{array}{c}2: 31: 00 \\
\text { PM }\end{array}$ & 1472 & 1070 \\
\hline $\begin{array}{c}2: 32: 00 \\
\text { PM }\end{array}$ & 1555 & 1073 \\
\hline $\begin{array}{c}2: 33: 00 \\
\text { PM }\end{array}$ & 1586 & 1070 \\
\hline $\begin{array}{c}2: 34: 00 \\
\text { PM }\end{array}$ & 1555 & 1067 \\
\hline $\begin{array}{c}2: 35: 00 \\
\text { PM }\end{array}$ & 1517 & 1091 \\
\hline
\end{tabular}

